\title{
Cultural, Social and Political Dimensions of Non-European Societies: Case studies of selected societies in Asia and the Middle East
}

Edited by Joanna Marszałek-Kawa Jakub Zajączkowski 


\author{
Series \\ Asia-Pacific Library \\ Editor-in-Chief \\ Joanna Marszałek-Kawa
}

Secretary

Bartosz Ptotka

\begin{abstract}
The Editorial Board
Kamal M. Abdulla (Azerbaijan), Daulet L. Baideldinov (Kazakhstan), Marceli Burdelski (Poland), He Yaomin (China), Hassan A. Jamsheer (Poland), Vasyl Marchuk (Ukraine), Joanna Marszałek-Kawa (Poland), Miao Huashou (China), Vladimir I. Nifadiev (Kyrgyzstan), Ewa Oziewicz (Poland), Zdzisław Puślecki (Poland), Akmal Saidov (Uzbekistan), Grażyna Strnad (Poland), Peter Vorel (Czech Republic)
\end{abstract}

\author{
Reviewers \\ Professor Tadeusz Dmochowski \\ Professor Marian Kowalewski \\ Publishing editor: Daniel Kawa \\ Technical editing: Ryszard Kurasz \\ Proofreading: Team \\ Cover design: Krzysztof Galus
}

(c) Copyright by Wydawnictwo Adam Marszałek

All rights reserved. The book you have purchased is the work of the author and the publisher. No part of it may be reproduced in any manner whatsoever without permission in writing from the copyright owner. In case of brief quotations of the work do not change the contents and make sure to note whose it is

Toruń 2020

\title{
ISBN 978-83-8180-465-3
}

The $7^{\text {th }}$ International Asian Congress "Building the Future of the State: Tradition, Reality, Progress" - a task co-financed under contract no. DNK/SP/466246/2020 from the Ministry of Science and Education funds allocated to the dissemination of science

Sales Department: tel. +48 5666422 35, marketing@marszalek.com.pl

Adam Marszałek Publishing House, ul. Lubicka 44, 87-100 Toruń tel. +48 5666422 35, e-mail: info@marszalek.com.pl, www.marszalek.com.pl Printing House, ul. Warszawska 54, 87-148 Łysomice, tel. +48 566783478 


\section{Table of Contents}

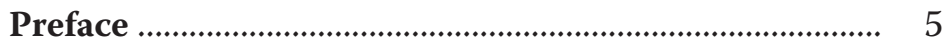

\section{Lukasz Danel}

The Changing Role of the Commonwealth

as an Element in India's Global Positioning

\section{Marian Tadeusz Mencel}

The Socio-political Impact of the May 4 Movement on Chinese Nationalism, Civil Society and Rejection of the Confucian Tradition

\section{Beata Pietkiewicz-Pareek}

Remote Education in India during the COVID-19

Pandemic

\section{Stanisław Juszczyk}

A Comparative Analysis of Education Cultures in the Republic of Korea and Poland

\section{Katarzyna Chałubińska-Jentkiewicz}

Internet Access Rights in Central Asian Countries 


\section{Paulina Stanik}

Martial Race Theory in the Representation

of the South Asian Other in Polish World War II

Accounts

Marzena Toumi, Aleksander Olech

Saudi Cybersecurity Strategy

Edyta Wolny-Abouelwafa

Representations of Egyptian Society in Egyptian

Patriotic Video Clips (2018-2020)

\section{Magdalena Kubarek}

Critical Representation of the Present in the Historical

Novel in Egypt: Selected Aspects 


\section{Preface}

After the end of the Cold War, non-European countries, both in Asia (most of them) and some in the Middle East, were characterized by high economic growth. As they narrowed the gap with the countries of the North in the material realm, these countries, especially at the beginning of the $21^{\text {st }}$ century, increasingly began to emphasize their achievements in the non-material sphere. After all, these countries have rich cultural, civilizational and historical traditions. Given the important roles of cultural, civilizational, educational and social conditions in shaping contemporary societies in non-European regions, it is vital to research how these factors are influencing the countries of Asia and the Middle East.

This is because social and cultural conditions, traditions and values determine the specificity and identity of these dynamically developing countries in Asia and the Middle East. The interdependence of social phenomena and their role in affecting political and economic processes have contributed to the study of selected states in these regions. International relations researchers, both from Western and non-European universities, began to emphasize in particular the contribution of non-European concepts to the discipline of international relations. ${ }^{1}$ Political science researchers

1 See more: J. Zajączkowski, M.F. Gawrycki, A. Bógdał-Brzezińska (eds.), Re-Wizje i Re-Orientacje: Myśl pozaeuropejska w nauce o stosunkach międzynarodowych, Warszawa 2012 (English edition: Re-Visions and 
started to pay attention to how historical and cultural conditions have influenced the identity of these states.

Cultural and historical determinants, therefore, are of key importance in contemporary non-European countries. Without understanding them, a comprehensive analysis of domestic and foreign policy is impossible. On the one hand, dynamic changes, economic reforms, modernization and, on the other hand, tradition, continuity, and values require the states of the region to constantly adapt and modify both domestic and foreign policies.

Taking into account the above assumptions, this publication offers a multidimensional analysis of the importance of cultural, historical and identity determinants for domestic and foreign policies. The publication focuses primarily on the issues of internal policy, which results from the fact that knowledge about the internal and historical conditions of non-European countries is still limited.

At the same time, the publication has no ambition to fulfill this task in its entirety. The editors of the volume are also aware not only of the differences between individual regions, i.e. Asia and the Middle East, but also of intra-regional diversity. The intention of the publication is therefore to outline the issues, to provide an introduction to the selected issues, and above all, to highlight the importance of cultural and historical factors in research on contemporary non-European countries.

The structure of the book has been determined by this goal. In terms of the subject matter, it can be divided into two parts. The first, consisting of 6 articles, analyzes political, cultural and educational issues in selected Asian counStudies, New Delhi-London-New York-Sydney: Bloomsbury 2014). 
tries. The second part, which consists of 3 articles, is dedicated to two case studies of Egypt and Saudi Arabia.

The scope of the book includes such issues as: the role of historical heritage in shaping domestic and foreign policy, the education system and its role in the state as well as cybersecurity.

Łukasz Danel, in his article on the role of the Commonwealth of Nations in India's foreign policy, emphasizes that since 2014 India has been increasingly interested in a more active policy within its framework. The researcher argues that the Commonwealth of Nations may turn out to be a significant instrument for India in the context of competition with other powers and countries on a global scale. He also emphasizes that, in the post-Brexit eera, Great Britain may become one of India's most important allies, as London will be forced to strengthen its position outside Europe. A strong and stable Commonwealth of Nations may, as the author emphasizes, turn out to be a key instrument serving this purpose.

Marian Tadeusz Mencel analyzes the significance of the May 4th Movement for shaping internal social relations and changes in the Chinese socio-political space. The scope of the analysis is determined by factors including internal relations and social changes in China after the overthrow of feudal authoritarianism and the increase in social awareness, interest in socialism and communism, as well as the rise of nationalism together with the rejection of Confucian traditions. The researcher points out that the significance of the May $4^{\text {th }}$ Movement goes far beyond the Marxist ideological and doctrinal approach. This is evidenced by contemporary developments in China, where the main actor is, similarly as in 1919, the Chinese intelligentsia. 
Beata Pietkiewicz-Pareek discusses distance learning in India during the Covid-19 pandemic. The researcher focuses primarily on the poorest regions of India. She presents the procedures implemented by the authorities and their operationalization.

Stanisław Juszczyk, referring to the Socratic and Confucian perspective of education, discusses and compares the culture of education in Poland and in the Republic of Korea. The author uses the hermeneutic method and literary interpretation to analyze this research problem. As a result, the study is cross-cultural in nature and concerns the main features of contemporary education in Poland and in the Republic of Korea.

Katarzyna Chałubińska-Jentkiewicz discusses the legal conditions and government policy in Central Asian countries relating to the right of access to the Internet. The researcher emphasizes that this area of digital media should be perceived in the context of important public tasks and the principles of network regulation.

Paulina Stanik, referring to the nineteenth-century martial race theory, examines whether the influence of this ideology is reflected in the Polish perception of Indians and Gurkhas during World War II. The researcher refers to a collection of fragments of Polish personal narratives from this period. The author points out that elements of the imperial discourse of martial races also shaped the perception of Polish soldiers about Indians and Gurkhas.

Marzena Toumi and Aleksander Olech take up the issue of the evolution of cybersecurity strategies implemented by the Saudi Arabian authorities. They note that in recent years the government of this country has been allocating significant resources to the development of security and 
regional administration, including cybersecurity. For this purpose, among others in 2020, over USD 27 million was spent within the state budget. The funds are intended for the expansion of digital infrastructure and the modernization of information security management. Development and training programs have also been created for the citizens of Saudi Arabia. The authors also discuss further institutionalization of cybersecurity strategy, as evidenced, inter alia, by the establishment in 2018 of the Saudi Federation for Cybersecurity, Programming and Drones. This new institution aims to stimulate technological innovation and create career opportunities for the citizens of Saudi Arabia. The authors emphasize that the above actions meant that in just two years, from 2017 to 2019, Saudi Arabia moved from 46th to 13th place in the ranking of the International Telecommunication Union known as Global Cybersecurity Index.

Edyta Wolny-Abouelwafa assesses the importance of patriotic songs in creating or strengthening the attitudes of patriotism in the case of Egypt. The researcher emphasizes that the importance of music in this context is often underestimated in research. She points out that undertaking research on this issue will help understanding of the vision of the state and society represented by selected artists, who significantly shape social feelings and perceptions in this respect. The author referred in her research to three case studies of music videos of patriotic songs from 2018 and 2020. The chapter constitutes an attempt to answer two main questions: what perception of Egyptian society is presented in the music videos and to what extent this perception reflects the reality of contemporary Egyptian society.

Magdalena Kubarek, referring to selected historical novels, demonstrates that their authors, regardless of various 
literary trends, made history and stories about the past an effective tool for a critical assessment of the present. For this reason, as the author points out, the historical novel is an important element in the discourse of Arab intellectuals who aim to diagnose and define the most important problems of the Arab world.

The authors of the texts in their publications drew on both primary and secondary sources. In their research, the majority of references were made to qualitative methods, discourse analysis and case studies. Part of the research is based on empirical research and interviews.

This collection thus aims to expand the literature in the field of non-European issues. This is important for several reasons. Firstly, since the 1990s, studies on contemporary non-European countries and regions as well as regional studies, as part of the discipline of international relations, have been developing in Poland. There are also more and more courses and research on the specifics of contemporary business and politics in Asia, the Middle East and other non-European regions. Despite these development, in Poland, and also in Europe, we still have a deficit of knowledge of contemporary Asia and the Middle East, especially in the context of social changes and the importance of culture for contemporary business and politics. Paying attention to these issues will enable a better understanding of the specificity of Asian and Middle East countries, and more broadly, of non-European areas.

Joanna Marszałek-Kawa Jakub Zajączkowski 


\section{Eukasz Danel}

Cracow University of Economics

ORCID ID: https://orcid.org/0000-0001-9715-3377

\section{The Changing Role of the Commonwealth as an Element in India's Global Positioning}

\section{Introduction}

India's ties to the Commonwealth are very long, even longer than the independence it gained in 1947. While still a British colony, India, which was considered the "Jewel in the Crown" for the British Empire due to its location and resources, participated, to a limited extent, in the imperial conferences the British Commonwealth of Nations - an international organization founded in 1931.

Like many other former British colonies, Independent India chose to maintain these unique ties with London, thus intending to safeguard its own, widely understood interests in the first place. However, the decision to stay in the Commonwealth was not obvious. It was influenced by several factors and purely political calculations of the then political authorities of that country. Thanks to membership in the Commonwealth, this young democracy managed to achieve various goals in the international arena, which indirectly also made it possible to build a strong, independent state. However, for many decades, with a few exceptions only, the Commonwealth has not been treated by the Indian political leaders as the country's leading foreign policy partner. 
Successive Indian governments did not give the cultivation of good relations with London any special priority. On the contrary - for a long time, this organization was rather perceived by India as a relic of colonial times devoid of political and economic importance.

In recent years, however, this situation has changed dramatically, as they have shown a growing interest in the Commonwealth of Nations on the part of the Indian political leadership. Narendra Modi, who has been the prime minister of India since 2014, not only significantly redefined the country's attitude toward the Commonwealth but also clearly changed the rhetoric of the Indian political elite concerning this international organization, which for India seems no longer to be a relic of the past, but an essential tool in implementing its global goals.

The paper addresses the question of what lies behind the mentioned change in India's attitude toward the Commonwealth and reflects on how India can use this international organization to build its position - not only in South Asia or on the entire Asian continent, but in a global scale.

The author will try to prove the thesis that, for various reasons, for today's India, the importance of the Commonwealth may turn out to be crucial in the context of the competition with other global players. Furthermore, unexpectedly, one of India's key allies may soon be the former "emperor", i.e., the United Kingdom of Great Britain and Northern Ireland. After leaving the European Union (the so-called Brexit), this country is forced, at least in a sense, to redefine its goals in foreign policy in order to maintain its international position. It also includes, and perhaps even above all, searching for new partners and gaining new allies - both political and economic. Therefore, strengthening 
the Commonwealth is in the interest of the United Kingdom, for which India may soon turn out to be much more important than the United Kingdom for India. To address the research problem, resolve the outlined dilemmas, and prove the mentioned theses, the author uses the historical and content analysis methods.

\section{The Significance of the Commonwealth and Specificity of Its Asian Part}

According to the Declaration of Commonwealth Principles, which was issued by the Commonwealth Heads of Government Meeting (CHOGM) at their summit in Singapore in 1971, the Commonwealth is a "voluntary association of independent sovereign states, each responsible for its own policies, consulting and co-operating in the common interests of their peoples and in the promotion of international

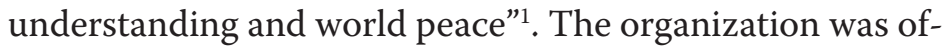
ficially founded in 1931 as the British Commonwealth of Nations - the famous Statute of Westminster gave formal and legal recognition to the sovereignty of the British dominions. It turned out to be a milestone in the functioning of the British Empire, which over time was becoming politically weaker and therefore more prone to internal instability ${ }^{2}$. In 1949 the London Declaration was signed,

1 https://thecommonwealth.org/declaration-commonwealth-principles [access: 20.01.2021].

2 To explore the history of the British Empire, see for example: N. Fergusson, Empire. How Britain Made the Modern World, London 2003; T. Lloyd, Empire. The history of the British Empire, London-New York 2001; H.D. Hall, Commonwealth. A History of the British Commonwealth of Nations, New York 1971. 
which marked the birth of the modern Commonwealth of Nations under its current name - the adjective "British" was dropped from the name, and the provision of allegiance to the Crown was removed from the statute (the British monarch, however, remained the head of the Commonwealth). The London Declaration also stressed its members' freedom and equality - both in their relationship to the Head of the Commonwealth (defined as a "free association of independent nations") and in their cooperative "pursuit of peace, liberty, and progress"3.

For many years the Commonwealth functioned based on various quasi-constitutional documents, like for example, the mentioned Singapore Declaration (1971), the Harare Declaration (1991) or the Edinburgh Declaration (1997) strengthened by the Kampala Communiqué (2007) or Kampala Declaration on Transforming Societies to Achieve Political, Economic and Human Development (2007). Finally, in 2012, the Commonwealth Charter was adopted, which committed all the member states to 16 values and principles. These are: democracy, human rights, international peace and security, tolerance, respect and understanding, freedom of expression, separation of powers, the rule of law, good governance, sustainable development, protecting the environment, access to health, education, food, and shelter, gender equality, the importance of young people in the Commonwealth, recognition of the needs of the small states, recognition of the needs of the vulnerable states, and the role of civil society ${ }^{4}$. These core values and principles

3 London Declaration, Issued at the Commonwealth Prime Ministers Meeting, London, April 22-27, 1949, https://thecommonwealth.org/ sites/default/files/inline/London-Declaration.pdf [access: 12.01.2021].

4 Charter of the Commonwealth, Signed by Her Majesty Queen Eliz- 
can be enforced with regard to the member states of the Commonwealth - for failing to respect them, they may be either suspended or even expelled from the organization.

There are 54 member states of the Commonwealth located in almost all parts of the world - in Europe (3), Africa (19), Asia (8), the Americas (13), and the Pacific (11). These countries are very diverse in terms of their size (32 are classified as small states, on the other hand, Canada, India, or Australia are among the world's largest countries), the level of economic development (both the richest and poorest countries) as well as in terms of many other criteria. The Commonwealth's potential becomes particularly apparent when we realize that it is a home to 2.4 billion people, which constitutes more or less one-third of the global population. The vast majority of the Commonwealth member states are former British colonies or dependencies that decided to remain in close political and economic relations with the United Kingdom. Out of 54 members, 16 are the so-called Commonwealth realms ${ }^{5}, 5$ are monarchies ruled by their monarchs (Brunei Darussalam, Swaziland, Lesotho, Malaysia, and Tonga), and the remaining 34 are republics ${ }^{6}$.

For many reasons, eight Asian countries seem to be an essential part of the Commonwealth. These are Bangladesh, Brunei Darussalam, India, Malaysia, Maldives, Pakistan,

abeth II, Head of the Commonwealth, Commonwealth Day 2013, https:// thecommonwealth.org/sites/default/files/page/documents/CharteroftheCommonwealth.pdf [access: 12.01.2021].

5 It means that they remain in the personal union with the United Kingdom. The British monarch (at the same time the Head of the Commonwealth) is, therefore, also the head of state of the remaining 15 Commonwealth realms.

6 https://thecommonwealth.org/member-countries [access: 12.01.2021]. 
Singapore, and Sri Lanka. All of them are geographically located either in South Asia or in South-East Asia. The significance of the Asian part of the Commonwealth is directly related primarily to its population size - around 70\% of the Commonwealth's citizens live in South Asia, which undoubtedly affects the economic attractiveness of this area. From the political and constitutional perspective, there are no Commonwealth realms in Asia. However, Brunei Darussalam and Malaysia are monarchies with their own monarchs - the former is a sultanate, the latter - a kingdom. The six remaining ones are republics - most of them parliamentary ones, and only Sri Lanka may be classified as an example of a presidential republic where the president is at the same time the head of government ${ }^{7}$.

Politically, the Asian part of the Commonwealth is not very stable. Evidence of this is provided by even a cursory analysis of the various indicators of democracy. It can even be argued that not all Asian members of the Commonwealth meet all the membership criteria - especially when we consider the level of democracy, the protection of human rights, or the compliance of the government policy with the rule of law. According to the latest report published by the Freedom House, only India is classified as a 'free' country, six countries are classified as 'partly free', and Brunei Darussalam is even classified as a 'not free' country ${ }^{8}$. Moreover, it is this country that one may have the most severe reserva-

7 Ł. Danel, The Asian Part of the Commonwealth - the Problematic Case of the Maldives, [in:] Peculiarities of China's Politics and Culture, eds. J. Marszałek-Kawa, K. Rezmer-Płotka, Torun 2019, pp. 157-158.

8 Freedom in the World 2020. A Leaderless Struggle for Democracy, Freedom House, https://freedomhouse.org/sites/default/files/2020-02/ FIW_2020_REPORT_BOOKLET_Final.pdf [access: 12.01.2021]. 
tions and doubts when it comes to meeting the membership criteria of the Commonwealth'.

So, India - also in the light of other indexes and barometers of democracy - is the only fully democratic state in the Asian part of the Commonwealth. This seventh-largest country by land has more than 1.3 billion inhabitants, making it the second-most populous country and the most populous democracy in the whole world. India was the first republic in the Commonwealth, which paved the way for other republics to apply for membership in this organization. The history of India's membership in the Commonwealth is full of meaningful events, which also tells us something about the strategy of the current Indian government.

\section{India and the Commonwealth}

In studies on the history of India's membership in the Commonwealth, prime minister Jawaharlal Nehru's memorable words are often recalled: "Under no conceivable circumstances is India going to remain in the British Commonwealth whatever the consequences. This is not a question for me to decide or for any few of us to decide. Any attempt to remain in the Commonwealth will sweep away those who propose it and might bring about major trouble in India" ${ }^{10}$. If so, the question becomes - what happened, and under what circumstances India eventually became a Commonwealth member?

Long before gaining its independence, so yet as part of the British Empire, India participated in colonial and impe-

9 Ł. Danel, The Asian Part, op.cit., p. 158.

10 R.J. Moore, Mountbatten, India, and the Commonwealth, „Journal of Commonwealth \& Comparative Politics" 1981, vol. 19, no. 1, p. 13. 
rial conferences held from time to time since the 1880s. Until 1917, however, India had not had the right of direct participation in these events since this privilege was reserved to those self-governing parts of the empire that enjoyed the status of dominion. When the Statute of Westminster gave legal recognition to the sovereignty of the British dominions (Canada, Australia, New Zealand, South Africa, Irish Free State, and Newfoundland) and emphasized their equal status, India once again could have felt like a second-category member.

The debate on whether India should become the British dominion - to better protect its political and economic interests - has been going on since the 1920s. The arguments of the enthusiasts of such a step (Mahatma Gandhi also supported this idea) clashed with its opponents, whose main representatives were Jawaharlal Nehru and Subhas Chandra Bose. These left-wing members of the Indian National Congress strove for the independence of India and the establishment of a republic, which - in their opinion - should sever all ties with the British Empire. Because the British were also in no hurry to offer India the status of a dominion (or to hand over more power to Indian politicians), the fight for India's complete independence became the official and overarching goal of the Congress. This unequivocal position of Congress persisted for a very long time, and that is why in 1947, Nehru used the memorable, quoted words ${ }^{11}$.

However, everything changed dramatically when the famous Mountbatten Plan ${ }^{12}$ was announced in May 1947.

11 S. Daniyal, History revisited: Why did Nehru give up his bitter opposition to the Commonwealth and join in 1947?, Scroll.in, April 24, 2018, https://scroll.in/article/876483/history-revisited-why-did-nehrugive-up-his-bitter-opposition-to-the-commonwealth-and-join-in-1947 [access: 12.01.2021].

12 The plan was named after Louis Mountbatten - the British states- 
According to this plan, British India was supposed to be partitioned into India and Pakistan's two new independent dominions. Faced with the need for a quick transfer of power in India, escalating social unrest, and the growing position of the Muslim League (manly in Bengal in Punjab), the then political leaders of India realized that the process of taking power from the British would run much more smoothly if India became the British dominion, and not a newly-established republic that would be unstable and full of internal tensions right from its birth. India needed a strong central authority at this time and under these specific circumstances to ensure internal stability ${ }^{13}$. That is why on August 15, 1947, when India finally became independent, it remained in the Commonwealth as the British dominion, with the British monarch as its head of state. It only changed in 1950, when India announced its transformation into a parliamentary republic which meant that King George VI ceased to be India's head of state ${ }^{14}$.

For the Commonwealth to have a republic as its member was a completely new challenge, so the membership rules had to be adjusted to these new circumstances. As mentioned earlier, India paved the way for other newly independent republics, located predominantly in Asia, Africa, the Pacific, and the Caribbean, to apply for membership. On the other hand, from India's point of view, the decision to remain in the Commonwealth seemed to be the only right one. It has

man, the last Viceroy of India and the first governor-general of independent India.

13 R.J. Moore, Mountbatten, India..., op.cit., p. 25.

14 For a detailed description of the events that led to India's accession to the Commonwealth of Nations see for example: B. Kreling, India and the Commonwealth: A Symbiotic Relationship?, "The Round Table" 2009, vol. 98, no. 400, pp. 49-66. 
brought no losses to India. On the contrary, it enabled this young democracy to achieve a certain level of internal stabilization and become a starting point for India to articulate and pursue its goals in foreign policy. Even though some strains appeared in relations with the Commonwealth (e.g., the Suez Crisis or the conflict over Kashmir), until his death in 1964, Jawaharlal Nehru, the first prime minister of independent India, was convinced that he had made the right decision.

Over the decades that followed, India's attitude to the Commonwealth oscillated somewhere between indifference and relative interest, although - simplifying a bit - it should be emphasized that successive Indian governments were not particularly interested in Commonwealth affairs. All successive prime ministers of this country attended most of the biennial Commonwealth Heads of Government Meetings (CHOGM). One of them was even hosted by then prime minister Indira Gandhi in New Delhi in $1983^{15}$. Irrespective of that, both Indian politicians and the Indians themselves for a long time viewed the Commonwealth more as a relic of its colonial past, devoid of political and economic importance, than a key partner in India's foreign policy. India's contributions to the Commonwealth's objectives were focused on two areas - the promotion of trade and development cooperation among its members and, secondly, the counteracting the illegal overthrow of democratically elected governments in some member states ${ }^{16}$.

15 As for other important events, India hosted the annual Commonwealth Parliamentary Association Conference in 1957, 1975, 1991, and 2007, as well as the Conference of Commonwealth Speakers and Presiding Officers in 2010. In the arena of sports, India hosted inter alia the Commonwealth Youth Games in 2008 and the XIX Commonwealth Games in 2010.

16 C.S.R. Murthy, India and the Commonwealth: Redirecting 
What is more, between 2011 and 2015, three times in a row, India's prime ministers sent someone else to the CHOGM summits - this was officially done each time for some good reason, though it was more of an excuse. In the case of prime minister Manmohan Singh, it happened twice (in 2011 and 2013), and in 2015, shortly after taking office, the current prime minister Narendra Modi also sent a replacement to the $24^{\text {th }} \mathrm{CHOGM}$ summit. All this happened even though in 2008-2016, for two terms in a row, Kamalesh Sharma, an Indian politician, and diplomat, served as the Secretary General of the Commonwealth of Nations.

In recent years, however, something has changed. First of all, India itself has changed significantly, but it is impossible not to notice the change in the attitude of the political leaders of this country, mainly prime minister Modi, to the Commonwealth of Nations.

\section{The Commonwealth as a Means of Building India's Global Position}

When visiting India in 2017, Prince Charles extended an invitation, on behalf of Queen Elizabeth II, to prime minister Narendra Modi to the $25^{\text {th }}$ CHOGM summit, which was about to be held in London on April 19-20, 2018. The participation of the Indian prime minister in this event, for the first time in almost ten years, was interpreted as a new opening in the relations between this country and the Commonwealth. According to many commentators and political analysts, the intention of this emerging world power at the

the Relationship, Carnegie India, April 11, 2018, https://carnegieindia.org/2018/04/11/india-and-commonwealth-redirecting-relationship-pub-76054 [access: 19.01.2021]. 
time was to demonstrate its willingness to play a far more important role in this organization and perhaps even to lead it.

The first question that can be asked is whether the Commonwealth needs new leadership at all. One may get the impression that it does because, for a long time, this organization has suffered from a lack of dynamism and a lack of ideas on how it should adapt to the changing global reality. One of the reasons for this is undoubtedly the lack of strong leadership - it is even said that the Commonwealth "has become nobody's Commonwealth" ${ }^{17}$. So, can India become such a leader? It seems that a country with $60 \%$ of the Commonwealth's population (and additionally a large number of Indians scattered around other member states) and which is involved in about a quarter of intra-Commonwealth trade, is a natural candidate to play such a role. In this way, India could serve the entire organization to become a significant player in global politics ${ }^{18}$. Finally, given its regional and global aspirations, India could "use" the Commonwealth to strengthen its position and importance on the international stage.

The fact is that the current government of India, led by Narendra Modi, has changed its attitude toward the Commonwealth - the rhetoric about the relic of colonialism devoid of political and economic importance has in recent years been replaced with rhetoric about the prospects of Indian leadership in this organization. The questions become - what lies behind this shift in India's perception of

17 K. Srinivasan, Nobody's Commonwealth? The Commonwealth in Britain's Post-Imperial Adjustment, „Commonwealth \& Comparative Politics" 2006, vol. 44, no. 2.

18 C.S.R. Murthy, India and the Commonwealth..., op.cit. 
the Commonwealth, and what benefits would the potential leadership of this organization bring to India? Rahul RoyChaudhury, the Senior Fellow for South Asia in the International Institute for Strategic Studies, highlights five main factors trying to address questions like that ${ }^{19}$.

First of all, the size of the Commonwealth, the fact that it comprises 54 different countries located in almost all parts of the world, makes it an attractive arena for a rising power like India with growing economic interests to strengthen bilateral economic ties with all these countries. It is crucial from a global perspective and in view of the more regional goals of India's foreign and security policy, including its close neighborhood and the Indian Ocean ${ }^{20}$. For subregional and regional cooperation India also uses its membership in other organizations, institutions, and more or less formal bodies. In this context, one can mention, for example, BRICS, the G20, or the Shanghai Cooperation Organization (SCO). It is also a party to many regional initiatives such as the South Asian Association for Regional Cooperation (SAARC), the Bay of Bengal Initiative for Multi-Sectoral Technical and Economic Cooperation (BIMSTEC), or the Indian Ocean Rim Association (IORA). However, the potential of these organizations cannot be compared to the natural potential of the Commonwealth. The reformed or redesigned Commonwealth could even become some kind of platform of closer subregional cooperation, for example,

19 R. Roy-Chaudhury, India's new political interest in the Commonwealth, The International Institute for Strategic Studies, April 17, 2018, https://www.iiss.org/blogs/analysis/2018/04/india-interest-commonwealth [access: 19.01.2021].

20 Ibidem. 
between the Asia Pacific and African countries ${ }^{21}$. All interested parties would feel the benefits of such cooperation. At the same time, India could additionally become the patron of such initiatives and their natural leader, which would be reflected in the increase in India's global position.

The second factor is associated with the growing importance of small states for India's foreign policy. As mentioned earlier in the article, as many as 32 Commonwealth member states (approximately 60\%) are classified as small states with fewer than 1.5 million people. In the vast majority of these states, they do not maintain permanent diplomatic missions abroad (so also in India) but use forums of international organizations such as the United Nations (UN) or the Commonwealth for diplomatic purposes. For many of them, the latter constitutes the main channel of diplomatic communication. By far, small states have been more neglected than appreciated by India. However, this perception must change for a country with global ambitions since these small states may provide significant opportunities for India in terms of its economic and security policies. Moreover, their potential support might be handy for India whenever the principle of "one country, one vote" applies in multilateral cooperation forums ${ }^{22}$.

Thirdly, as part of the general trends related to shifting the center of political and economic life to the East and the South, South-South cooperation among developing states has recently gained popularity, replacing the traditional model of North-South cooperation. Therefore, many of the Commonwealth member states are eager to cooperate not

21 C.S.R. Murthy, India and the Commonwealth..., op.cit.

22 R. Roy-Chaudhury, India's new political interest..., op.cit. 
with the former powers or superpowers but with the emerging powers ${ }^{23}$. India is potentially the most preferred partner for them. After overtaking the United Kingdom in 2018, the Indian economy is today the largest in the Commonwealth and at the same time the fifth largest economy in the world. Being part of the same family of states, many small island states of the Pacific and the Caribbean may also benefit from India's expertise and experiences.

The importance of the Commonwealth for India also results from a significant Indian diaspora in practically every member state of this organization. For the Bharatiya Janata Party and prime minister Narendra Modi personally (unlike for his predecessor from the Indian National Congress), the status and rights of Indians living abroad have become an important political issue to deal with. Last but not least the regional (in a way - also global) rivalry with China, for which the Commonwealth is out of reach. It makes it relatively easy for India to have many allies on its side, both in the context of territorial disputes with China (and with Pakistan, which in turn is China's ally) and the neutralization of its influence in South Asia and the Indian Ocean ${ }^{24}$.

\section{The United Kingdom After Brexit - India's Unexpected} Ally

On June 25, 2016, in a nationwide referendum, the British decided to leave the European Union after almost 50 years of membership in the European Communities (renamed the European Union in 1993). This decision triggered a long

23 Ibidem.

24 Ibidem. 
process of leaving the EU but finally, after the transition period, which lasted until December 31, 2020, Brexit became a reality. The consequences of this step are still unknown. However, there is no doubt that the United Kingdom found itself - at its own wish - in a completely new international situation and is now forced to redefine its most important foreign policy goals.

It is worth remembering that after World War II, uniting Europe was not a priority for the United Kingdom when it comes to political and economic cooperation. This role was reserved for the United States (famous "special relationship") and for what was left of the British Empire, i.e., the Commonwealth of Nations. That is why at the beginning of the 1950s, prime minister Winston Churchill did not express any interest in the UK's accession to the first European Communities that were then established. However, when in the early 1970s, the United Kingdom finally turned to united Europe, it downgraded the Commonwealth in its foreign policy naturally.

However, today the membership of the United Kingdom in the European Union is over, so we may expect the British, bearing in mind the uncertainty caused by its decision to quit the EU, to try to revive the Commonwealth in order to create a new window to the world from it. In the more conservative part of British society, there is still some nostalgia for the British Empire, which means that currently, the Commonwealth may be perceived even as an alternative to the European Union when it comes to safeguarding the UK's economy and trade interests. If so, the post-Brexit reality constitutes some kind of opportunity for the United Kingdom and India to cooperate in remapping the Commonwealth so that it brings positive results for both parties. 
The strengthened partnership between the United Kingdom and India looks inevitable. It seems likely that for the new, post-Brexit United Kingdom, India could become one of the main economic partners and a natural new leader of the Commonwealth.

Britain's hopes of reviving the Commonwealth are based on a simple calculation - being part of the EU, roughly half of British trade took place inside the bloc, while only around $10 \%$ was within the Commonwealth. Now, the United Kingdom will not enjoy the benefits of the European single market to such an extent. On the other hand, it regained the freedom and flexibility to individually shape its trade agreements with other countries without being constrained by EU regulations. Therefore, it will do everything to use this opportunity, primarily to compensate for the losses resulting from Brexit. Furthermore, India - with its economic and demographic potential - might turn out to be the key to success for the United Kingdom. While the British economy is shrinking, the Indian economy is booming - according to the International Monetary Fund, by 2050, it is expected to become the world's second-largest economy. While the British population is aging, India is expected to become the world's most populous country by 2024. These are just some of the arguments proving the thesis that Brexit has led to a situation in which India can play a significant role in the new mosaic of British global interests ${ }^{25}$.

Sometimes one might get the impression that in the bilateral relationship between the UK and India, the roles have

25 R. Bahl, India's best post-Brexit bet is the "zoomie" Commonwealth, Bloomberg Quint Opinion, September 20, 2019, https://www. bloombergquint.com/opinion/indias-best-post-brexit-bet-is-the-zombie-commonwealth, [access: 29.01.2021]. 
recently been completely reversed - in the past, the United Kingdom was essential to India (but not the other way around), and today India is vital to United Kingdom (but not the other way around). This thesis is a bit exaggerated, but it nevertheless reflects quite well a significant change that has taken place in global politics.

\section{Conclusions}

The Commonwealth of Nations is the world's second-largest inter-governmental organization by population behind the United Nations. With its great demographic and economic potential, India seems to be its most apparent future leader who will take responsibility to revive it and make it one of the most important players in the multipolar world. First of all, that would be in the interest of the Commonwealth members themselves because they could influence the shaping of the global order. After all, India has much to share with others and can serve as a role model in many ways. In this context, one can mention, for example, the promotion of democracy, good governance, or the rule of law. Even though for many small states, it is still the United Nations that constitutes the natural forum for a multilateral cooperation, the Commonwealth may also play a crucial role in addressing many issues and common concerns on relevant international issues. It is distinguished from other organizations by its style of functioning that is predominantly based on consensus-building, informality, and goodwill ${ }^{26}$.

26 India and the Commonwealth, Ministry of External Affairs (UNP Division), August 2011, https://mea.gov.in/Portal/ForeignRelation/commonwealth-august-2011.pdf [access: 29.01.2021]. 
Above all, the beneficiary of such a situation would be India, which has been showing ever-greater global ambitions for a long time. It looks like a typical win-win situation, and India itself does not have much to lose. Prime minister Narendra Modi seems to be aware of this. Many arguments prove the thesis that for today's India, the importance of the Commonwealth may turn out to be crucial in the competition with other global players. Most of such arguments have been listed and analyzed in this paper starting from the size of the Commonwealth, through the growing importance of small states for India's foreign policy, the overall growing preference for South-South cooperation, the possibility to take care of the sizable Indian diaspora abroad and ending with the course of future rivalry with China - another global player, but the one for whom any access to the Commonwealth is not possible.

The Commonwealth, as a truly global forum, seems to be an excellent opportunity for India to show its strength and to demonstrate its leadership abilities. Unexpectedly, it has recently gained an important ally for whom the withdrawal from the European Union means uncertainty of tomorrow and, consequently, the need to strengthen the Commonwealth. And it seems that probably only India can achieve this goal.

\section{Bibliography}

Bahl R., India's best post-Brexit bet is the "zoomie" Commonwealth, Bloomberg Quint Opinion, September 20, 2019, https://www.bloombergquint.com/opinion/indias-bestpost-brexit-bet-is-the-zombie-commonwealth. 
Charter of the Commonwealth, Signed by Her Majesty Queen Elizabeth II, Head of the Commonwealth, Commonwealth Day 2013.

Danel Ł., The Asian Part of the Commonwealth - the Problematic Case of the Maldives, [in:] Peculiarities of China's Politics and Culture, eds. J. Marszałek-Kawa, K. RezmerPłotka, Toruń 2019.

Daniyal S., History revisited: Why did Nehru give up his bitter opposition to the Commonwealth and join in 1947?, Scroll.in, April 24, 2018, https://scroll.in/article/876483/ history-revisited-why-did-nehru-give-up-his-bitter-opposition-to-the-commonwealth-and-join-in-1947.

Duncan Hall H., Commonwealth. A History of the British Commonwealth of Nations, New York 1971.

Fergusson N., Empire. How Britain Made the Modern World, London 2003.

Freedom in the World 2020. A Leaderless Struggle for Democracy, Freedom House, https://freedomhouse.org/ sites/default/files/2020-02/FIW_2020_REPORT_BOOKLET_Final.pdf.

https://thecommonwealth.org/declaration-commonwealthprinciples.

https://thecommonwealth.org/member-countries.

https://thecommonwealth.org/sites/default/files/page/documents/CharteroftheCommonwealth.pdf.

India and the Commonwealth, Ministry of External Affairs (UNP Division), August 2011, https://mea.gov.in/Portal/ ForeignRelation/commonwealth-august-2011.pdf.

Kreling B., India and the Commonwealth: A Symbiotic Relationship?, "The Round Table" 2009, vol. 98, no. 400. Lloyd T., Empire. The history of the British Empire, LondonNew York 2001. 
London Declaration, Issued at the Commonwealth Prime Ministers Meeting, London, United Kingdom, 22-27 April 1949, https://thecommonwealth.org/sites/default/ files/inline/London-Declaration.pdf.

Moore R.J., Mountbatten, India, and the Commonwealth, "Journal of Commonwealth \& Comparative Politics" 1981, vol. 19, no. 1 .

Murthy C.S.R., India and the Commonwealth: Redirecting the Relationship, Carnegie India, April 11, 2018, https:// carnegieindia.org/2018/04/11/india-and-commonwealth-redirecting-relationship-pub-76054.

Roy-Chaudhury R., India's new political interest in the Commonwealth, The International Institute for Strategic Studies, April 17, 2018, https://www.iiss.org/blogs/analysis/2018/04/india-interest-commonwealth.

Srinivasan K., Nobody's Commonwealth? The Commonwealth in Britain's Post-Imperial Adjustment, "Commonwealth \& Comparative Politics" 2006, vol. 44, no. 2.

\begin{abstract}
The article is devoted to India's membership in the Commonwealth of Nations. Although this membership dates back to Indian independence, so until 1947, for a very long time, this organization did not play any significant political and economic role in the implementation of India's foreign policy goals. However, the last few years have seen a growing interest in the Commonwealth on the part of the Indian political leadership, particularly its current prime minister Narendra Modi.

The article answers the question of what lies behind the mentioned change in India's approach to the Commonwealth and how India tries to use this international organization to build its global position. The author tries to prove the thesis that for today's India, the importance of the Commonwealth may turn out to be crucial
\end{abstract}


in the context of the competition with other global players. He also points out that the United Kingdom of Great Britain and Northern Ireland may soon become one of India's main allies since the postBrexit reality forces the former empire to strengthen its position outside of Europe. A strong and stable Commonwealth can be an essential means of achieving this.

Keywords: India, Commonwealth, United Kingdom, Asia, leadership

\begin{abstract}
Abstrakt
Pracę poświęcono członkostwu Indii we Wspólnocie Narodów. Chociaż jego początek sięga lat odzyskania niepodległości przez Indie w 1947 r., organizacja ta nie odegrała w tym czasie znaczącej roli w kształtowaniu i implementacji celów polityki zagranicznej Indii. Jednakże w ostatnich latach można było zaobserwować rosnące zainteresowanie Wspólnotą Narodów ze strony przywódców Indii, szczególnie obecnego premiera - Narendry Modi.

Celem pracy jest odpowiedzenie na pytania, co jest przyczyną zmiany stanowiska Indii wobec Wspólnoty Narodów oraz jak Indie zamierzają wykorzystać tę organizację międzynarodową do budowania swojej pozycji na arenie międzynarodowej. Autor stara się udowodnić tezę, że Wspólnota Narodów może okazać się kluczowa dla Indii w kontekście rywalizacji z innymi graczami w skali globalnej. Wskazuje też, że w pobrexitowych realiach Zjednoczone Królestwo Wielkiej Brytanii oraz Irlandia Północna wkrótce mogą stać się największymi sojusznikami Indii, gdyż dawne imperium będzie zmuszone do wzmocnienia swojej pozycji poza terytorium Europy. Silna i stabilna Wspólnota Narodów może okazać się kluczowym narzędziem, niezbędnym do osiągnięcia tego celu.
\end{abstract}

Słowa kluczowe: Indie, Wspólnota Narodów, Zjednoczone Królestwo, Asia, przywództwo 


\section{The Socio-political Impact of the May 4 Movement on Chinese Nationalism, Civil Society and Rejection of the Confucian Tradition}

\section{Introduction}

After World War I, decisions made after the Paris Peace Conference had severe political consequences on a global scale. In Europe, they disintegrated and created new state entities. The balance between powers changed, with the United States of America taking the first position. Gradually, a bipolar system of international relations developed, reaching its final form after World War II. Under the influence of the idealistic vision of the world of American President Woodrow Wilson, the League of Nations was created, a universal international organization whose main task was to ensure the "territorial integrity and political independence" ${ }^{1}$ of its members and to supervise the implementation of the provisions of the Versailles Treaty, regulating the global principles of international political and economic relations, as expressed by W. Wilson in

1 W. Wilson, Kształtowanie losów świata. Pamiętniki i dokumenty, vol. I, Warsaw 1924, p. 211. 
the so-called "14 points", announced in Congress on January $8,1918^{2}$. However, China was not among the beneficiaries of the "new world order" even though the Middle Kingdom took part in the war on the side of the Entente countries. The decisions made during the Paris conference were against China's raison d'état, keeping the country an economic base for the powers that were strengthening its position, especially Japan, which had been granted the rights to German concessions in China. The public protest found an outlet in the revolutionary May 4 Movement, which spread from Beijing to all major cities of the Republic of China, revealing the new face of Chinese society.

The $100^{\text {th }}$ anniversary of these events prompts us to consider the proper causes of the outbreak of the May 4 Movement and its impact on shaping internal social relations and changes taking place in the Chinese socio-political space. Therefore, the considerations presented in this lecture are focused mainly on the attempt to identify the phenomena taking place in Chinese society as a result of the development of relations with the outside world, bringing new political and economic trends and new ideological values.

With the end of Dynastic China, new tendencies emerged to create non-governmental institutions in the political and economic areas and many others beyond the control of the state. The impulse came with deepening China's relations

2 S. Jones, The Fourteen Points of Woodrow Wilson's Plan for Peace, https://www.thoughtco.com/the-fourteen-points-3310117 [access: 7.07.2019]; R. Wilde, Woodrow Wilson's Fourteen Points, https://www. thoughtco.com/woodrow-wilsons-fourteen-points-1222054 [access: 5.08.2019]. 
with the Western world and developing Chinese activity in the public sphere of social life, supported by Chinese entrepreneurship, education, and the press. The foundations of civil society were created, inseparably connected with the expansion of knowledge and division of labor, which enabled specialists to proclaim autonomy in the sphere of their special competences, in contradiction to the traditional social order, in which power constitutes comprehensive supervision over people's lives. These changes took place slowly and were not completed until the most recent times. The hallmarks of democracy revealed by the parliamentary system were exhausted in the confrontation of statutory law with state institutions that failed to break free from the influence of the feudal system of social relations. The law was giving way to the authority of the official. The individual was still subordinated to the interests of the group. Despite the implementation of the modernization and New Science processes, a complete rejection of Confucianism proved beyond the capacity of Chinese reformers unable to discard inherited Chinese values. An expression of this attitude towards reality was the thesis of the then ideologist Zhang Zhidong: "Chinese science is the foundation, and Western knowledge serves practical purposes", which was widely accepted as an expression of the primacy of Chinese science over the Western set of "practical tools"

The deepening of "implanting" European patterns was significantly limited by defragmentation of the state under the influence of warlords plundering China, operating with considerable support from abroad. Moreover, their activity was accompanied by the support of foreign armies operat-

3 J.K. Fairbank, Historia Chin. Nowe spojrzenie, Warsaw-Gdańsk 2003, pp. 237-240. 
ing on water and land connected with the threat posed by the supported adventurers. Under these conditions, Chinese nationalism took shape, directed against external forces and internal oppressors, seeking social concepts between authoritarian collectivism and liberal individualism ${ }^{4}$.

As the economy grew, the number of Chinese workers grew. In 1913, the Chinese industry employed about 650,000, in 19181.75 million, and 2.35 million in 1919 . Over 10 million wage laborers found employment in trade, and many million agricultural workers also worked in agriculture 5 . In 1920,870 thousand workers were employed in the mining industry, 1100 thousand in general industry, 200 thousand in transport, and 150 thousand in ports. Their total number constituted only $1 \%$ of the entire society ${ }^{6}$. The huge reserve of human resources contributed to this social group's very bad financial situation, resulting in the lack of proper legislation and social security and the lack of institutions responsible for protecting their interests. The workers, led mainly by various secret societies, fraternities, compatriots, and guilds, were under the influence of entrepreneurial intermediaries, merchants, and even gang leaders. Only the fact that the workers were largely concentrated in the industrialized regions helped to release the phenomena of opposition, at first vigorous and gradually more and more organized.

Even though the conservative part of Chinese society severely criticized the West, the Western model of social

4 J. Haapanen, Adaptation to World Trends. A Rereading of the May Fourth Movement Radicalization, Juvaskyla 2013, p. 236.

5 S.L. Tychwinski (ed.), Historia nowożytna Chin, Warsaw 1979, p. 654.

6 W. Rodziński, Chiny w ogniu. Rewolucja w latach 1925-1927, Wrocław-Warsaw-Kraków-Gdańsk-Łódź 1983, p. 9. 
relations influenced the views of the Chinese intelligentsia. China introduced changes to the education system by introducing a three-tier education system. Contacts with foreign countries made it possible to study at Western universities, especially in Japan. At the beginning of the 20th century, the number of Chinese students in Japan increased rapidly: in 1904, there were 130 , in $1905,8,000^{7}$, and in 1907 , there were already about $15,000^{8}$. At that time, about 400 Chinese studied in Europe, and about 800 in the USA 9 . The development of schooling in China has contributed to reducing illiteracy; in 1910, about 57 thousand people operated in China, schools employing approx. 89 thousand teachers. The number of students at that time was estimated at around 1.6 million ${ }^{10}$. Tens of thousands of young people have studied Western philosophy, from liberalism to Marx. The book market was filled with translations of Western literature. By resigning from accepting the "boxing" contribution, the United States donated its share (\$12 million, i.e., 50\% of the compensation agreed in the boxing protocol) to support Chinese education, financing both universities created by the mission of the American Episcopal Church in China, as well as funding students in the USA. Often the language of instruction was English ${ }^{11}$.

Following the example of the West, journalism and press publishing was spreading in China, and the number of readers, estimated in the 1930s at 20-30 million, also grew. In

7 S.L. Tychwinski (ed.), op.cit., p. 419.

8 W. Rodziński, Historia Chin, Wrocław-Warsaw-Kraków 1992, p. 538 .

9 Ibidem.

10 Ibidem.

11 J.K. Fairbank, op.cit., pp. 244-245. 
1912, about 500 newspapers were published in China, and in 1928 about 600. Only in Shanghai and Beijing, 40-50 newspapers with a circulation of up to 150,000 were published copies ${ }^{12}$. Magazines, textbooks, and mass fiction were published on a large scale. Political journalism was mainly polemical, focused on criticism and defense, less often on communicating facts. Gradually, the press became an important tool of political agitation and struggle ${ }^{13}$.

The geographic and spiritual center of the New Culture was the Peking University, founded in 1898, at first known as the Imperial University - a center that educated and educated employees of the imperial government administration. After the revolution of 1911, the reformer Yan Fu, the first translator of Mill and Spencer into Chinese, became the university rector. Even though he held the position for only a few months, he significantly raised the level of education by employing outstanding lecturers. Among those who joined the university staff were Chen Duxiu and Li Dazhao, later founders of the Communist Party of China, and $\mathrm{Hu}$ Shi - one of the greatest writers of modern China. In 1916, Cai Yuanpei became the rector. He was an excellent scientist, an advocate of modern education, educated at a university in Germany. He promoted "academic freedom", which resulted in publications criticizing Confucian morality and the Confucian system of values in favor of the freedom of the individual and individual development and the building of a new world view ${ }^{14}$.

The second great center of New Culture was Shanghai an open colonial city with approx. 1.2 million inhabitants,

12 R. Mitter, Gorzka rewolucja. Zmagania Chin z nowoczesnym światem, Warsaw 2008, pp. 84-85.

13 J.K. Fairbank, op.cit., pp. 242-243.

14 R. Mitter, op.cit., s. 59. 
aspiring to the rank of metropolis similar to Tokyo, Paris, or New York, where big business and the most important banking headquarters were concentrated, including Hongkong and Shanghai Bank. The city's architecture of that time referred to the style of European and American construction with a large share of several-story high-rise buildings. There was relatively great political freedom and tolerance for the Western way of life in the city. However, xenophobic and racist attitudes have not been eliminated. The Chinese were often exposed to racist treatment by the British, French, Americans, and Japanese. Some public places were inaccessible to them. The seemingly cosmopolitan city was a place of development for Chinese nationalism ${ }^{15}$.

Although Peking University was the most prestigious Chinese university, Shanghai provided education at all levels and for all levels. St. John's University, founded there in 1879, educated the children of the local elite and became the most outstanding Christian university in the 1920s. By contrast, Shanghai University, founded in 1922, had a reputation for being more radical, with communist luminaries among the lecturers such as Qu Qiubai (the future leader of the CCP) and Deng Zongxia. An important element of learning was the English language, in which most of the textbooks for learning new Western subjects were published ${ }^{16}$.

Along with the New Culture Movement in China, a new way of thinking about the individual's social role began to be adopted, which was fostered by the increase in the readership of popular literature, especially in the dissemination of colloquial language replacing the fossilized Confucian lan-

15 Ibidem, pp. 63-64.

16 Ibidem, p. 65. 
guage ${ }^{17}$. Confucian dogmas of modesty and collective good were rejected in favor of Western models of self-realization and the development of one's individuality, the beneficiaries of which were also Chinese women, who gained universal access to education and education, undertaking activities reserved exclusively for men in workers' professions and free professional groups of doctors, teachers, lawyers, writers, etc. Influenced by the activity of the consumer culture in large urban centers, a movement for women's rights was developing, which was reflected in the fact that Chinese women won (only nominally) 1927 constitutional voting and civil rights ${ }^{18}$. However, feminism met with strong resistance from conservatives, but during the period of the Movement for New Culture, it was most openly posed, finding the widest social support ${ }^{19}$.

The influence of Western culture on the New Culture Movement in China, apart from society's political and general area, also manifested itself in the dimension of art and literature. Chinese art took advantage of the influences of iconoclastic anti-Confucian sentiments, adopting Western patterns. Many artists went to Europe, mainly to France and Great Britain, others went to study in Japan. Some of them received government scholarship support through the established National Academy in Beijing, which allocated

17 Ch.W. Hayford, Literacy Movement in Modern China, https:// www.researchgate.net/publication/300450509_Literacy_Movements_ in_Modern_China [access: 6.08.2019].

18 M. Koetse, Gendered Nationalism and May Fourth: China's „New Woman", https://www.manyakoetse.com/gendered-nationalism-andmay-fourth-chinas-new-woman/ [access: 23.08.2019].

19 M. Mencel, Kobieta w Chinach: kulturowa przeszłość i teraźniejszość, [in:] Kobiety w życiu kulturowym Polski i świata, eds. A. Chodubski, A. Frączek, B. Słobodzian, Gdańsk 2012, pp. 208-227. 
some funds to study fine arts in Europe ${ }^{20}$. The number of art schools in China, bringing Western culture to Chinese art, grew rapidly. Concentrated around the schools of Shanghai, Nanjing, Hangzhou, Beijing, and Canton, new art adherents focused their efforts on creating art societies and organizing exhibitions, thus opening up new opportunities for the exchange of ideas. The magazines created as a result of the May 4 Movement became the best means of presenting new styles and theories to a broader audience, becoming a challenge for the authorities of Chinese traditional art, and the activity of Chinese artists was expressed in 1924 by the organization of the first exhibition of Chinese modern art in Europe, often combining techniques learned in European studies with traditional Chinese methods of artistic expression $^{21}$.

The presented image of a fragment of "modern" China cannot dominate the actual state of Chinese reality: widespread poverty, life on the verge of poverty and hunger, everyday struggle for the existence of the vast majority of the inhabitants of these two (and other) huge metropolises, pushed to the outskirts of cities, providing cheap power labor for both imperialist entrepreneurs and the native bourgeoisie, sources of exploitation for central and local leaders. The situation of the inhabitants of the Chinese countryside was equally dramatic, the population of which constituted over $80 \%$ of the total number of China's population of $430-$ -480 million in the 1920 s, remaining in deeply embedded feudal social relations. Despite the indisputable diligence of Chinese peasants, the level of Chinese agriculture was

20 A.I. Król, Chiny w latach 1898-1937 - między artystyczną tradycja a sztuką Zachodu, Warsaw-Toruń 2016, p. 71.

21 Ibidem, pp. 68-75. 
technically backward, especially when compared with the large-scale agricultural economies of Western countries. Most agricultural areas were dominated by the natural or semi-natural economy principles, expressed in autarkic self-sufficiency, with no significant links to the market economy, mainly limited to coastal provinces and suburban areas. Chinese agriculture at the time was characterized by the excessive use of unlimited human labor, intensive cultivation methods, complete primacy of plant production, and minimal importance of animal husbandry. The maintenance of irrigation systems was the responsibility of the local and central authorities, which were not interested in directing investment outlays for their modernization, which in many regions led to a reduction in the yields obtained due to drought or flood phenomena. The guardian of systemic immutability was the bureaucracy that was shaped by the centuries and its representatives, which on the one hand led to the enormous civilization progress of dynastic China, also guaranteed systemic and cultural stabilization in the empire, and on the other hand contributed to the socio-economic stagnation that led to backwardness and civilization delay in relation to the West and Japan, in which the transformations were created by the industrial revolution, capitalism, and then democratic state systems. From the nineteenth century on, a serious burden for China was rural overpopulation and the lack of proportion between the overall population growth and the increase in production, which resulted in the impoverishment of the inhabitants, especially in rural areas. The ratio of agricultural land to the number of inhabitants decreased ${ }^{22}$. From 1901 to 1928, the population

22 It is estimated that $50 \%$ of agricultural land belonged to the landowners, $33 \%$ to rich and middle-class peasants, and only $17 \%$ to the poor- 
increased by 50 million, accumulating mainly in the rural areas of the country, where the tendencies and trends of the New Culture Movement did not reach. The radical increase in the rural population was influenced by a traditional factor derived from Confucian culture, according to which the farming profession was highly respected, and the attachment to numerous offspring resulted from patriarchal social customs. The central and local administration also focused efforts in rural areas to support the traditional value system. The village was the main taxpayer, providing workforce and recruiting for the government army and local warlords ${ }^{23}$. The overwhelming majority of peasants did not have any financial resources, so they often took out loans granted on usury terms by large landowners or local administration representatives. The repayment of the loan and the obligatory levies was often an unbearable burden for the Chinese peasants. As a consequence, they lost their lands and fell into unimaginable poverty. The Cultural Revolution, which took over the urbanized areas of Chinese cities and coastal provinces, did not affect the Chinese countryside in any way, contributing to the creation of a specific social duality, dividing society into revolutionary, reformist, pro-modern (approx. 10-15\% of the population) and pro-democratic and traditional and maintenance. In retrospect, the chances of victory for the May 4 Movement were zero.

est peasants. The Chinese countryside was also characterized by a high level of stratification: $70 \%$ were poor peasants and agricultural workers, $20 \%$ were middle-class peasants, and $10 \%$ were landowners and rich peasants. Thus, $10 \%$ of the Chinese rural population earned an income of $88 \%$ of the acreage. W. Rodziński, Chiny w ogniu..., op.cit., pp. 4-5.

23 M.T. Mencel, Wiejski charakter chińskiego społeczeństwa, [in:] Chińska Republika Ludowa jako wspótczesny podmiot środowiska międzynarodowego, vol. III Rozważania o rzeczywistości, ed. M.T. Mencel, Toruń 2016, pp. 894-960. 
Under these conditions, many Chinese found the offer made by the representatives of the Soviet Union after the victory of the October Revolution attractive. In the proclamation of December 3, 1917, the Soviet government stated that it was renouncing all unequal agreements between the tsarist government and the eastern nations and annulling secret agreements with other powers that would restrict the sovereign rights of the eastern nations. News began to reach China about the principles of the political system of the Soviet state, Marxist-Leninist ideology, and their influence on the "liberation" of the people of Russia from the power of self-control and colonial oppression ${ }^{24}$. The Chinese press published reports on events in Russia, especially in the context of the proposal by the Council of Workers' and Soldiers' Delegates to "conclude a democratic peace", "abolish landownership and transfer it to the peasants". China widely echoed the news that the workers and peasants had won power in Russia, and the qualitative dimension was raised by the declaration of the Soviet authorities on February 10, 1918, on the cancellation of the debt owed to China by the loans granted and the cancellation of the Sino-Russian treaty of 1896 and the Protocol boxing of 1901. According to the Soviet declaration of July 25, 1919, Sino-Soviet relations should be based on non-interference in China's internal affairs. In 1920, the Far Eastern Railway, managed and supervised by the Russians, was taken over by the Manchurian warlord Zhang Zuolin ${ }^{25}$. Since then, the Soviet communists have shown considerable commitment to engage in relations with China, sending official delegations to Beijing whose

24 G. Jefimow, Zarys nowożytnej $i$ wspótczesnej historii Chin, Warsaw 1953, pp. 206-207.

25 W. Rodziński, Chiny w ogniu..., op.cit., pp. 37-38. 
task was mainly to build positive relations and trust. Due to the lack of understanding on the part of Western countries, Sun Yat-sen took advantage of the Soviet proposal, who in a letter to Georgi Chicherin (November 24, 1872-July 7, 1936) was to write: "I am very interested in your cause, especially in the organization of your Councils, your army and your education [...]. Like Moscow, I would like to instill the principles of the Republic of China deeply in the minds of the young generation - the working people of tomorrow"26. After several years of contact with representatives of the Comintern, both sides agreed on the principles of cooperation: on January 7, 1923, Sun Yat-sen accepted the principles of Moscow's policy towards China, and on May 31, 1924, a Sino-Soviet cooperation treaty was concluded ${ }^{27}$. Guomindang's relations with the Comintern, whose advisers participated in the reorganization of the National Party of China according to Soviet patterns, intensified.

The literature on the subject emphasizes the importance of the May 4 Movement for shaping the foundations of the Communist Party of China ${ }^{28}$. However, it is difficult to see direct connections between the general social movement of opposition to anti-social feudal internal relations and the oppression of warlords, and the humiliating domination of imperialism by foreign powers, with the formation of communist attitudes. Nevertheless, the main creators of the CCP were also in the May 4 Movement's upheaval, and

26 W.I. Głunin, Przypływ ruchu narodowowyzwoleńczego w Chinach (1917-1924), [in:] Najnowsza historia Chin (1917-1976), eds. G.W. Astafiew, W.N. Nikiforow, M.I. Sładkowskij, Warsaw 1976, p. 108; ibidem, pp. 39-42.

27 Ibidem, pp. 39-42.

28 K. Gawlikowski, Nowa batalia o Konfucjusza, Warsaw 1976, pp. 50-51. 
these links are hard to deny, although it is appropriate to emphasize the links between the early theories of Chinese communists and European and Russian anarchism, having little in common with orthodox Marxism. The ancestors of Chinese communism used rather the theories of Proudhon, Bakunin, and Kropotkin, seeing in them patterns of contestation of all authorities, especially those originating from the power environment and the coercive apparatus, reaching even the social foundations of the family, in favor of an egalitarian utopian community ${ }^{29}$.

There is no doubt that on the wave of the Movement for New Culture, Chinese interest in the theory and practice of socialist socialism and communism has increased, especially due to disappointment in relations with the West ${ }^{30}$. Li Dazhao (1888-1927), Zhen Duxiu (1879-1942) - one of the main activists of the May 4 Movement.

Li Dazhao was a professor at Peking University, then the main center of the intellectual movement in China. As early as 1918, he published an article glorifying the ideas of the October Revolution in Russia in the progressive journal "New Youth" (Xin Qingnian) ${ }^{31}$. Taking up a fanatical ideological struggle with Confucianism, he preached the slogan "Destroy the stall of Confucius and his heirs", encouraging the rejection of everything old and reactionary, especially the principles of filial obedience, recognized as the foundation of feudal China ${ }^{32}$. In 1918, Li Dazhao founded the Marxist Scientific Society, which aimed to deepen Marxist

29 J.K. Fairbank, op.cit., pp. 255-256.

30 J. Bayer, W.J. Dziak, Historia polityczna Chin 1839-2014. Konspekt analityczny, Warsaw 2016, p. 127.

31 W. Rodziński, Chiny w ogniu..., p. 51.

32 K. Gawlikowski, op.cit., p. 51. 
philosophy ${ }^{33}$, and in 1920 established a communist circle of nine in Beijing. During the events of $1919^{34}$, Li published his translation of the first part of the Communist Manifesto ${ }^{35}$. Li Dazhao was arrested on Zhang Zuolin's order and executed on April 28, 1927, in Beijing and 19 other communists ${ }^{36}$.

In 1919, support for the communist ideology was announced in the pages of "New Youth" by Zhen Duxiu", dean of the Faculty of Humanities of Peking University, founder of the first communist group in September 1920 in Shanghai, numbering seven people ${ }^{38}$. Zhen constructed views similar to Li Dazhao, but they were more radical. In his famous appeal to the young, he called on the representative of the younger generation to be independent, allowing them to create their own personality to a greater extent. At that time, critical words were spoken of the elderly, who, under Chinese conditions, had a powerful influence on shaping attitudes. According to Chen, this formula was exhausted, so it was necessary to create a field for young minds to act. Chen encouraged people to learn from other cultures by being open to new solutions. He rejected old myths and images, attaching great importance to the reform of the writing. Thanks to

33 M. Kukowski, Proces przyjęcia i odrzucenia japońskiego wzoru przez Chiny. Od końca XIX wieku do 1937 roku, https://mysl.lazarski.pl/ fileadmin/user_upload/dokumenty/czasopisma/mysl-ekonomiczna-polityczna/2014/MEiP_1_7_2014_Kukowski.pdf [access: 5.08.2019].

34 W.I. Głunin, op.cit., p. 89.

35 Ł. Gacek, Rola konfucjanizmu w kształtowaniu ideologii państwowej w Chinach w XX wieku, „Krakowskie Studia Międzynarodowe” 2015, no. 3, p. 29.

36 Li Dazhao, https://pl.wikipedia.org/wiki/Li_Dazhao [access: 5.08. 2019].

37 W. Rodziński, Chiny w ogniu..., p. 27.

38 W.I. Głunin, op.cit., p. 89. 
the experience gained during his studies in Japan and France, Chen became interested in socialist doctrine. He later called for systemic changes in line with socialist theories, strongly rejecting the Confucian legacy. It is worth emphasizing that Chen Duxiu was educated based on the canon of classical Confucian books, which did not prevent him from expressing diametrically opposed views later on $^{39}$. During the May 4 Movement, its motto was: "Overthrow the old idols! Demolish everything!" ${ }^{0}$ which strongly expressed his anarchist views. He argued that Confucianism was a product of the feudal era and did not meet the needs of modern times, he saw in it one of the main inhibitors to China's development, the cause of the country's backwardness. He accused Confucianism of practicing empty rituals, promoting consent and obedience that prevented fighting and competition, and imposing a passive attitude on the whole nation. In his opinion, modern times strive for the development of the individual, strengthening his rights, without which democracy, economic and political development, or building a strong state are not possible, and Confucianism takes the family and clan as its basis, it is an ideology that destroys all individualism. He pointed out that the transformation of Confucianism into the state religion, the choice of this way of building modern China, is contrary to the rationalist spirit of Confucianism ${ }^{41}$. Both Zhen Duxiu and Li Dazhao criticized Confucian attitudes towards women, demanding a radical change in the position of women in society ${ }^{42}$.

39 Ł. Gacek, op.cit., p. 29.

40 K. Gawlikowski, op.cit., p. 51.

41 Ibidem.

42 R. Sławiński, „Nowy” konfucjanizm w krajach Azji Wschodniej, „Krakowskie Studia Międzynarodowe” 2010, no. 1, pp. 142-143. 
A radical attitude towards Confucianism was demonstrated by Lu Xun (1881-1936), often indicated as the leading figure of the May 4 Movement and the greatest writer of contemporary China. In 1918, he published an essay in "Nowa Młodzież" entitled My views on cleanliness, in which he condemned the traditional approach to the place and role of women in society ${ }^{4}$. In his Journal of the Mad, he pointed to Confucianism as a doctrine of cannibalism. The anonymous protagonist of the story concludes the situation in China: "Only today I realized that I, too, had lived here for many years, in this place where people have constantly been eating for four millennia"44. "After four thousand years of practicing cannibalism, I felt unexpectedly ashamed of it. If there are children who have not yet practiced cannibalism, save them" 45 . Even though the practices of cannibalism in Chinese reality were a marginal phenomenon, recalling them aroused vivid emotions, strengthening anti-Confucian moods. It was claimed that Confucian morality kills humanity in man, is the basis of inhuman social relations, oppression accepted even without rebellion, "devouring people" by despots and rich people. Lu Xun argued that it was the inhuman Confucian tradition that overwhelmed people that threatened with annihilation. He argued for accepting only what is new and progressive from the West, from Russia, from the achievements of the new China, and for rejecting everything that is old and conservative ${ }^{46}$.

Despite its nationalist significance, the New Culture Movement assimilated the Western system of values, striv-

43 R. Mitter, op.cit., p. 113.

44 Ibidem, p. 114.

45 K. Gawlikowski, op.cit., p. 52.

46 Ibidem, p. 53. 
ing to provide China with a dignified place in the international environment. People's way of life came to be seen with a cultural and political context. For the first time in China's long history, the status of women, the nature of modern marriage, and the model of family relations have taken center stage in public debate. The anti-imperialist and anti-feudal attitude of society was expressed by the concept of Chen Duxiu, radical in his views, who pointed out that China needed "Mr. Science" and "Mr. Democracy". The role of the former was to replace the Confucian classics with a positive, rational way of reasoning, and the latter to promote a new moral system and political freedom. Both "gentlemen" had a chance to survive the rivalry with the West inscribed in social Darwinism - especially with Japan and the warlords' greed ${ }^{47}$.

The events of the Paris Peace Conference had a direct impact on the outbreak of the May 4 Revolution. They were preceded by the opposition of Chinese society to the decision of the Duan Qirui government to involve the Chinese armed forces in the intervention of 14 states against Soviet Russia in the Far East. The agreements of May 16 and 19, 1918 on subordinating the directed Chinese troops to the Japanese command led to the organization of a protest strike in Tokyo by Chinese students. During the rally, they decided to leave Japan en masse and return to China: by the end of 1918, about 3,000 people left Japan. After returning home, Chinese students started mass anti-imperialist and anti-militarist agitation in Shanghai, Beijing, and other

47 J. Fenby, Chiny. Upadek i narodziny wielkiej potęgi, Kraków 2009, p. 227. 
cities. On May 21, 1918, students from many Beijing universities launched a protest strike against Japanese-Chinese military agreements and held demonstrations outside the government headquarters. The demonstrators protested against the aggressive military arrangements, against China's participation in the anti-Soviet intervention, against the policy of national treason by the Duan government, and demanded friendly relations with Soviet Russia. The students' speeches and demands were supported by various strata of Chinese society and even by Sun Yat-sen himself. He supported the recognition of Soviet Russia, and the October Revolution had a strong influence on Sun's views. In a congratulatory telegram sent to Lenin, he indicated that "The Chinese Revolutionary Party expresses its deep admiration for the difficult struggle that your country's revolutionary party is waging, and believes that the revolutionary parties of China and Russia will come together for a common struggle" 48 .

Parallel to the interest in the events taking place in Soviet Russia, many enlightened citizens had great hopes for strengthening China's position in the face of Japanese imperialism with the international order introduced during the peace conference in Paris after the end of World War I and especially with the principles set out by President Woodrow Wilson in his "14 points" and declarations made before the conference on the need to restore China's sovereignty over the annexed territories. However, Wilson's submission to Japanese pressure backed by the British and French at the conference disappointed Chinese patriots. The requests made by the Chinese delegation were rejected in their en-

48 Ibidem, p. 666. 
tirety. During the conference, it was stated that the issue of the Japanese "21 demands" was not within the scope of the conference's work, and it was decided to consider Chinese demands according to the procedure provided for by the established institution - the League of Nations. In the Shandong case, the peace treaty stipulated that the rights and privileges obtained by Germany under the Sino-German Agreement of March 6, 1898, and all other Shantung Agreements, and the Jiaozhou territory, railways, mines, sea cable, etc. Japan takes over everything. Japan took over Germany's rights to the Jiaozhou-Jinan railway and all its sidings and all property of that railroad and all mines and facilities and related rights and privileges. The sea cable from Tsingtao to the island of Taiwan and all associated property also passed into the hands of Japan without compensation ${ }^{49}$.

The first news of the decisions made at the Paris Peace Conference reached young Chinese students studying at French universities who initiated a protest in front of a hotel where a Chinese government delegation was accommodated, preventing the Chinese from signing a peace treaty ${ }^{50}$. News from Paris quickly reached Beijing, escalating the indignation and opposition of students who, on May 4, 1919, organized a mass rally in Beijing's Tiananmen Square, of which approx. people, equipped with banners with slogans like: Down with the traitors, headed for the embassy district. Their destination was the home of Cao Rulin, the minister of communications considered to be one of the "traitors to the nation", who had traded Japan with China's economic and political independence. The house was demolished, the

49 A. Malicka (ed.), Najnowsza historia Chin, Warsaw 1954, p. 38.

50 J. Fenby, op.cit., p. 224. 
minister fled to the foreigners' hotel, the minister's Japanese guest fell victim to the crowd and thrown eggs, and all the crowd's anger fell on the former Chinese envoy in Japan, Zhang Zangxiang, who was visiting Cao Rulin's house ${ }^{51}$. Zhang was severely beaten using metal pieces dismantled from an iron bed. Then the house was set on fire, and the police entered the action arresting several dozen perpetrators. Further arrests in Beijing took place on June 2 and $3^{52}$. Protests and rebellions broke out in other cities as well. Students from Tianjin, Shanghai, Nanjing, Wuhan, Fuzhou, Guangdong, Guangxi, Shanxi, Shaanxi, Zhejiang, Jiangxi provinces joined.

At the beginning of June 1919, workers joined the student movement by taking strike actions. On June 5, merchants in Shanghai started a strike, followed by merchants in other commercial ports. The strike was joined by the workers of Shanghai mechanical plants, copper and tin processing plants, and following their example, the strike was undertaken by printers, textile workers, railroad workers, and tram drivers. The May 4 movement mobilized various strata in a united protest, which eventually led to the concessions of the government, which on June 9, 1919, removed Cao Rulin (1876-1966), Lu Zongyu (1876-1941), and Zhang Zongxiang (1876-1962) and issued a ban on MPs in Paris from signing a peace treaty that included provisions unfavorable to China ${ }^{53}$.

51 B. Góralczyk, Pekińska wiosna 1989. Początki ruchu demokratycznego w Chinach, Warsaw 1999, pp. 15-16.

52 R. Mitter, op.cit., pp. 23-25.

53 Yang Chunmei, The May Fourth Movement in Chinese History. To understand the May Fourth Movement, we must first understand its ideological roots, https://www.sixthtone.com/news/1003904/the-mayfourth-movement-in-chinese-history [access: 6.08.2019]. 
The literature on the subject indicates broad active support for the May 4 Movement in China, as evidenced by the estimated number of students arrested at around 1,100. The support of the workers also seems considerable, especially when compared to the small Chinese proletariat. In Shanghai alone, approx. 60,000 people have started a strike ${ }^{54}$, and throughout China, about 100 thousand ${ }^{55}$. Manifestations and riots lasted from May 4 to June 28, 1919, covering all major cities in China. The anti-Japanese speeches were attended by representatives of all layers of the urban population: the intelligentsia, owners of trade and production and service enterprises, craftsmen and workers, which was the first such case in China's political history, expressing the general political awareness that shaped civil society. The massive support of the Chinese peasantry was not entirely successful, which made the movement unsuccessful, and most of all, the movement was led by an organization capable of systematizing a spontaneous social movement. Even Sun Yat-sen had no hopes for the May 4 Movement: Sun's pro-Japanese views and his compromise policy towards foreign powers ran counter to the anti-Japanese, anti-imperialist, and anti-colonial values that underpin the movement. He has never supported large mass movements, supporting local uprisings organized by a carefully selected elite. He regarded the demonstrating students as immature, naive people with limited knowledge of the revolution. In his political work, Sun Yat-sen focused on theoretical work (Three Principles of the People) by returning to the great

54 J. Wasserstrom, Liu Xinyong, Student protest and student life: Shanghai, 1919-49, https://www.jstor.org/stable/4285735?seq=1\#page_ scan_tab_contents [access: 15.07.2019].

55 W.I. Głunin, op.cit., p. 86. 
political scene and establishing the Chinese National Party (Zhongguo Guomindang) on October 10, 1919, following the tradition of the party established in 1912. Guomindang Statute, adopted on November 9, 1920, revealed the influence of the Leninist party, giving the most important prerogatives to the president-president, and the ideology was based on the Three Principles of the People. Departing from the Western model of the tripartite division of power, Sun saw the political system most appropriate for China, dividing powers into five state bodies, i.e., executive, legislative, judiciary, and examination - ensuring the inflow of properly educated, modern bureaucracy, and control (censorship) acting as the Chamber of Control ${ }^{56}$.

Ilustration 1. 1976 poster of the May 4 Movement by Liang Yulong

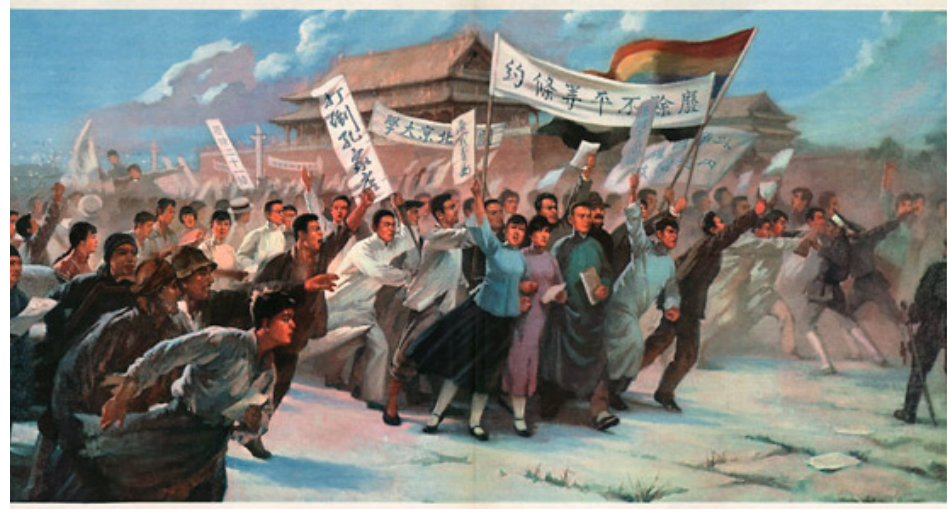

Source: https://chineseposters.net/posters/e15-575.php [access: 15.09. 2019].

56 B. Góralczyk, Sun Yat-sen. Misjonarz rewolucji, Warsaw 2013, pp. 105-106. 
Already two years after the outbreak of the student revolution, the patriotic movement for rebuilding the state and restoring society, fights with warlord feudalism, and imperial domination began to slow down gradually. Widespread criticism of Confucianism was also waning. As Guomindang strengthened in the national movement, supporters of Confucian ideology strengthened their position. After Chiang Kai-shek took power, the movement for shaping social relations in China was developed, referring to the main canons of Confucian virtues, political and social life models, making efforts to include elements of Western capitalism in Neo-Confucianism. The revival of the Chinese nation was equated with the Confucian revival: "[...] in the course of the renewal of Confucianism, modernity, and tradition, new and old, Chinese and Westerners will become a holistic unity and thus will be the future of China and the Chinese nation" ${ }^{57}$. The literature on the subject indicates that a significant part of Chinese society supported the thenconservatism and traditionalism of the National Party ${ }^{58}$, so the reactionary attitudes seem to be justified in Chinese reality.

Although the fires started by the May 4 Movement died out, the Movement for New Culture left a legacy to the next generations - the foundations of civil society, manifested in

57 Xinzhong Yao, Konfucjanizm. Wprowadzenie, Kraków 2009, p. 268.

58 K. Gawlikowski, op.cit., p. 54. 


\section{the events that took place in April 1976 $6^{59}$, May-June 198960,}

59 On April 5, 1976, during the Chinese Feast of the Dead and laying flowers at the Monument to the People's Heroes in Tiananmen Square, commemorating Zhou Enlai, who died that year (died on January 8, 1976), a celebration organized by students turned into a demonstration against the radicals. About 200 thousand people participated in it. people. The police dispersed the protesters and the propaganda classified the events as a "counter-revolutionary political incident". Two years later, after the death of Mao Zedong and the takeover of power by Deng Xiaoping, this assessment was reviewed, describing the events as "revolutionary action". Deng Xiaoping was charged for provoking the incident and he was once again stripped of all his posts. On April 7 this year, the duties of prime minister were entrusted to Hua Guofeng, who also took the position of vice-chairman of the CCP on the recommendation of Mao Zedong, and after his death on September 9, 1976 - chairman of the CCP. J. Bayer, W.J. Dziak, Historia polityczna Chin 1839-2014. Kronika najważniejszych wydarzeń..., op.cit., p. 304.

60 On April 23, 1989, before the official mourning ceremony after $\mathrm{Hu}$ Yaobang's death (died April 15, 1989) in Tiananmen Square, a group of students set up camp, raising slogans demanding that the party restore the good name of $\mathrm{Hu}$, who had been removed two years earlier. Fulfilling the demands would mean an admission of error by the CCP leadership, led by Deng Xiaoping. At the same time, dazibao (political posters) appeared at the Beijing university calling for the democratization of the country. On May 4, on the $70^{\text {th }}$ anniversary of the May 4 Movement of 1919 , a march was held in which approximately 50,000 people participated. students and approx. 250 thousand. residents of Beijing who put forward slogans of the democratization of the Chinese system: "Against the dictatorial rule", "Down with the corrupt government". The protesters' demands met with the understanding of Zhao Ziyang (1919-2005), the then secretary general of the CCP. Li Peng (1928-2019), acting prime minister of the PRC government, demanded a ruthless crackdown on the demonstrators. At that time, demonstrators demanded the resignation of Li Peng, escalating the slogans "Fight bureaucracy", "Fight corruption". The awakening movement was compared with the French Revolution. In connection with Mikhail Gorbachev's visit, the Chinese authorities did not undertake significant repression of the protesters, but 9.V. Deng Xiaoping and the "group of senior veterans" made the decision to dismiss Zhao Zyiang. 17.V. During an ad hoc meeting of the CCP authorities in Deng Xiaoping's residence, a decision was made to use force to end the demonstration, which had already reached about 1 million protesters. 18.V. On behalf of the highest authorities, Zhao Ziyang personally apologized to the demonstrators for mistakes made by the government. 20.V. a state of emergency was introduced in Beijing, with a group of generals 
and recently: in 2014 and 2019 democratic anti-government protests in Hong Kong, in which almost the entire society (around 2 million inhabitants took to the streets) opposed the decisions of the authorities intending to implement the law of the Chinese government on extradition to mainland China. Local authorities accuse demonstrators of striving for the "fall of Hong Kong", justifying the use of armed police units to brutally disperse Protestants. The Chinese propaganda apparatus supports the government's actions by escalating news about alleged aid provided to demonstrators by "Western agents" 61 .

Mao Zedong referred to the achievements of the May 4 Movement by initiating the Cultural Revolution in China in 1966, justified as follows: "after the end of the socialist

questioning the decision to send a military force to Beijing. 30.V. A copy of the New York Statue of Liberty - the Goddess of Democracy - appeared on Tiananmen to symbolize the demands of the protesters. 3.VI. Troops of the $27^{\text {th }}$ Army of the PAA entered Beijing, but the attempt to pacify the demonstrators was unsuccessful. The next day, more troops and security forces were introduced, which, on the direct orders of Deng Xiaoping, brutally pacified the revolt, and for the next months arrests of people recognized as provocateurs were carried out. J. Bayer, W.J. Dziak, Political History of China 1839-2014. Chronicle of the most important events..., pp. 304, 370-377. For many years, the public was informed about the number of victims on the side of demonstrators, estimated at a maximum of 2.7 thousand. In 2017, a report by the then British ambassador of Great Britain to China, Alan Donald, was released, in which he informs about over 10,000 victims, referring to the "trusted source", which was to be one of the members of the State Council. In the report, the ambassador also informs about the extraordinary brutality of Chinese soldiers against the protesters, many of whom were murdered on the spot. More in: Odtajniony RAPORT ws. masakry na placu Tiananmen: 10 tysięcy ofiar. DRASTYCZNE OPISY, https://wiadomosci.dziennik. $\mathrm{pl} /$ swiat/artykuly/565333, chiny-10-tys-ofiar-na-placu-tiananmen-wedlug-odtajnionego-dokumentu.html [access: 4.06.2019].

61 Wilfred Chan, Demokracja $i \dot{z} y c i e$ ludzi w Hongkongu? Bogowie globalizacji maja to $w$ nosie, https://krytykapolityczna.pl/hong-kong-protesty-2019/ [access: 17.09.2019]. 
Photo 1. Photo published worldwide - Student protesting in Tiananmen Square, Beijing

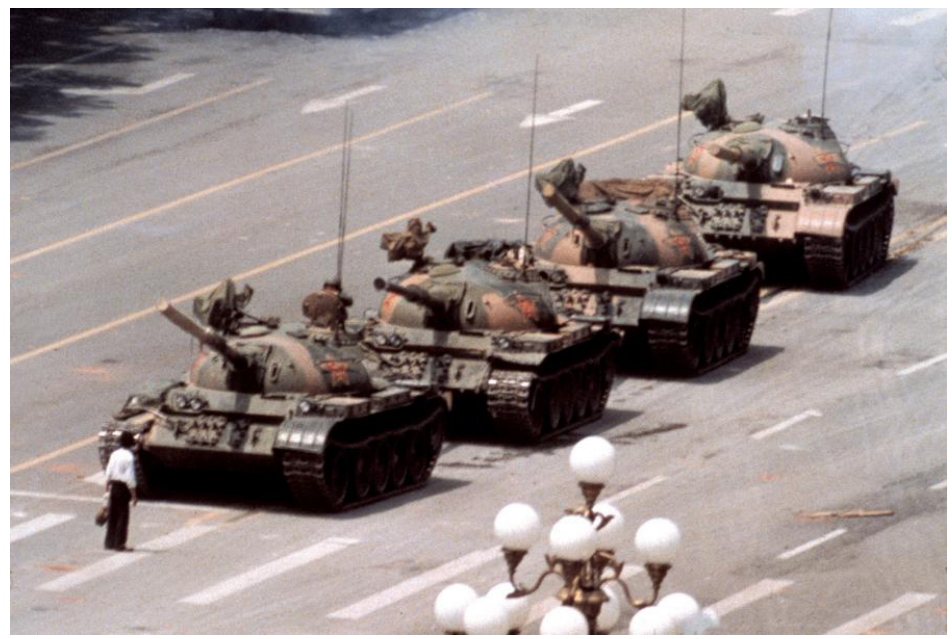

Source: https://wiadomosci.dziennik.pl/swiat/zdjecia/galeria/565333,1, chiny-10-tys-ofiar-na-placu-tiananmen-wedlug-odtajnionego-dokumentu.html [access: 4.06.2019].

transformation of the ownership of the means of production, a new revolution should come that will remove the remnants of bourgeois culture once and for all - from private thoughts to private markets" ${ }^{2}$. Following the revolutionary transition from capitalism to socialism, the transition from socialism to communism was also associated with a revolution whose face and most important mentor was to be only Mao and his Marxist-Leninist-Maoist ideology. The current leader of the PRC also points to the important role of the May 4 Movement in shaping Chinese communism: "The May 4 Movement contributed to the May 4 spirit of

62 The history of China during the Cultural Revolution is presented in the monograph in: F. Dikotter, Rewolucja kulturalna. Historia narodu 1962-1976, Wołowiec 2018. 
patriotism, progress, democracy, and science, and initiated the New Democratic Revolution in China, contributing to the spread of Marxism in China, as well as laying the foundations for the founding of the $\mathrm{CCP}^{\prime \prime 3}$. Given the achievements of the May 4 Movement, the present power of the PRC does not remain passive. A few days before the celebration of the 100th anniversary of the movement, the current leader of China, the President of the PRC, and the secretarygeneral of the $\mathrm{CCP}$, Xi Jinping, during a meeting with young activists of the party, indicated that "young people should be grateful to the party, the country, and society, and patriotism is a duty" he explained that at present patriotism is devotion to socialism, love for the country and the party ${ }^{64}$. The leader of China is trying to shape the attitudes of Chinese youth, using the entire bureaucratic, propaganda, and educational apparatus, justifying: "To continue to use the spirit of the May 4 Movement and to help undertake the great task of rebuilding the nation, [youth] must thoroughly understand the principle of the Six Hopes described by Chairman Xi Jinping. "The six principles are the formation of far-reaching ideals; zealous love for the motherland; taking responsibility at your age; readiness to fight; self-improvement and the ability to improve morals ${ }^{65}$. In a word, nothing can happen without the will and consent of Xi Jinping. In this con-

63 Xi Jinping, Zarzadzanie Chinami, vol. I, Toruń 2019, p. 206.

64 Jiayang Fan, Xi Jinping Tries to Crash the May Fourth Movement's Centenary, https://www.newyorker.com/news/daily-comment/ xi-jinping-tries-to-crash-the-may-fourth-movements-centenary [access: 19.07.2019].

65 R. Tomański, Sto lat temu Chiny mogty stać się całkowicie innym państwem. I świat nie byłby taki sam, https://businessinsider.com.pl/ wiadomosci/setna-rocznica-ruchu-4-maja-wybiorcza-pamiec-o-studenckich-protestach/8rrpqtp [access: 19.07.2019]. 
text, the protests in Hong Kong seem to stand no chance of confronting the radicalism of the authorities, which will certainly not hesitate to use disproportionate forces, as indicated by reports of an increase in the number of troops in Hong Kong, and especially by the authorities' announcements that it is necessary to "adopt a harder line to restore order"66. One hundred years after the May 4 Movement, the government in China is again taking action against the citizens, taking radical measures against the apologists for democracy, freedom, and civil rights ${ }^{67}$. Although Xi Jinping indicates the influence of the May 4 Movement on shaping such values in Chinese society as "prosperity, democracy, civilized life, harmony, freedom, equality, justice, the rule of law, patriotism, sacrifice, honesty, friendship"68, their meaning is different from the democratic-liberal principles of the Western world, which them a specifically Chinese meaning.

\section{Bibliography}

Bayer J., Dziak W.J., Historia polityczna Chin 1839-2014. Konspekt analityczny, Warsaw 2016.

Bayer J., Dziak W.J., Historia polityczna Chin 1839-2014. Kronika najważniejszych wydarzeń, Warsaw 2015. Bendiner E., Czas aniołów. Tragikomiczna historia Ligi Narodów, Warsaw 1981.

66 Chińska armia ostrzega protestujących, https://www.tvn24.pl/ wiadomosci-ze-swiata,2/protesty-w-hongkongu-garnizon-chinskiej-armii-ostrzega-demonstrantow,975233.html [access: 10.10.2019].

67 Xi Jinping zabrat głos w sprawie niepokojów w Hongkongu, https:// www.tvn24.pl/protesty-w-hongkongu-xi-jinping-wezwal-do-zakonczenia-przemocy-i-chaosu,982882,s.html [access: 8.11.2019].

68 Xi Jinping, op.cit., p. 210. 
Burlingas I., Stosunki międzynarodowe na Dalekim Wschodzie w latach 1904-1914, [in:] Historia polityczna Dalekiego Wschodu od końca XVI w do 1945 r., eds. J. Żukow, M. Sładkowski, A. Dubinski, Warsaw 1981.

Chińska armia ostrzega protestujących, https://www.tvn24.pl/ wiadomosci-ze-swiata,2/protesty-w-hongkongu-garnizonchinskiej-armii-ostrzega-demonstrantow,975233.html.

Chwostow W.M., Walka dyplomatyczna w okresie pierwszej wojny światowej, [in:] Historia dyplomacji 1914-1939, vol. III, eds. A.A. Gromyko et al., Warsaw 1973.

Dikotter F., Rewolucja kulturalna. Historia narodu 1962 $\neq$ -1976, Wołowiec 2018.

Dmochowski T., Interwencja mocarstw na Syberii i Dalekim Wschodzie (1918-1922), Toruń 2000.

Dmochowski T., Rewolucja 1917 r. w strefie wywtaszczonej kolei wschodniochińskiej w Harbinie, „Gdańskie Studia Azji Wschodniej” 2015, no. 8.

Epstein I., Rewolucja w Chinach trwa, Warsaw 1949.

Fairbank J.K., Historia Chin. Nowe spojrzenie, WarsawGdańsk 2003.

Fenby J., Chiny. Upadek i narodziny wielkiej potęgi, Kraków 2009.

Gacek Ł., Rola konfucjanizmu w ksztattowaniu ideologii państwowej w Chinach $w$ XX wieku, „Krakowskie Studia Międzynarodowe" 2015, no. 3.

Gawlikowski K., Nowa batalia o Konfucjusza, Warsaw 1976. Głunin W.I., Przypływ ruchu narodowowyzwoleńczego w Chinach (1917-1924), [in:] Najnowsza historia Chin (1917-1976), eds. G.W. Astafiew, W.N. Nikiforow, M.I. Sładkowskij, Warsaw 1976.

Góralczyk B., Pekińska wiosna 1989. Początki ruchu demokratycznego w Chinach, Warsaw 1999. 
Góralczyk B., Rewolucja Xinhai w chińskich dziejach, „Azja-Pacyfik" 2011, vol. XIV.

Góralczyk B., Sun Yat-sen. Misjonarz rewolucji, Warsaw 2013. Góralczyk Z., Komunistyczna Partia Chin a Stany Zjednoczone (lipiec 1921-czerwiec 1950), Warsaw 1981.

Halik T., Powstanie „Yihetuan” (1898-1901), [in:] Nowożytna historia Chin, ed. Roman Sławiński, Kraków 2005.

Halik T., Reformatorzy i rewolucjoniści, [in:] Nowożytna historia Chin, ed. Roman Sławiński, Kraków 2005.

Halik T., Stosunki Chin z obcymi mocarstwami od potowy XIX w. do lat 30. XX w., [in:] Nowożytna historia Chin, ed. R. Sławiński, Kraków 2005.

Haapanen J., Adaptation to World Trends. A Rereading of the May Fourth Movement Radicalization, Juvaskyla 2013.

Hayford C.W., Literacy Movement in Modern China, https:// www.researchgate.net/publication/300450509_Literacy_ Movements_in_Modern_China.

https://chineseposters.net/posters/e15-575.php. https://pl.wikipedia.org/wiki/Kinmochi_Saionji. https://www.britannica.com/biography/Ronglu. Jefimow G., Wielka Socjalistyczna Rewolucja Październikowa a Daleki Wschód. Konferencja waszyngtońska, [in:] Historia polityczna Dalekiego Wschodu od końca XVI w do 1945 r., eds. J. Żukow, M. Sładkowski, A. Dubinski, Warsaw 1981.

Jefimow G., Zarys nowożytnej $i$ wspótczesnej historii Chin, Warsaw 1953.

Jiayang Fan, Xi Jinping Tries to Crash the May Fourth Movement's Centenary, https://www.newyorker.com/news/ daily-comment/xi-jinping-tries-to-crash-the-may-fourth-movements-centenary. 
Jones S., The Fourteen Points of Woodrow Wilson's Plan for Peace, (7.07.2019), https://www.thoughtco.com/the-fourteen-points-3310117.

Kissinger H., Dyplomacja, Warsaw 2002.

Koetse M., Gendered Nationalism and May Fourth: China's "New Woman", https://www.manyakoetse.com/gendered-nationalism-and-may-fourth-chinas-new-woman/.

Konior J., Historia Kościoła w Chinach. Wyzwania, obawy i nadzieje (od nestorianizmu do czasów wspótczesnych), Kraków 2019.

Król A.I., Chiny w latach 1898-1937 - między artystyczna tradycja a sztuka Zachodu, Warsaw-Toruń 2016.

Kukowski M., Proces przyjęcia i odrzucenia japońskiego wzoru przez Chiny. Od końca XIX wieku do 1937 roku, https://mysl.lazarski.pl/fileadmin/user_upload/dokumenty/czasopisma/mysl-ekonomiczna-polityczna/2014/ MEiP_1_7_2014_Kukowski.pdf.

Levy J.S., The first Word War: causes, consequences, and controversies, https://fas-polisci.rutgers.edu.

Li Dazhao, https://pl.wikipedia.org/wiki/Li_Dazhao.

Ławacz M., Sun Yat-sen - życie i działalność, [in:] Trzy zasady ludu, ed. Sun Yat-sesn, Warsaw 1914.

Łukasik P., Impuls Wilsona - Stany Zjednoczone w I wojnie światowej, "Ante Portas - Studia nad Bezpieczeństwem" 2015, no. 1.

Malicka A. (ed.), Najnowsza historia Chin, Warsaw 1954.

MacMillan M., Paryż 1919. Sześć miesięcy, które zmienity świat: konferencja pokojowa w Paryżu w 1919 roku i próba zakończenia wojny, Oświęcim 2018.

Marshall G.C., Memoirs of My Services in the World War 1917-1918, Boston 1976. 
Materski W., Bolszewicy i samuraje. Walka dyplomatyczna i zbrojna o rosyjski Daleki Wschód (1917-1925), Warsaw 1990.

Mencel M.T., Chińska Republika Ludowa jako wspótczesny podmiot środowiska międzynarodowego, vol. I Uwarunkowania, Toruń 2016.

Mencel M.T., Chińska Republika Ludowa jako wspótczesny podmiot środowiska międzynarodowego, vol. II Wektory, Toruń 2016.

Mencel M.T., Chińska Republika Ludowa jako wspótczesny podmiot środowiska międzynarodowego, vol. III Rozważania o rzeczywistości, Toruń 2016.

Mencel M.T., Kobieta w Chinach: kulturowa przeszłość i teraźniejszość, [in:] Kobiety w życiu kulturowym Polski $i$ świata, eds. A. Chodubski, A. Frączek, B. Słobodzian, Gdańsk 2012.

Mencel M.T., Wiejski charakter chińskiego społeczeństwa, [in:] Chińska Republika Ludowa jako wspótczesny podmiot środowiska międzynarodowego, vol. III Rozważania o rzeczywistości, ed. M.T. Mencel, Toruń 2016.

Mierzejewski D., Wyzwania chińskiej dyplomacji u progu ery republikańskiej, „Azja-Pacyfik” 2011, vol. XIV.

Minc I.I., Zwycięstwo koalicji nad Niemcami i ich sprzymierzeńcami, [in:] Historia dyplomacji 1914-1939, vol. III, eds. A.A. Gromyko et al., Warsaw 1973.

Mitter R., Gorzka rewolucja. Zmagania Chin z nowoczesnym światem, Warsaw 2008.

Morton W.S., Lewis C.M., Chiny. Historia i kultura, Kraków 2007.

Odtajniony RAPORT ws. masakry na placu Tiananmen: 10 tysięcy ofiar. DRASTYCZNE OPISY, https://wiadomosci.dziennik.pl/swiat/artykuly/565333,chiny-10-tys- 
-ofiar-na-placu-tiananmen-wedlug-odtajnionego-dokumentu.html.

Osterhammel J., British business ich China, 1860s-1950s, Cambridge 1989.

Pajor J., Chiny w polityce zagranicznej Stanów Zjednoczonych w latach 1911-1918, Łódź 2019.

Pietraszak M., Dacyszen W., Regionalny aspekt historii stosunków rosyjsko-chińskich, Łódź 2012.

Plesiewicz-Świerczyńska I., Wykładnie ideologiczne stosunków japońsko-amerykańskich w latach 1853-1941 oraz ich implementacja polityczna, Praca doktorska, Uniwersytet Łódzki Wydział Studiów Międzynarodowych i Politologicznych, Łódź 2017, https://kipdf.com/ queue/uniwersytet-odzki-wydzia-studiow-midzynarodowych-i-politologicznych-izabela-ples_5b35197b097c47886d8b4b18.html.

Polit J., Japonia wobec rewolucji bolszewickiej w Rosji, 1917-1922, „Dzieje Najnowsze” 2017, vol. XLIX, no. 4.

Polit J., Mocarstwa wobec rewolucji Xinhai, „Azja-Pacyfik” 2011, vol. XIV.

Polit J., Wojny chińskich warlordów 1916-1928, Zabrze-Tarnowskie Góry 2017.

Rodziński W., Chiny w ogniu. Rewolucja w latach 1925-1927, Wrocław-Warsaw-Kraków-Gdańsk-Łódź 1983. Rodziński W., Historia Chin, Wrocław-Warsaw-Kraków 1992.

Rojek W., Spory o wtadanie morzem. Polityczno-dyplomatyczne aspekty zbrojeń morskich w okresie międzywojennym 1919-1939, Kraków 1994.

Saveliev I.R., Pestushko Y.S., Dangerous Rapprochement. Russia and Japan in the First World War, 1914-1916, https://www.semanticscholar.org/paper/Dangerous-Rap- 
prochement-\%3A-Russia-and-Japan-in-the-Saveliev-Pestushko/9ce90eb43425cdf9c705a555f4e9db2f32d571e2. Sierpowski S., Narodziny Ligi Narodów. Powstanie, organizacja $i$ zasady działania, Poznań 1984.

Skřivan A. Jr. , Skřivan A. Sr., Great Powers and the Sino-Japanese War 1894-1895, http://cejsh.icm.edu.pl/cejsh/ contributor/9166dddb9ad73f6de6e47e7d2f444b0d.

Sładkowski M., Chiny i Japonia, Warsaw 1975.

Sładkowski M., Pierwsza wojna światowa i Daleki Wschód (1914-1918), [in:] Historia polityczna Dalekiego Wschodu od końca XVI w do 1945 r., eds. J. Żukow, M. Sładkowski, A. Dubinski, Warsaw 1981.

Sławiński R., „Nowy” konfucjanizm w krajach Azji Wschodniej, „Krakowskie Studia Międzynarodowe” 2010, no. 1. Sławiński R., Yuan Shikai i rządy militarystów. Wyprawa pótnocna i zjednoczenie kraju, [in:] Nowożytna historia Chin, eds. R. Sławiński, Kraków 2005.

Sokala P., Liga Narodów - globalny diler zasad i wyjątków? Historyczne znaczenie organizacji w perspektywie historii Chin, [in:] Liga narodów wybranych, eds. M.F. Gawrycki, A. Bógdał-Brzezińska, Warsaw 2010.

Tomański R., Sto lat temu Chiny mogty stać się całkowicie innym państwem. I świat nie bytby taki sam, https://businessinsider.com.pl/wiadomosci/setna-rocznica-ruchu-4-maja-wybiorcza-pamiec-o-studenckich-protestach/8rrpqtp. Treaty of Shimonoseki, http://www.taiwandocuments.org/ shimonoseki01.htm.

Tychwinski S.L. (ed.), Historia nowożytna Chin, Warsaw 1979.

Wasserstrom J., Liu Xinyong, Student protest and student life: Shanghai, 1919-49, https://www.jstor.org/stable/428 5735 ?seq=1\#page_scan_tab_contents. 
Robert W., Woodrow Wilson's Fourteen Points, https://www. thoughtco.com/woodrow-wilsons-fourteen-points-1222 054.

Woodrow W., Kształtowanie losów świata. Pamiętniki i dokumenty, vol. 1, Warsaw 1924.

Xi Jinping zabrał głos $w$ sprawie niepokojów w Hongkongu), https://www.tvn24.pl/protesty-w-hongkongu-xi-jinping-wezwal-do-zakonczenia-przemocy-i-chaosu,982882,s. html.

Xi Jinping, Zarzadzanie Chinami, vol. I, Toruń 2019.

Xinzhong Yao, Konfucjanizm. Wprowadzenie, Kraków 2009. Yang Chunmei, The May Fourth Movement in Chinese History. To understand the May Fourth Movement, we must first understand its ideological roots, https://www. sixthtone.com/news/1003904/the-may-fourth-movement-in-chinese-history.

\begin{abstract}
The $100^{\text {th }}$ anniversary of the events prompts us to consider the proper causes of the outbreak of the May 4 Movement and its impact on the shaping of internal social relations and changes taking place in the Chinese socio-political space. The considerations presented in this lecture are mainly focused on a synthetic approach to the issues of changes taking place in the international environment, especially the policy of great powers towards China, and the phenomena taking place in Chinese society, of which the May 4 Movement was a consequence. The area of analysis is marked by the fields of internal relations and social changes taking place in China after the overthrow of feudal authoritarianism, as well as the increase in social-political awareness, social interest in socialism and communism, the rise of nationalism, and the creation of the foundations of civil society, rejection of the Confucian tradition and retreat to Confucian patterns. The impact of the May 4 Movement goes far beyond the Marxist
\end{abstract}


ideological and doctrinal approach, which is reflected in contemporary events in China, where the Chinese intelligentsia became the main actors, just like in 1919.

Keywords: China, May 4 Movement, Movement for New Culture, communism, civil society, Confucianism, nationalism, emancipation, feminism

\begin{abstract}
Abstrakt
100-letnia rocznica wydarzeń daje asumpt do podjęcia rozważań mających na celu ustalenie właściwych przyczyn wybuchu Ruchu 4 Maja i jego wpływu na kształtowanie wewnętrznych stosunków społecznych i zmiany zachodzące w chińskiej przestrzeni społeczno-politycznej. Rozważania przedstawione w niniejszym wykładzie skoncentrowano głównie na syntetycznym ujęciu problematyki zmian zachodzących w środowisku międzynarodowym, zwłaszcza polityki mocarstw wobec Chin oraz zjawiskach zachodzących w chińskim społeczeństwie, których Ruch 4 Maja był konsekwencją. Obszar analizy wyznaczają pola obejmujące stosunki wewnętrzne i przemiany społeczne zachodzące w Chinach po obaleniu autorytaryzmu feudalnego, oraz wzrost społecznej świadomości politycznej, społecznego zainteresowania socjalizmem i komunizmem, wzrastanie narodowego nacjonalizmu oraz tworzenie zrębów społeczeństwa obywatelskiego, odrzucenie tradycji konfucjańskiej i odwrót do konfucjańskich wzorców. Siła oddziaływania Ruchu 4 Maja daleko wykracza poza marksistowskie ujęcie ideologiczno-doktrynalne, czego wyrazem są współczesne wydarzenia w Chinach, których głównymi aktorami, podobnie jak w 1919 r., stała się chińska inteligencja.
\end{abstract}

Słowa kluczowe: Chiny, Ruch 4 Maja, Ruch na rzecz Nowej Kultury, komunizm, społeczeństwo obywatelskie, konfucjanizm, nacjonalizm, emancypacja, feminizm 


\section{Beata Pietkiewicz-Pareek}

University of Wroclaw

ORCID ID: https: / /orcid.org/0000-0001-8450-1707

\section{Remote Education in India during the COVID-19 Pandemic}

\section{Introduction}

The COVID-19 pandemic has forced schools to close, and traditional education has to be reorganized worldwide. Never in the history of education have we dealt with mass school closings and a shift to remote education. Never in history have we been forced not to leave the house, to stop meeting family, friends, and even the closest neighbors. The new situation in the global society forced us to take new measures, to think about what educational procedures should look like during this COVID-19 pandemic period. So far, no one has provided the proper solution for this challenge. That is why the academic community worldwide must face this problem and develop new standards for distance (remote) education. Remote education is not easy without the child's direct contact with the teacher, without access to the Internet, computer, or even without access to electricity. India is one of the leading countries affected by the coronavirus, with over 10 million people falling ill by the end of December 2020, of which over 152,000 have died. It puts India in second place globally in terms of COVID-19 incidence, after the United States. 
This article helps Polish readers from the educational sectors understand the Indian education system during the pandemic. The paper discussed the struggle of Indian people in the society with limitations such as the inability to establish direct contact between the teacher and the student, the lack of Internet access, the lack of access to libraries and teaching aids, the lack of access to school infrastructure, as well as the inability to use direct help of peers. The Indian government is trying to improve the existing educational programmes and create new ones based on resources available to India's poorest people. It is done to avoid children dropping out of school and minimize the gap between poor and rich Indian communities.

\section{Distance Learning in India}

More than 320 million students have been forced to stay at home in India after the government announced shutting down schools due to the coronavirus (COVID-19) pandemic on March 11, 2020. The introduction of remote classes began immediately, forgetting that most citizens do not have access to the Internet or even electricity, not to mention that having a computer is an unattainable dream for them. According to data from July 2020, only $50 \%$ of the Indian population had access to the Internet, which means that out of over a billion people, only 560 million have Internet access. It is significant progress if we consider that in 2007 only $4 \%$ of the population had access to the Internet. Access to the Internet in India depends on factors such as gender and social status. In 2019, about 290 million users were from rural regions, and 337 million from urban areas had access to the 
Internet. Most of the users are between the ages of 20 and 29 . They logged in mainly from cell phones. The possibility of using cheap Internet is an advantage factor, thanks to the Digital India campaign, which aims to provide $4 \mathrm{G}$ internet to all rural regions of India. Facebook is the most popular social media in India, with over 280 million users ${ }^{1}$.

Developing distance/remote learning programs requires time, specialists, and usually some financial resources. Educational institutions in India that have previously conducted remote classes are well-prepared for the time of the COVID-19 pandemic to continue their teaching jobs. However, the institutions that have never dealt with remote education on a mass scale, and teachers are not equipped with even the most straightforward equipment for conducting online classes, are worse affected their teaching jobs. Currently, education in India is facing three challenges to ensure continuity of education in school. First, education is an ongoing process in India. In order to gain knowledge, the student must first pass one examinational test, then another, etc. One cannot skip anything of examinational tests. Secondly, they must ensure that all learners have access to the materials they are about to use. No student can be left out of access to education. Not everyone has to have online classes, but everyone must have books, notebooks, or other materials that often are left in schools closed overnight. Thirdly, perhaps most importantly, the child's well-being should be considered. Isolation and lack of contact with peers or family have affected children negatively. In these difficult times, we should all remember this.

1 https://statista.com/topics/2157/internet-usage-in-india/ [access: 30.12.2020]. 


\section{Key Factors Involved During Synchronous and Asynchronous Communications}

According to World Bank, the COVID-19 pandemic is a stress test for education systems around the world. Due to the crisis, 190 countries have faced complete or partial school closures, and as a result, more than 1.7 billion students have been affected. With hundreds of millions of learners forced to stay home, education policymakers are working to ensure that classes continue and that the most vulnerable do not get left behind. Technology is one of the most critical tools to support remote learning when learners need to remain outside classrooms. With many different approaches being taken by countries worldwide, the $\mathrm{CO}$ VID-19 crisis is an opportunity for policymakers to learn from each other and co-operate to mitigate the effects of the pandemic and maybe even "build back better" 2 .

The most popular platforms used by Indian teachers in synchronous education (Table 1) are the Zoom and Microsoft Teams online meeting platforms. However, the use of the Microsoft Team platform is limited because not every student has an e-mail account on Outlook. Therefore, as an alternative, they use the free version of the Zoom online meeting platform. The teacher creates an event and invites students to it by sending them the meeting password.

For the teachers, asynchronous teaching provides an opportunity to prepare materials and send them at a convenient time to students, and students to solve tasks when

2 https://www.worldbank.org/en/topic/edutech/brief/lessons-foreducation-during-covid-19-crisis [access: 30.12.2020]. 
they have time. It provides convenience to both teachers and students to conduct the teaching and learning tasks with more freedom and work on the new materials and technologies.

Several key factors involved during the synchronous and asynchronous communications viz., interaction, technologies, learning management system, instructors/teachers, learners/students, and homework/assignments were explained and illustrated in detail in Table 1.

Table 1. Advantages and disadvantages of synchronous and asynchronous educational programmes

\begin{tabular}{|c|c|c|c|c|}
\hline \multirow{2}{*}{ 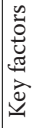 } & \multicolumn{2}{|c|}{ Mechanical synchronous education } & \multicolumn{2}{|c|}{ Asynchronous education } \\
\hline & Advantages & Disadvantages & Advantages & Disadvantages \\
\hline 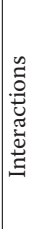 & $\begin{array}{l}\text { Real-time interac- } \\
\text { tions and online } \\
\text { meetings with the } \\
\text { teachers and class } \\
\text { students, no isola- } \\
\text { tion and no feeling } \\
\text { of loneliness }\end{array}$ & $\begin{array}{l}\text { Coordination with } \\
\text { teacher online } \\
\text { ZOOM or MS } \\
\text { Teams meetings and } \\
\text { attendance all at the } \\
\text { same time. Lack of } \\
\text { student-to-student } \\
\text { interactions. }\end{array}$ & $\begin{array}{l}\text { The teacher and } \\
\text { students can initiate } \\
\text { a conversation } 24 / 7 \\
\text { using various tools } \\
\text { such as e-mail, } \\
\text { forum, chat. }\end{array}$ & $\begin{array}{l}\text { The answer does not } \\
\text { come immediately. } \\
\text { One has to wait, } \\
\text { which leads to } \\
\text { breaks in commu- } \\
\text { nication with the } \\
\text { teacher or students, } \\
\text { which disturbs the } \\
\text { dialogue. }\end{array}$ \\
\hline 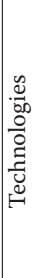 & $\begin{array}{l}\text { Live audio/video ses- } \\
\text { sions require specific } \\
\text { hardware }\end{array}$ & $\begin{array}{l}\text { It requires advanced } \\
\text { technology, access to } \\
\text { high-speed Internet, } \\
\text { a webcam, which } \\
\text { not every student or } \\
\text { teacher can afford. } \\
\text { Sometimes there is } \\
\text { one computer per } \\
\text { family. }\end{array}$ & $\begin{array}{l}\text { Smaller hardware re- } \\
\text { quirements. Pictures } \\
\text { of the completed } \\
\text { activities can be sent } \\
\text { by text message at } \\
\text { any time of the day } \\
\text { or night. } \\
\text { At night, the Inter- } \\
\text { net is faster, so one } \\
\text { can transfer larger } \\
\text { files. }\end{array}$ & $\begin{array}{l}\text { Technical problems } \\
\text { lead to frustration } \\
\text { not only of teachers } \\
\text { and students but } \\
\text { also of parents. They } \\
\text { often prevent partic- } \\
\text { ipation in classes. }\end{array}$ \\
\hline 岂 & $\begin{array}{l}\text { The teacher } \\
\text { functions according } \\
\text { to the timetable, } \\
\text { organizes meetings } \\
\text { in the application, } \\
\text { improves his compe- } \\
\text { tences, prepares ma- } \\
\text { terials and education } \\
\text { content adequate } \\
\text { to the pandemic } \\
\text { situation. }\end{array}$ & $\begin{array}{l}\text { The teacher must } \\
\text { be prepared to deal } \\
\text { with the inability } \\
\text { to contact students } \\
\text { for reasons beyond } \\
\text { their control and } \\
\text { must therefore have } \\
\text { a contingency plan. } \\
\text { It requires extra time }\end{array}$ & $\begin{array}{l}\text { The material is } \\
\text { prepared in advance } \\
\text { and sent to students } \\
\text { at any time. }\end{array}$ & $\begin{array}{l}\text { Coordinating the } \\
\text { work of students } \\
\text { is difficult because } \\
\text { everyone sends back } \\
\text { the completed tasks } \\
\text { at any time. He is } \\
\text { not sure who made } \\
\text { them. }\end{array}$ \\
\hline
\end{tabular}




\begin{tabular}{|c|c|c|c|c|}
\hline 䓪 & $\begin{array}{l}\text { The student has con- } \\
\text { tact with the teacher } \\
\text { and peers, thanks to } \\
\text { which he does not } \\
\text { feel isolated. }\end{array}$ & $\begin{array}{l}\text { The student is forced } \\
\text { to follow the time- } \\
\text { table. If he fails to re- } \\
\text { unite with the group, } \\
\text { he will miss the class } \\
\text { and will have to do it } \\
\text { somehow. }\end{array}$ & $\begin{array}{l}\text { The student can } \\
\text { work on their own, } \\
\text { at any time conven- } \\
\text { ient for them. Sends } \\
\text { completed tasks and } \\
\text { gets feedback. }\end{array}$ & $\begin{array}{l}\text { The student may } \\
\text { cheat the teacher } \\
\text { and send lessons } \\
\text { done by parents or } \\
\text { peers. }\end{array}$ \\
\hline 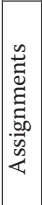 & $\begin{array}{l}\text { The tasks are provid- } \\
\text { ed regularly, and the } \\
\text { teacher can evaluate } \\
\text { their implementa- } \\
\text { tion quickly, being } \\
\text { sure who performed } \\
\text { them. }\end{array}$ & $\begin{array}{l}\text { It is difficult to } \\
\text { check a dozen works } \\
\text { through a webcam } \\
\text { in a short time. They } \\
\text { must be sent by } \\
\text { e-mail, text message, } \\
\text { or using another } \\
\text { communicator. }\end{array}$ & $\begin{array}{l}\text { Tasks can be pre- } \\
\text { pared in the form of } \\
\text { quizzes, games, or } \\
\text { other activities that } \\
\text { students can solve at } \\
\text { any time. }\end{array}$ & $\begin{array}{l}\text { Strangers may } \\
\text { perform tasks. The } \\
\text { teacher has no way } \\
\text { of controlling who } \\
\text { has performed them. }\end{array}$ \\
\hline
\end{tabular}

Source: Z.D. Mulla, V. Osland-Paton, M.A. Rodriguez, E. Vazquez, S. Kupesic Plavsic, Novel coronavirus, novel faculty development programs: rapid transition to eLearning during the pandemic, "Journal of Perinatal Medicine” 2020, vol. 48, no. 5, pp. 446-449.

\section{Remote Learning Initiatives in India}

Online applications help students access teaching materials and allow them to participate in classes and interact with teachers, much like classroom lectures. The following is a list of government of India initiatives launched to improve distance learning during the pandemic. Firstly, to involve teachers in the fight against the COVID-19 pandemic, the Indian government launched a training module called "Integrated Government Online Training for government employees" (IGOT). The program aimed to increase government employees' capacity to effectively deal with the educational courses during the COVID-19 pandemic. The educational courses have been launched not only for teachers but also for doctors, nurses, state government officials, officials, police, volunteers, and other frontline people in the fight against the coronavirus. The platform is designed to train teachers online, prepare them to conduct remote education, prepare quizzes, perform educational activities to promote creativ- 
ity and critical thinking and ensure continuity of teaching related to the implementation of the curriculum today. Educational materials on the portal can be obtained after logging in to the platform using only a mobile phone ${ }^{3}$.

The Social Media Interface for Learning Engagement (Smile) platform is an innovative program of the Department of School Education in Rajasthan, which aims to provide remote education to students staying at home in the wake of the coronavirus pandemic. The municipal council or village administrator (Gram Panchayat) receives selected educational materials, which are then passed on to the parents of the students. Smile platform also effectively uses social media and WhatsApp on an unprecedented scale. They enable contact with parents and the multi-faceted development of students confined to home due to the pandemic. An important role in distributing educational materials is played by the administrator, i.e., an official in the Municipal Council, because he is responsible for providing educational materials via WhatsApp. For this purpose, two groups of recipients of educational aids were created: teachers and parents. Parents play a critical role in the Smile program, as they are the ones who have to pass the materials received on the mobile phone to their children. As a result, they are aware of what content their children receive every day. They can interfere with their home education, control their progress, and expand their knowledge with new messages. Currently, educational materials are created and selected in a state context, and in the future, they will be developed based on state curricula. Teachers are active partners in the process of creating educational materials. Their role is to actively help students,

3 https://igot.nic.in/ [access: 30.12.2020]. 
observe and analyze their progress in independent learning. They also prepare and send materials to parents and record videos. Thanks to the effective implementation of the Smile Program, Rajasthan can benefit enormously in providing education to students in times of a pandemic. The content currently reaches students in 1278000 households via 9226 WhatsApp groups and 328000 teachers via 9768 WhatsApp groups every day ${ }^{4}$.

The Study Webs of Active-Learning for Young Aspiring Minds (SWAYAM: Hindi word means "Self") platform provides access to courses organized by Indira Gandhi National Open University (IGNOU) and Ministry of education, New Delhi, India. Under this program, high-quality teaching materials posted on the platform allow students to gain knowledge on the subject of their interest within a few months. Course participants gain access to texts, videos, and a discussion forum, and at the end of the course, they receive a certificate. The Government of India initiated the SWAYAM programme to ensure the three main principles of education policy: Accessibility, Equality, and Quality. These activities aim to make the best quality teaching materials available to all, especially those outside the mainstream knowledge-based economy.

Most importantly, all courses are free, and participants can choose the time to complete them themselves ${ }^{5}$. Moreover, the SWAYAM PRABHA TV platform consists of $34 \mathrm{TV}$ channels with 24/7 access, presenting new teaching materials every 4 hours. On each channel, children and adolescents can

4 https://vikaspedia.in/education/education-best-practices/remote-learning-initiatives-in-india/remote-learning-initiatives-in-rajasthan [access: 30.12.2020].

5 https://swayam.gov.in/about [access: 30.12.2020]. 
attend classes. Each channel is assigned to a different class; each class has a weekly timetable. Thanks to this, children without access to the Internet can get help in learning new material. Classes are carried out, following the core curriculum for each class. This type of remote education is prevalent in India, and for many, it is the only way to maintain the continuity of education ${ }^{6}$.

E-Pathshala mobile app is available through an especially developed mobile app interface on Android, iOS, and Windows platforms for broader access. It contains textbooks and other e-books as E-Pub 3.0 and Flipbooks in English, Hindi, and Urdu. The digital India campaign has promoted the extensive use of ICTs in the teaching-learning process. The ePathshala, a joint initiative of the Ministry of Human Resource Development (MHRD), Govt. of India, and National Council of Educational Research and Training (NCERT), has been developed for showcasing and disseminating all educational eresources, including textbooks, audio, video, periodicals, and a variety of other print and non-print materials for Students, Teachers, Parents, researchers, and educators. It provides access to digital textbooks for all classes, graded learning materials and enables participation in exhibitions, contests, festivals, workshops, etc. Students, teachers, educators, and parents can access eBooks through multiple technology platforms, including mobile phones and tablets, and from the web through laptops and desktops. ePathshala also allows users to carry as many books as their device supports. Features of these books allow users to pinch, select, zoom, bookmark, highlight, navigate, share and make notes digitally ${ }^{7}$

6 https://www.swayamprabha.gov.in/ [access: 30.12.2020].

7 https://vikaspedia.in/education/interactive-resources/e-pathshala [access: 30.12.2020]. 


\section{Distance Learning During the Pandemic as Perceived by Students and Teachers}

In the early stages, right after the schools closed in the COVID-19 pandemic, the students felt happy because they had more time to play and other activities at home. However, when they realized the confusion of the limitations, their contentment turned into fear for the future. The opinions of the students themselves dominated the feeling of loneliness. Most of the children found it difficult to adapt to the new conditions. They were unable to connect to the teacher due to the availability of poor or no Internet. The children stopped learning systematically, and the parents did not have the time or the skills to help them catch up. After some time, some of the children broke off contact with the teacher. They did not have the technical ability to contact the teacher online, and some of the parents did not have access to modern smartphones to send back their homework by text message. As the pandemic suddenly broke out, neither the teachers nor the children could prepare for the classes at home. Teachers, like children, did not have access to high-quality technology and the Internet. As a result, some teachers limited themselves to sending homework to be done via text messages. It caused great dissatisfaction not only among the students themselves but also their parents. After switching to remote synchronous education, teachers observed meager attendance among students during classes. Poor picture quality and sound make interaction difficult ${ }^{8}$.

8 P.K. Jena, Online learning during lockdown period for COVID-19 in 
According to Oxfam India Report on education during the lockdown, the use of WhatsApp, access continues to be an issue. Over $75 \%$ of parents reported a host of challenges in supporting children to access education digitally, including 1) not having an internet connection, 2) being unable to afford data, 3) Internet speed/signal is not conducive. While these challenges were common across states, in Jharkhand specifically, over $40 \%$ of parents reported that they did not have the correct device to access digital education. Interestingly, these findings are similar to those of private schools, where parents reported internet speed and signal as the main hindrances in accessing online learning. Despite challenges in accessing education digitally, not a single instance of education through non-digital mediums was reported. Due to the continued reliance on digital modes and the interrupted access to education, it is estimated that children from disadvantaged backgrounds will lose almost $40 \%$ of their previous year's learning'.

\section{Digital Exclusion}

Education technology was on the rise even before COVID-19 and is now even more likely to become a permanent feature of schooling systems across the region. Although learning through the Internet can be an effective tool to ensure continuity of education, several risks are involved, particularly for the most financially disadvantaged children. The use of online

India, "International Journal of Multidisciplinary Educational Research" 2020, vol. 9.

9 A. Vyas, Status Report - government and private schools during Covid-19, Oxfam India 2020, pp. 10-12. 
education has exposed the "digital divide" globally, where for many low-income and marginalized families, an internet connection is still considered a luxury ${ }^{10}$.

The lack of availability of digital technology was caused by the uneven spread of modern technological thought around the world. The expansion of IT networks has gained momentum only in highly developed countries while developing countries have lagged far behind. According to A. Jastębska and W. Jastrzębska, the essence of digital exclusion is the division of society into people with access to the Internet and modern telecommunications technologies and those without this possibility ${ }^{11}$. The inability to participate in classes often is due to the lack of access to the device or exclusive equipment. Siblings need to share the computer with their parents. Lack of access to a webcam and printer prevents full participation in classes and preparing materials for classes. A huge problem is limited access to the Internet and its limitations. In many homes, parents are not able to help their children work remotely. They are unable to use a computer or programs for both synchronous and nonsynchronous learning. The apartments lack rooms for everyone to work in silence and privacy.

According to data from Internet World Stats, in 2020, over $90 \%$ of North Americans, $87 \%$ of Europe, $70 \%$ of the Middle East and South America, 59\% of Asians, and 47\% of Africans had access to the Internet ${ }^{12}$. In India in May 2020,

10 https://en.unesco.org/news/covid-19-10-recommendations-plandistance-learning-solutions [access: 30.12.2020].

11 A. Jastrzębska, W. Jastrzębska, Wykluczenie cyfrowe - przyczyny, zagrożenia i bariery jego pokonania. Studium Przypadku, "Nierówności społeczne a wzrost gospodarczy" 2012, no. 25, p. 92.

12 https://www.internetworldstats.com/stats.htm [access: 30.12.2020]. 
out of 1,380,004,385 inhabitants, 560,000,000 were using the Internet ${ }^{13}$. The authors of the UNESCO report said that despite efforts to ensure that all children have access to remote education, as many as 465 million children worldwide do not have access to the Internet and, therefore, education. In many marginalized communities, teachers do not come into contact with up to $90 \%$ of students. The same research shows that $90 \%$ of children during a pandemic have no help at home with school, neither from their parents nor siblings. As a result, they stop learning and contacting teachers ${ }^{14}$. An Oxfam India survey of 1,158 families in five states found that $80 \%$ of government school students and $60 \%$ of private school students received no instruction or educational support during the lockdown ${ }^{15}$.

\section{Other Challenges on Remote Education in India During the COVID-19 Pandemic}

One of India's greatest challenges and other developing countries is ensuring that all girls have equal access to remote education. According to UNESCO data, as many as $10 \%$ of girls are at risk of dropping out of school. The COVID-19 pandemic affects them particularly hard, putting the educational achievements made in recent decades at risk. The pandemic also increases gender-based violence, early marriages, and

13 https://www.internetworldstats.com/stats3.htm [access: 30.12.2020].

14 https://unesdoc.unesco.org/ark:/48223/pf0000373992 [access: 30.12.2020].

15 A. Vyas, Status Report - government and private schools during Covid-19, Oxfam India 2020, pp. 10-13. 
pregnancies, which will effectively prevent girls from continuing their education and getting into a profession in the future $^{16}$. Long before the pandemic outbreak, it was known that stress in the home increased the likelihood of violence and child abuse. By forcing adults and children to spend more time at home during quarantine, the COVID-19 pandemic has led to a sharp increase in domestic violence, becoming in some ways an "invisible epidemic" not only in India but around the world. Movement restrictions give adults even more opportunities to harm children. Isolated from teachers, school friends, social workers, and the safe school space, children lose the ability to report these incidents. At the same time, the inability to earn money, and limited access to work and primary goods and services, provoke additional stress and fuel frustration and aggression. Many families experience economic and food insecurity, prompting them to marry daughters prematurely to reduce the number of people to feed ${ }^{17}$.

It is also crucial to note that as schools reopen, not all students will return. There is overwhelming evidence that the longer children are out of school, the greater the risk of never returning, particularly girls, as numerous studies show. There are 111 million girls living in the world's least developed countries affected by school closures, where getting an education was already a struggle. For many lowincome families, the financial impact of COVID-19 means that many girls may be forced to early marriage or other

16 https://apa.sdg4education2030.org/index.php/building-back-better-girls-education-times-covid-19-asia-pacific [access: 30.12.2020].

17 O. Blomqvist, S. Chughtai, T. Rahman, Covid-19 pandemic lessons from Asia-Pacific. How the region's societies - and their children - can emerge stronger from crisis, Save the children, Londyn 2020, pp. 15-17. 
negative coping strategies made to prioritize domestic work over education, ensuring they will not return to school ${ }^{18}$.

The pandemic has exacted a heavy toll on India's estimated 270 million schoolchildren, who have not seen the inside of a classroom since March - and may not return at all. For decades, India has struggled to entice children into school and teach basic skills, while low-income families have embraced education as a ticket to greater prosperity. Many scraped together the fees for low-cost private schools. COVID-19 has set back those efforts. Elite private schools and top government schools have made a smooth transition to virtual classrooms, though concerns about excessive screen time have curbed instruction.

Nevertheless, millions of less privileged children, including many first-generation pupils, have severely disrupted their education. Neither their families nor their often-rudimentary schools are equipped for remote learning. Longterm school closures also put children at risk of losing skills they had already developed ${ }^{19}$.

\section{Concluding Remarks and the Future Recommendations on Remote Education During COVID-19 Pandemic}

The article highlights the impact of school closure on children in India. According to Oxfam India Report, a third of the students continue to be deprived of Mid-day meals while textbooks have not been received by over $80 \%$ of children. Current modes of education delivery have relied heav-

18 Save the children, COVID-19 Pandemic Lessons from Asia-Pacific, July 2020, p. 11.

19 A. Kazmin, J. Singh, India's schoolchildren pay the price for coronavirus lockdown, Financial Times [access: 11.10.2020]. 
ily on technology, leading to the exclusion of over $80 \%$ of students, who have remained disconnected from education since schools were closed over nine months ago. Interestingly, the challenges of government school children in accessing digital education are similar to those of children in private schools - those of poor internet speed and signal and data being unaffordable, indicating that reliance on digital modes is not an effective solution for anyone. Evidence from the Ebola virus outbreak shows that such prolonged school closure leads to a massive increase in dropouts. It is borne out by the teachers surveyed as well $-40 \%$ of whom believe that a substantial number of children will not return once schools reopen. There is also a real risk of migrant children and those from Dalit and Adivasi communities turning to child labor to support their families economically. The Oxfam India Report also highlights the lack of teacher preparedness and the complete lack of capacity building/ support by state governments to deliver education digitally $-84 \%$ of teachers report challenges in teaching digitally. Further, over half the teachers surveyed believe that lowtech and accessible technology such as radio and physical learning materials is more effective than digital mediums ${ }^{20}$.

1. Online platforms (Zoom, MS Teams, webinar, etc.) should be provided with enhanced security and safeguards, especially virtual learning tools.

2. High-speed internet access should be provided to improve seamless access for all, including learners from disadvantaged groups and low-income families. The Government of India should also provide free electronic devices to all students in poor rural areas and

20 A. Vyas, Status Report - government and private schools during Covid-19, Oxfam India 2020, p. 17. 
marginalized communities. Providing internet access to children from poor households will undoubtedly reduce the digital dividing gap in India.

3. Everyone should follow the new guidelines issued by UNICEF and partners to keep children safe in online activities.

4. Schools should monitor online education when conducting online classes.

5. Parents should work with their children to establish rules about how, when, and where to use the Internet.

6. The government should take the necessary steps to train all education stakeholders on the online learning platform to improve distance learning.

7. Online learning is not open to everyone, including the poor and disadvantaged groups in society. Therefore, governmental and educational institutions should take the necessary steps to minimize this gap between privileged and disadvantaged students.

8. Students and teachers must be familiar with instant messaging services such as e-mail, discussion boards, and chat rooms before joining online classes.

\section{Bibliography}

Blomqvist O., Chughtai S., Rahman T., Covid-19 pandemic lessons from Asia-Pacific. How the region's societies - and their children - can emerge stronger from crisis, Save the children, Londyn 2020.

Jastrzębska A., Jastrzębska W., Wykluczenie cyfrowe - przyczyny, zagrożenia i bariery jego pokonania. Studium Przypadku, "Nierówności społeczne a wzrost gospodarczy" 2012, no. 25. 
Jena P.K., Online learning during lockdown period for COVID-19 in India, "International Journal of Multidisciplinary Educational Research" 2020, vol. 9.

Kazmin A., Singh J., India's schoolchildren pay the price for coronavirus lockdown, "Financial Times", 11.10.2020.

Mulla Z.D., Paton V.O., Rodriguez M.A., Vazquez E., Kupesic Plavsic S., Novel coronavirus, novel faculty development programs: rapid transition to eLearning during the pandemic, "J. Perinat. Med." 2020, vol. 48, no. 5.

Save the children, COVID-19 Pandemic Lessons from AsiaPacific, July 2020.

Vyas A., Status Report - government and private schools during Covid-19, Oxfam India 2020.

\section{Online resources}

https://apa.sdg4education2030.org/index.php/buildingback-better-girls-education-times-covid-19-asia-pacific. https://en.unesco.org/news/covid-19-10-recommendationsplan-distance-learning-solutions [access: 30.12.2020]. https://www.ignou.ac.in.

https://igot.nic.in/.

https://www.internetworldstats.com/stats.htm.

https://www.swayamprabha.gov.in/.

https://www.statista.com/topics/2157/internet-usage-inindia/.

https://swayam.gov.in/about.

https://unesdoc.unesco.org/ark:/48223/pf0000373992.

https://vikaspedia.in/education/education-best-practices/ remote-learning-initiatives-in-india/remote-learninginitiatives-in-rajasthan.

https://www.worldbank.org/en/topic/edutech/brief/lessons-for-education-during-covid-19-crisis. 


\begin{abstract}
For centuries, education in India has relied heavily on traditional teaching methods. The worldwide pandemic has forced schools to close down and prompt distance (remote) learning methods in most educational institutes in India. Because of this, the education system has reorganized the popular traditional teaching and didactics methods by favoring distance learning work. The article is based on the comprehensive analysis of distance learning educational methods during the COVID-19 pandemic period using the online available documents, articles, and reports posted on the Internet and telephone interviews with Indian teachers from March 2020 to December 2020. The article aims to provide the necessary information to the Polish teachers and readers about procedures adopted by the Indian government to improve the teaching process and learning methods during the COVID-19 pandemic period, especially the use of online tools and platforms helpful to conduct the distance learning works. An important element of this research paper is collecting the teachers' opinions on the functioning of distance learning in the schools located in the remote and poorest regions of India.
\end{abstract}

Keywords: e-learning, pandemic, COVID-19, India

\begin{abstract}
Abstrakt
Przez wiele stuleci edukacja w Indiach opierała się przede wszystkim na tradycyjnych metodach nauczania. Pandemia koronawirusa wymusiła zamknięcie szkół i szybkie wdrożenie metod zdalnego nauczania w większości jednostek edukacyjnych w Indiach. $Z$ tego powodu system edukacji doprowadził do reorganizacji tradycyjnych metod nauczania poprzez wsparcie metod zdalnych. Niniejsza praca opiera się na analizie metod nauczania zdalnego podczas pandemii koronawirusa oraz dostępnych dokumentów, artykułów i raportów opublikowanych w Internecie. Wykorzystano również wywiady telefoniczne $\mathrm{z}$ indyjskimi nauczycielami, które były prowadzone od marca do grudnia 2020 r. Celem badania jest zapewnienie niezbędnych informacji polskim czytelnikom z sektora edukacji na temat metod nauczania w dobie pandemii koronawirusa, a szczególnie o narzędziach edukacji zdalnej i platformach edukacyjnych, usprawniających zdalne prowadzenie zajęć dydaktycznych. Ważnym elementem
\end{abstract}


badania jest zebranie opinii nauczycieli na temat skuteczności nauczania zdalnego dzieci uczęszczających do szkół w najuboższych regionach Indii.

Słowa kluczowe: e-learning, pandemia, COVID-19, Indie 


\section{Stanisław Juszczyk}

Silesian University of Technology in Gliwice

ORCID ID: https: / / orcid.org/0000-0002-7775-6303

\section{A Comparative Analysis of Education Cultures in the Republic of Korea and Poland}

\section{Introduction}

Professionals characterize the culture of education differently. It results from cultural differences in their countries of origin. Therefore, defining it often goes back to the ancient philosophies of education, such as Socratic culture in Western European countries and Confucian culture in Asian countries. Accordingly, the culture of education refers to educational systems in different countries, consisting of directives and rules of conduct for people influencing other people and their personality traits (treated in terms of educational and caring attitudes), behavior, or competences. In the first case, it will be deliberately constructed and structured culture of the education system; in the second, the pedagogical culture of the individual(s), including the pedagogical culture of the parents and the culture of behavior. The education system is one of the indicators of education culture level ${ }^{1}$.

1 J. Szczepański, Co rozumiemy przez kulture pedagogiczna?, „Rodzina i Szkoła" 1979, no. 11. 
Developing a culture of education involves shaping educational and caring attitudes related to pedagogical, psychological, sociological, and, to some extent, medical knowledge. It shapes an individual or social group's (e.g., classes) emotions and stimulates socio-educational activity.

The culture of education contains values, norms, and ways of behaving, which result from an awareness of educational objectives and are manifested by the ability of the individual to react in specific educational situations. Therefore, an educator (teacher) should be knowledgeable and aware of education objectives, have an emotional, empathetic, and sympathetic attitude toward other people, especially children, and should act based on understanding of others, especially children or young persons ${ }^{2}$.

The culture of education is dynamic. It is a culture of human behavior, raising awareness of education objectives, developing knowledge about education, and sensitivity to education issues, i.e., children, young people, and adults. The culture of education uses different educational strategies, methods of upbringing and teaching, media instrumentation, methods, and means of communication, including social interactions (in the group, in the classroom), allowing learners to construct knowledge and shape the assumed skills effectively. The concept includes institutions such as kindergartens, schools, and universities, their infrastructure, equipment, teachers' competences, procedures enabling them to update and develop these competences, management methods, which shape the organizational cul-

2 J. Maciaszkowa, Kultura pedagogiczna rodziców, [in:] Pedagogika opiekuńcza. Materiały z Krajowej Konferencji Komitetu Nauk Pedagogicznych PAN, Warsaw 1977. 
ture of the educational establishment. The concepts listed here are further indicators of the culture of education.

Such a normative picture of education culture should ultimately be an optimal construct, disseminated at the level of the local community and then the population of the country concerned and even of many societies where education has common and solid philosophical roots ${ }^{3}$. Accordingly, the process of disseminating the culture of education in the local, i.e., school-family space covers all age categories of educational entities as well as the basic living environments of learners, their parents, educators, teachers, schools, neighborhood groups, adult social organizations, after-school education institutions, the working environment, cultural and educational institutions with a local reach and other environmental institutions. Factors affecting the process of disseminating education culture in the local environment are the socio-occupational structure of family environments, their economic status, the level of culture of the general community of parents, the socio-cultural traditions of the family and school environment, as well as the location of the environment in the area. The main institution implementing the dissemination of the culture of education among learners and parents is the school ${ }^{4}$.

According to Jerome Bruner ${ }^{5}$, the culture of education is a significant issue - especially in contemporary society, namely the post-modern society, and in the XXI century, the post-digital society. Although his reflections engage in

3 S. Juszczyk, Kultura w edukacji. Implikacje społeczne, aksjologiczne i poznawcze, Toruń 2020.

4 M. Winiarski, Rodzina - szkoła - środowisko lokalne. Problemy edukacji środowiskowej, Warsaw 2000.

5 J. Bruner, Culture of Education, Cambridge 1996. 
different confrontations, his position is that we must achieve a deep understanding of the culture of education before we attempt to resolve political issues. Given contemporary debates about school reform, performance standards, and teacher education reform, Bruner's call for reflecting upon fundamental questions about why and how we educate. Moreover, in thinking about what it means to be an educated citizen in a post-digital society, one must grapple with the nature and the importance we ascribe to its different forms. As Bruner points out, in guiding educational reform, we must clearly see directions and face the question of what kind of people we want to be ${ }^{6}$.

These considerations show that different countries have different cultures of education, although they share a common part that results from philosophical systems adopted in their education. Culture affects our perception of self, communication styles, and how we are educated or chose to educate the members of our society. Cultural differences affect teaching and learning styles. Educational strategies and practices in Poland and South Korea seem to contrast like their cultures. Although both cultures recognize education as an important tool for life and educational success, each has a specific view on how educational goals could be achieved ${ }^{7}$.

6 J. Bruner, Culture of Education, "Canadian Journal of Education" 2000, vol. 25, no. 3, pp. 236-238.

7 S. Juszczyk, Y.D. Kim, Confucian Thought Affecting Education in South-East Asian Countries vs. Socratic Education Philosophy in Western Countries, "Athenaeum. Polish Political Science Studies" 2017, no. 56, pp. 97-110. 


\section{Methodology}

The purpose of the research is to describe the main features of the culture of education in Poland and the Republic of Korea, its main indicators, and how it affects the education of students from these countries. The main research question is: How do societal and educational it affect the Asian educational experiences of students from Confucius Heritage Countries (CHC) and Western European students? The sub-questions are: What were the social and cultural contexts that formed Socratic and Confucian philosophies of education? What is the impact of their educational philosophies on Western and Asian education? What are the main features of the culture of education in Poland and South Korea? In what way the culture of education affects learning in Poland and South Korea? How does educational culture affect communication in a classroom setting in the studied countries?

In the qualitative paradigm of empirical research, we want to examine a personal interaction between two cultures: a background culture and experienced culture. Qualitative research does just that - attempts "to make sense of, or to interpret, phenomena in terms of the meanings people bring to them" ${ }^{8}$. The method employed in the study is hermeneutics or interpretation of the literary texts; thus, the study is also cross-cultural. We have considered the chosen opinions on the culture of education and the selected results of empirical research conducted by different authors

8 S. Juszczyk, Badania jakościowe w naukach społecznych. Szkice metodologiczne, Katowice 2013, p. 8. 
on this subject. The cross-cultural study refers to the process of looking at cultural phenomena from the perspective of both cultures in which they occur ${ }^{9}$.

The culture can be shared not only by a group but also individually experienced ${ }^{10}$. The analysis is based on the critical theory, defined as a social theory focusing on power, justice, and interactions between race, class, ideologies, education, and cultural dynamics. Thus, we can better understand them to create justice for all involved ${ }^{11}$. The study provides a better understanding of how Polish and Korean students interact with their education and culture. Their origins are Confucius' and Socrates' philosophies and impacts on the culture of education in these countries. The analysis continues previous studies ${ }^{12}$.

\section{Socratic Education Philosophy}

Socrates (469-399 B.C.), the Greek philosopher, remains one of the most influential figures in the history of Western philosophy. He was interested in ethics, the conduct of life,

9 M.D. Pusch (ed.), Multicultural Education, New York 1979, p. 107.

10 A. Ark, Culture, Confucianism, and Communication: how culture affects international students from China and Taiwan who come to the U.S. to study education, a thesis in Middle State University in the Midwest 2013.

11 J.L. Kincheloe, P. McLaren, Rethinking critical theory and qualitative research, [in:] Handbook of qualitative research, eds. N.K. Denzin, Y.S. Lincoln, 2017, pp. 279-313.

12 S. Juszczyk, Y.D. Kim, Impact of culture on education in Poland and South Korea. A Comparative Analysis, "The New Educational Review" 2017, vol. 48, no. 2, pp. 132-143; idem, Confucian Thought Affecting Education in South-East Asian Countries vs. Socratic Education Philosophy in Western Countries, "Athenaeum. Polish Political Science Studies" 2017, no. 56, pp. 97-110. 
moral truth, or the higher ends in what one must do to be $\operatorname{good}^{13}$. Socrates talked in public - in the marketplace, outside the gymnasium, at parties, or wherever he happened to be. Moreover, he would talk philosophy with virtually anyone - fellow philosophers or sophists, public figures, playwrights, rich people or poor people, adults or children, and even slaves ${ }^{14}$.

Socrates used the question-and-answer technique in his search for true knowledge. The process is described with details by Nel Noddings ${ }^{15}$. The simple questions would be "What is truth?" or "What does it mean to be just?". When the other person answered, Socrates responded with another question that prompted him or her to think more deeply to offer a new answer. Such a strategy, which came to be known as the Socratic Method, has been regarded as perhaps one of the earliest teaching strategies ever described in education history, as writes Darcy Miller ${ }^{16}$. Socratic Method is a dialectic teaching method that "involves dialogue and questioning, emphasizing the exchange of ideas and suppositions that then transform knowledge itself". It became a prototype of the heuristic method, which has played a significant role in the teaching and learning process. Socratic dialogue is all about the person who speaks and discovers the truth about herself.

13 P. Abbs, Socratic Education, ed. A. McClellad, London 1993.

14 H. Wang H., Cultural interpretations of Socratic and Confucian education philosophy, dissertation 2013, pp. 26-27, The University of Louisville Institutional Repository, http://ir.library.louisville.edu/cgi/ viewcontent.cgi?article $=1604 \&$ context=etd [access: 20.05 .2017 ]

15 N. Noddings, Philosophy of Education, Colorado 2007, pp. 3-4.

16 D. Miller, Learning Strategies, Encyclopedia of Educational Psychology, eds. N.J. Salkind, K. Rasmussen, vol. 2, London 2008, p. 963. 
Gary Alan Scott ${ }^{17}$ characterizes the Socratic method of education as the "integrative" model, in which new knowledge is thought to be substituted for, or integrated with old knowledge or belief in such a way that both the content and form of one's knowledge might be said to be fundamentally reformulated, reconstituted, or reconfigured. The incompatibilities and inconsistencies in the various beliefs and opinions must be reconciled, and new ideas can be appropriated or assimilated into the old knowledge.

The Socratic method has been used successfully for a long time, among other things, in school education, during which the teacher asks students a question, giving understandable examples, and then waits for the student's response. The student also asks the teacher questions to see does he or she understand them well. Unfortunately, although they are asked questions, many students do not answer them (these are the so-called hidden questions), which can lead to a misunderstanding of the content discussed in the lesson and a decrease in the teaching process effectiveness ${ }^{18}$.

\section{The Confucian Education Model in CHC Countries}

Kong Qiu, generally known in China by the respectful appellation of Kong-fuzi' Master Kong', lived in 551-479 B.C. Jesuit missionaries Latinized this name to Confucius, and that of his famous follower Mengzi to Mencius, the names by which they are generally known in the West. Confucius

17 G.A. Scott, Plato's Socrates as Educator, New York 2000, p. 41.

18 W. Kojs, J. Gabzdyl, Questions Hidden in Schoolchildren's Responses - Structure and Didactic Functions, "The New Educational Review” 2016, vol. 45, no. 3, pp. 89-101. 
was the first in an age of Chinese philosophers contemporary with the great philosophers of ancient Greece. However, the main focus of Chinese philosophy was government and ethics rather than logic. He was a great thinker and educator and one of the most learned people in China. For Confucius, the primary source is the Analects ${ }^{19}$, compiled by disciples within a generation or two of Confucius' death ${ }^{20}$. However, his ideas are still unfamiliar to many in the West. He is praised in China as a great teacher. Confucius' heritage is central to people's fundamental beliefs in education, including China, Japan, and Korea. As the Golden Rule or a national cult, Confucianism has affected the state's politics, economy, society, culture, and education for many centuries $^{21}$.

W.O. Lee characterizes the concept of education in the Confucian tradition with the help of the following major themes: (a) the significance of education: "The significance of education stands out in the Confucian tradition. Education is perceived as important not only for personal improvement but also for societal development"22; (b) continuous development; (c) educability for all and perfect ability for all; (d) learning effort and willpower.

19 The Analects of Confucius, 1990, http://www.acmuller.net/condao/analects.html [access: 12.03.2017].

20 J. Chen, Confucius as a Teacher, Beijing 1990; R. Tweed, D. Lehman, Learning considered within a cultural context: Confucian and Socratic approaches, "American Psychologist" 2002, vol. 57, no. 2, p. 91.

21 K.K. Hwang, Filial piety and loyalty: Two types of social identification in Confucianism, "Asian Journal of Social Psychology" 1999, vol. 2, pp. 163-183.

22 W.O. Lee, The cultural context for Chinese learners: Conceptions of learning in the Confucian tradition, [in:] The Chinese learner: Cultural, psychological and contextual influences, eds. D.A. Watkins, J.B. Biggs, Hong Kong 1996, pp. 25-41. 
As for the teaching method, Confucius adopted "educating someone according to his natural ability" and "heuristic education" approaches ${ }^{23}$. He claimed that he was "a transmitter, not a maker" ${ }^{\prime 2}$. For him, learning was viewed as a process by which individuals' minds acquire what is out there; education is taken in terms of cultural transmission, service to society, and moral transformation. One can describe its teaching model as "knowledge-transfer", in which knowledge is presumed to transfer from one who has it to one who does not ${ }^{25}$. Gary Alan Scott ${ }^{26}$ writes the "knowledge-transfer" model assumes that learning is defined by increasing the sum of the factual information at one's disposal. So, from this view, new information is merely added to whatever knowledge one previously had, like new data is added to a data bank or an inventory is added to a warehouse.

\section{Confucius' Ideas about Education in Practice}

The specific features of Confucian heritage in education are: learning by induction, the generation of concepts, and the inference of high-level principles through repeated observation, practicing, and memorization of empirical examples. Learners create meaning by generalizing concepts and from

23 The Analects of Confucius, 1990, book VII, chapter XIX, http:// www.acmuller.net/con-dao/analects.html [access: 12.03.2017].

24 Ibidem.

25 H. Wang, Cultural interpretations of Socratic and Confucian education philosophy, dissertation 2013, pp. 26-27, The University of Louisville Institutional Repository, http://ir.library.louisville.edu/cgi/viewcontent.cgi? article $=1604 \&$ context=etd [access: 20.05 .2017 ].

26 G.A. Scott, Plato's Socrates as Educator, New York 2000, p. 40. 
what they already know or what they have observed. Inductive pedagogy is used in this "model" of Asian learning ${ }^{27}$.

Confucian values and norms are mainly centered on examinations. Most Asian students have to memorize their lessons, especially definitions, rules, procedures, facts, concepts, and short reading selections such as poems and very short passages. In some schools, students who failed to memorize their notes are made to stand in class until they can recite whatever was assigned to be memorized. The examination includes fill-in-the-blanks items, defining terms, and enumerating. Teachers find these test items easy to prepare and to check. If they give test items with multiplechoice questions, the choices are not chosen well, leading to too obvious answers or confusing answers ${ }^{28}$. The reflections of Confucianism in contemporary Korean higher education and Confucian leadership are based on two main themes: personal and socio-political order. As writes Jeong-Kyu $\mathrm{Lee}^{29}$, based on the dual Confucian leadership, the characteristic of leadership in Korean higher education is still hierarchically authoritative. In recent years, with having achieved higher stages of economic development in Korea, Confucian values and principles are gradually decreasing, while Western values and assumptions are rapidly increasing.

In Asian schools, the relationship between students and teachers is hierarchical. Students should respect teachers

27 D.A. Watkins, J.B. Biggs (eds.), The Chinese Learner: Cultural, Psychological and Contextual Influences, Hong Kong 1996.

28 Education style: Asian vs Western, http://www.support.acadsoc. com/education-style-asian-vs-western [access: 25.01.2017].

29 J.-K. Lee, Confucian Thought affecting leadership and organizational culture of Korean higher education, "Radical Pedagogy" 2001, vol. 3, no. 3, pp. 1-11, http://radicalpedagiogy.icaap.org/content/issue3-3/5-lee. html [access: 23.01.2017]. 
and avoid disagreeing with them as much as possible. Due to the hierarchical and formal relationship, the thought of talking to teachers about matters outside school makes Asian students cringe. The courses in most Asian education systems are lecture-based, meaning that teachers unilaterally transfer information to students. When the teacher is talking, students make meticulous notes, trying to write down as much as possible. If the teacher asks a question, students shy away from answering them as they are embarrassed by speaking in front of their classmates or afraid of giving the wrong answer ${ }^{30}$. The significant phenomenon observed in many Asian countries is education in the so-called "private academies", in which numerous Asian students enroll after school, where there are teachers who teach the same material taught at school. Especially in Korea, many students have tutors waiting for them at home to review their lessons for the day and to study in advance for the coming lessons at schools. This phenomenon called a "shadow education system" is a big social problem in Korea because numerous Korean students enroll in private academies after school. Some teachers teach the same material as the school. The parents pay for privately provided additional tuition ${ }^{31}$.

The academic success of Confucian Heritage Culture's students has been attributed, at least partially, to the efforts parents put into their children's learning and how much these parents value education. Chi-Chung Lam and coworkers have found that parents in Hong Kong respect and

30 Z. Zhao, Schooling in China, [in:] Going to school in East Asia, eds. G.A. Postiglione, J. Tan, 2007, pp. 65-85; B. Mark, An exploration of speaking-in-class anxiety with Chinese ESL learners, "System" 2011, vol. 39, no. 2, pp. 202-214.

31 M. Bray, Confronting the Shadow Education System: What Government Policies for What Private Tutoring?, Paris 2009. 
trust schoolteachers and are very cooperative with teachers, but they are not ready to take the role of "decision-makers" and would like to be "distant assistants" 32 . This role of parents enhances student achievement, reduces absenteeism and dropout rates, and improves homework habits ${ }^{33}$. According to I.W. Pang, they tend to restrict their involvement in home because that made both parents and teachers feel most comfortable ${ }^{34}$.

\section{Comparison of Culture of Education in Poland and Republic of South Korea}

In Poland dominates an individualistic culture, in which people look after themselves and their immediate family. Values are in persons, and there is more explicit verbal communication. Poland is under the influence of a monotheistic religious system, mainly the Christian. People in our country believe that there is an absolute and indivisible truth. South Korea belongs to high scoring countries practicing Buddhism, in which people believe that truth depends on time, context, and situation. A very characteristic social feature in Korea is how parents view formal education and extracurricular activities, their involvement in learning ac-

32 Ch.-Ch. Lam, E.S. Ho, N-Y. Wong, Parents' beliefs and practices in education in Confucian Heritage Cultures: The Hong Kong case, "Journal of Southeast Asian Education" 2002, vol. 3, no. 1, pp. 99-114.

33 E.S. Ho, The nature and impact of social capital in three Asian educational systems: Singapore, Korea, and Hong Kong, "International Journal of Educational Policy, Research and Practice" 2000, vol. I, no. 2, pp. 171-189.

34 I.W. Pang, Functions of the parents-teacher association (PTA): A Hong Kong perspective, "Educational Journal" 1997, vol. 25, no. 1, pp. 81-106 . 
tivities at home (improving homework habits), and their willingness to be involved in extracurricular activities in school (in enhancing student achievement, reducing absenteeism, and dropout rates) ${ }^{35}$.

However, in both studied countries, we can find high power-distance cultures, in which everybody has a rightful place in society. It means that older people are respected, and status is important. It causes that between teachers and students is a clear hierarchy, and students always show respect to teachers and avoid disagreeing with them as much as possible. These differences and similarities impact the leadership and organizational culture of the education systems in Poland and the Korean Republic ${ }^{36}$.

However, in Poland dominates learner-centered education $^{37}$, while in Korea, teacher-centered education. In both systems, the courses are lecture-based, meaning that teachers unilaterally transfer information to students. Students are made to memorize their lessons in schools of both countries, especially definitions, rules, procedures, facts, and concepts. The reason for such a situation are examinations (with the use of tests) after finishing different levels of

35 E.S. Ho, The nature and impact of social capital in three Asian educational systems: Singapore, Korea, and Hong Kong, "International Journal of Educational Policy, Research and Practice" 2000, vol. I, no. 2, pp. 171-189; Ch.-Ch. Lam, E.S. Ho, N.-Y. Wong, Parents' beliefs and practices in education in Confucian Heritage Cultures: The Hong Kong case, "Journal of Southeast Asian Education" 2002, vol. 3, no. 1, pp. 99-114.

36 G. Hofstede, J. Hofstede, Cultures and organization-software of the minds, New York 2005.

37 S. Juszczyk, Education system in Poland, [in:] European Education (and Training) Systems, ed. S. Juszczyk, Toruń 2014, pp. 267-294; S. Juszczyk, K. Yongdeog, Social roles and competences of the teacher in a virtual classroom in Poland and Korea, "The New Educational Review" 2015, vol. 42, no. 4, pp. 153-164. 
education. If the students obtain a test with multiple-choice questions, the choices are not correct, leading to too obvious or confusing answers. However, in both countries, students and parents credit considerable importance to scores, school ranking, and test results.

Taylor points out that in addition to learning style differences between cultural groups, variations exist also in the rules for oral (verbal) communication ${ }^{38}$. Teachers and students will naturally follow the assumptions and rules from their respective cultures. Any analysis of interpersonal communication in the classroom is incomplete without considering non-verbal aspects of communication. Understanding communication derives from the interaction of the verbal and non-verbal activities with each other and the context in which they occur ${ }^{39}$. Minimum communicative competence includes the meaning of a smile, eye contact, conversational distance, and actual touching; in Asian cultures are important the following aspects: time, space, and context ${ }^{40}$. Teaching in South Korea is traditionally dominated by a teacher-centered, book-centered method and an emphasis on rote memory ${ }^{41}$. These traditional teaching approaches have resulted in many common learning styles. According to some Western academics, the CHC students are modest

38 O.L. Taylor, Cross-cultural communication: An essential dimension of effective education, Washington D.C. 1990.

39 E.T. Hall, Hidden Differences: Studies in International Communication, Hamburg 1985.

40 R.F. Littrell, Learning styles of students in and from Confucian cultures, 2006, http://www.reaserchgate.net/publication/228347305 [access: 25.07.2017].

41 N.F. Liu, W. Littlewood, Why do many students appear reluctant to participate in classroom learning discourse?, "System" 1997, vol. 25, no. 3 , pp. 371-384. 
and diligent ${ }^{42}$. However, at the same time, some of their typical learning characteristics are described negatively, such as rote, silent, and passive learning styles ${ }^{43}$.

Jin $\mathrm{Li}^{44}$ grew up thoroughly Chinese even though she has lived in the USA for many years, thus in her book Cultural Foundations of Learning: East and West, in such manner she summarized the Confucian learning tradition, which holds to the following (p. 14): (a) learning is the most important thing in life; it is life's purpose; (b) learning enables one to become a better, not just more intelligent person; (c) learning is a life-long process; (d) the kind of knowledge that sets one person apart from another does not come to one automatically. One must seek it. Seeking knowledge requires diligence, resolve, enduring hardships, steadfastness, concentration, and humility. In contrast, students from Western cultures have a different approach to learning which follows the key themes (p. 15): (a) human curiosity about the external world is the inspiration for knowledge; (b) a relentless spirit of inquiry into the universe will lead to knowledge; (c) mind in the highest human faculty that enables this inquiry; (d) reason (not heart) is the process by which we know the world; (e) the individual is the sole entity for inquiry, discovery and ultimate triumph.

42 C.C. Park, Learning style preferences of Southeast Asian students, "Urban Education" 2000, vol. 35, pp. 245-268.

43 H.H.W. Sit, Characteristics of Chinese Students' Learning Styles, "Int. Proceed. of Economic Development and Research" 2013, no. 62, pp. 36-39. 2012.

44 J. Li, Cultural Foundations of Learning: East and West, Cambridge 


\section{Conclusions}

Analyzing similarities, differences, difficulties, and positive features of the education systems in Poland and South Korea, we can wonder how Korea can rise so quickly and continue to have one of the most successful education outcomes in the world. Polish education rises from year to year, but our development is not as strong as in Korea. In both countries after the second world war (Poland) and after the Japanese occupation (Korea), the changes made in their education systems were highly focused on the country's productivity through access to education. By increasing the literacy rate, the Polish and Korean populations are more equipped to make better decisions about societal changes. By increasing accessibility to education, our societies would have knowledge of the various fields that support the countries.

In conclusions, one can say that the culture of education in both studied countries has different values of the indicators that characterize it: the education system, the upbringing process, the educational process, the subjectivity of the pupil, the methods of teaching, the teacher-student relationship, the norms and values adopted both in education and in the family home, the competences of teachers and opportunities for their improvement, the economic status of teachers and their social prestige, the structure and equipment of schools and universities and their funding, as well as the organizational culture of the school or university. However, these differences become blurred over time. The education in South Korea focuses, similar as in Poland, on 
"critical thinking skills", on "problem-solving", on "creativity", which are seen to be readily compatible with apparently rote styles of learning. Such shifts might be understood as reflecting the influence of "Western" approaches to learning or as the results of economic developments in many Asian economies ${ }^{45}$.

\section{Bibliography}

Abbs P., Socratic Education, ed. A. McClellad, London 1993. Ark A., Culture, Confucianism, and Communication: how culture affects international students from China and Taiwan who come to the U.S. to study education, a thesis in Middle State University in the Midwest, 2013.

Bray M., Confronting the Shadow Education System: What Government Policies for What Private Tutoring?, Paris 2009.

Bruner J., Culture of Education, "Canadian Journal of Education" 2000, vol. 25, no. 3.

Chen J., Confucius as a Teacher, Beijing 1990.

Tweed R., Lehman D., Learning considered within a cultural context: Confucian and Socratic approaches, "American Psychologist" 2002, vol. 57, no. 2.

Colloques internationaux, Colloque: Léducation en Asie en 2014: Quels enjeux mondiaux?.

Durkin K., The adaptation of East Asian masters students

45 M. Mason, Culture and educational outcomes in "Confucian heritage" societies in Asia, 2014, http://ries.revues.org/3812; Colloques internationaux, Colloque: Léducation en Asie en 2014: Quels enjeux mondiaux?; K. Durkin, The adaptation of East Asian masters students to western norms of critical thinking and argumentation in the $U K$, "Intercultural Education" 2008, vol. 19, no. 1, pp. 15-27. 
to western norms of critical thinking and argumentation in the UK, "Intercultural Education" 2008, vol. 19, no. 1. Education style: Asian vs. Western, http://www.support. acadsoc.com/education-style-asian-vs-western.

Hall E.T., Hidden Differences: Studies in International Communication, Hamburg 1985.

Hofstede G., Hofstede J., Cultures and organization-software of the minds, New York 2005.

Hwang K.K., Filial piety and loyalty: Two types of social identification in Confucianism, "Asian Journal of Social Psychology" 1999, vol. 2.

Ho E.S., The nature and impact of social capital in three Asian educational systems: Singapore, Korea, and Hong Kong, "International Journal of Educational Policy, Research and Practice” 2000, vol. I, no. 2.

Juszczyk S., Badania jakościowe w naukach społecznych. Szkice metodologiczne, Katowice 2013.

Juszczyk S., Education system in Poland, [in:] European Education (and Training) Systems, ed. S. Juszczyk, Toruń 2014.

Juszczyk S., Kultura w edukacji. Implikacje społeczne, aksjologiczne i poznawcze, Toruń 2020.

Juszczyk S., Yongdeog K., Social roles and competences of the teacher in a virtual classroom in Poland and Korea, "The New Educational Review" 2015, vol. 42, no. 4.

Juszczyk S., Kim Y.D., Confucian Thought Affecting Education in South-East Asian Countries vs. Socratic Education Philosophy in Western Countries, "Athenaeum. Polish Political Science Studies" 2017, no. 56.

Juszczyk S., Kim Y.D., Impact of culture on education in Poland and South Korea. A Comparative Analysis, "The New Educational Review" 2017, vol. 48, no. 2. 
Kincheloe J.L., McLaren P., Rethinking critical theory and qualitative research, [in:] Handbook of qualitative research, eds. N.K. Denzin, Y.S. Lincoln, USA 2000.

Kojs W., Gabzdyl J., Questions Hidden in Schoolchildren's Responses - Structure and Didactic Functions, "The New Educational Review" 2016, vol. 45, no. 3.

Lam Ch-Ch., Ho E.S., Wong N-Y., Parents' beliefs and practices in education in Confucian Heritage Cultures: The Hong Kong case, "Journal of Southeast Asian Education" 2002, vol. 3, no. 1 .

Lee W.O., The cultural context for Chinese learners: Conceptions of learning in the Confucian tradition, [in:] The Chinese learner: Cultural, psychological and contextual influences, eds. D.A. Watkins, J.B. Biggs, Hong Kong 1996. Lee J-K., Confucian Thought affecting leadership and organizational culture of Korean higher education, "Radical Pedagogy" 2011, vol. 3, no. 3, pp. 1-11, http://radicalpedagiogy.icaap.org/content/issue3-3/5-lee.html.

Li J., Cultural Foundations of Learning: East and West, Cambridge 2012.

Littrell R.F., Learning styles of students in and from Confucian cultures, 2006, http://www.reaserchgate.net/publication/228347305 - 25.07.2017.

Liu N.F., Littlewood W., Why do many students appear reluctant to participate in classroom learning discourse?, "System" 1997, vol. 25, no. 3.

Maciaszkowa J., Kultura pedagogiczna rodziców, [in:] Pedagogika opiekuńcza. Materiaty z Krajowej Konferencji Komitetu Nauk Pedagogicznych PAN, Warsaw 1997.

Mark B., An exploration of speaking-in-class anxiety with Chinese ESL learners, "System" 2011, vol. 39, no. 2.

Mason M., Culture and educational outcomes in "Confu- 
cian heritage" societies in Asia, 2014, http://ries.revues. org/3812.

Miller D., Learning Strategies, [in:] Encyclopedia of Educational Psychology, eds. N.J. Salkind, K. Rasmussen, vol. 2, London 2008.

Noddings N., Philosophy of Education, Colorado 2007.

Pang I.W., Functions of the parents-teacher association (PTA): A Hong Kong perspective, "Educational Journal" 1997, vol. 25 , no. 1 .

Park C.C., Learning style preferences of Southeast Asian students, "Urban Education" 2000, vol. 35.

Pusch M.D. (ed.), Multicultural Education, New York 1979.

Scott G.A., Plato's Socrates as Educator, New York 2000.

Sit H.H.W., Characteristics of Chinese Students' Learning

Styles, "Int. Proceed. Of Economic Development and Research" 2013, no. 62.

Szczepański J., Co rozumiemy przez kulturę pedagogiczną?, „Rodzina i Szkoła” 1979, no. 11.

Taylor O.L., Cross-cultural communication: An essential dimension of effective education, Washington D.C. 1990.

The Analects of Confucius, 1990, http://www.acmuller.net/ con-dao/analects.html.

Wang H., Cultural interpretations of Socratic and Confucian education philosophy, dissertation 2013, pp. 26-27, The University of Louisville Institutional Repository, http:// ir.library.louisville.edu/cgi/viewcontent.cgi ?article= $1604 \&$ context $=$ etd.

Watkins D.A., Biggs J.B. (eds.), The Chinese Learner: Cultural, Psychological and Contextual Influences, Hong Kong 1996.

Winiarski M., Rodzina - szkoła - środowisko lokalne. Problemy edukacji środowiskowej, Warsaw 2000. 
Zhao Z., Schooling in China, [in:] Going to school in East Asia, eds. G.A. Postiglione, J. Tan, 2007.

\begin{abstract}
Socrates and Confucius constitute roots of western and eastern civilizations, respectively, and represent very different cultural values and educational traditions. Different cultural and social factors in ancient Greece and China led to differences in Socratic and Confucian approaches to learning. Their educational philosophies have been discussed based on the culture of education, education aim and content, the teaching process, and the nature of contemporary education, which are the indicators of the culture of education in Poland and South Korea. The method used in the described study is hermeneutics or interpretation of the literary (here scientific) texts; thus, the study is cross-cultural and concerns the features of contemporary education in both countries.
\end{abstract}

Keywords: culture, education, Socratic philosophy, Confucian philosophy, Poland, South Korea

\begin{abstract}
Abstrakt
Sokrates i Konfucjusz byli twórcami podstaw zachodnich i wschodnich cywilizacji oraz reprezentantami odmiennych wartości kulturowych i tradycji nauczania. Różne czynniki społeczne i kulturowe obecne w starożytnych Chinach i Grecji doprowadziły do powstania sokratejskiej i konfucjańskiej perspektywy edukacji. Filozofie obu klasyków wciąż są rozważane w kontekście kultury nauczania, celu i treści edukacji, procesu przekazywania wiedzy i natury edukacji, które są fundamentalnymi elementami kultury edukacji w Polsce i Korei Południowej. Do analizy tego zagadnienia posłużono się metodą hermeneutyczną oraz interpretacji literackiej. Dzięki temu zabiegowi badanie ma charakter międzykulturowy i dotyczy najważniejszych cech współczesnej edukacji w obu państwach.
\end{abstract}

Słowa kluczowe: kultura, edukacja, filozofia sokratejska, filozofia konfucjańska, Polska, Korea Południowa 


\section{Katarzyna Chałubińska-Jentkiewicz \\ War Studies University \\ ORCID ID: https://orcid.org/0000-0003-0188-5704}

\section{Internet Access Rights in Central Asian Countries}

\section{Introduction}

In the modern network society, two trends collide. Namely, media activities globalization - understood as programs and on-demand audio-visual services delivered for informational, entertainment, educational, and commercial purposes through telecommunications networks, for which the providers are responsible - with the individual countries' struggles aimed at the legal and organizational arrangement of the contemporary network society. The latter often contradicts the cult of technology and market logic associated with globalization.

Thus, the scope of state regulation may conflict with the values of the information society and the democratic state of law by creating limitations on the right to obtain information and making it available. Restrictions on the freedom of speech and access to information may arise in place of activities that should create a new cultural policy that would encourage the emergence of a new informationism policy based on contemporary values and problems of the network society. It applies to attempts to adapt regulatory measures typical of traditional public media, which are anachronistic 
under the conditions of digitization, at least in some areas, to the new conditions and level of technological advancement. Due to the specific nature of the ICT network and the multifunctionality of increasingly cheaper and improved mobile devices (Moore's law), this type of adaptation can restrict freedom of speech and the right to communicate. Meanwhile, communication processes are a characteristic feature of social development. The digital processes have created the new society, i.e., the information society and the so-called digital democracy, which is at the same time a response to the challenges of living in the digital reality.

The main focus of activities in a digital democracy is public participation in the exercise of public authority through the possibility of a broad debate in public forums like never before. The tasks of digital democracy and their execution in virtual reality remain open. They need to be constantly strengthened, as information and access to it become a special kind of public goods and, at the same time, an individual's inherent right. The condition for the preservation and development of this good is the universal and innovative management of the content disseminated through new media and the guarantee of the right of access to the ICT network, understood as the right to access the Internet, which constitutes a human right.

According to a BBC World Service survey of 27000 adults in 26 countries: "almost four out of five people worldwide believe that access to the Internet is a fundamental right". In this context, it is important to recall one of the most important principles reported at the World Summit on the Information Society (Geneva 2003 - Tunisia 2005). The participants of this conference declared their common desire and commitment to build a people-centered, inclu- 
sive and development-oriented Information Society, where everyone can create, access, utilize and share information and knowledge, enabling individuals, communities and peoples to achieve their full potential in promoting their sustainable development and improving their quality of life, premised on the purposes and principles of the Charter of the United Nations and respecting fully and upholding the Universal Declaration of Human Rights. On the one hand, some countries and international organizations consider Internet access a fundamental and universal human right. On the other hand, many governments consider tighter control over the content and the right to block technical means of content overflow.

\section{Network Neutrality}

An important element of regulation and rationing of new media is network neutrality, which means the principle of the Internet access service, according to which Internet traffic of the same type is treated equally, i.e., without discrimination, restrictions, slowdowns, or disruptions, regardless of the sender, recipient, content, device, service or application. Endusers have the right to access and distribute information and content of their choice, and to use and deliver applications and services of their choice, as well as to use terminal equipment of their choice as a part of the Internet access service. Blocking, slowing down, or degrading traffic transmitted on the Internet is prohibited unless it serves specifically to:

(a) enforce the court decision;

(b) ensure the integrity and security of networks or services provided over networks, terminal equipment of 
end-users, provided that equivalent types of traffic are treated equally;

(c) prevent or minimize the effects of temporary and exceptional network congestion, provided that equivalent types of traffic are treated equally.

In Poland's proposal for net neutrality, the text of the draft regulation of the European Parliament and the Council entitled Connected Continent defines "Internet access services" by referring to the best effort model with a clear emphasis on the principle of net neutrality. Regulation (EU) 2015/2120 of the European Parliament and of the Council of 25 November 2015 laying down measures on access to the open Internet and amending Directive 2002/22/EC on universal service and users' rights relating to electronic communications networks and services and Regulation (EU) No 531/2012 on roaming on public mobile communications networks within the Union introduced the concept of "Internet access service", which means an electronic communications service available to the public that provides access to the Internet and thereby connects to virtually all Internet network terminations regardless of the network technology and terminal equipment used. Article 3 of Regulation (EU) 2015/2120 introduces the principle of access to and distribution of information and content through an ICT network ${ }^{1}$. This right also includes the use and sharing of selected applications and services and the use of selected

1 Regulation (EU) 2015/2120 of the European Parliament and of the Council of 25 November 2015 laying down measures concerning open internet access and amending Directive 2002/22/EC on universal service and users' rights relating to electronic communications networks and services and Regulation (EU) No. 531/2012 on roaming on public mobile communications networks within the Union (Text with EEA relevance), OJ L 310, 26.11.2015, pp. 1-18. 
end devices, regardless of the location of the end-user or service provider or the location, origin, or destination of the information, content, or service.

According to this Regulation, "In order to exercise their rights to access and distribute information and content and to use and provide applications and services of their choice, endusers should be free to agree with providers of internet access services on tariffs for specific data volumes and speeds of the internet access service. Such agreements and any commercial practices of providers of internet access services should not limit the exercise of those rights and thus circumvent provisions of this Regulation safeguarding open internet access. National regulatory and other competent authorities should be empowered to intervene against agreements or commercial practices which, because of their scale, lead to situations where end-users choice is materially reduced in practice".

The objective of reasonable traffic management is to contribute to efficient use of network resources and optimize overall transmission quality responding to the objectively different technical quality of service requirements of specific traffic categories, and thus of the content, applications, and services transmitted. Reasonable traffic management measures applied by providers of internet access services should be transparent, non-discriminatory, proportionate, and should not be based on commercial considerations. The requirement for traffic management measures to be non-discriminatory does not preclude providers of internet access services from implementing to optimize the overall transmission quality, traffic management measures that differentiate between objectively different categories of traffic. To optimize overall quality and user experience, any such differentiation should be permitted based on the 
objectively different technical quality of service requirements (for example, in terms of latency, jitter, packet loss, and bandwidth) of specific traffic categories, not on commercial considerations.

It should be emphasized that not every country adopts a policy of openness of the ICT network, which, apart from the Middle East, is particularly visible in Central Asia. According to an estimate from the Privatizing Censorship report, Eroding Privacy, the number of countries where imprisonment is provided for online publications has increased by half since 2013. Since June 2015, the police in 38 countries worldwide have conducted arrests of citizens in connection with their activity in social media.

\section{The Access to the Internet in European Union Countries}

Like the traditional media, the Internet can be used for illegal or at least socially reprehensible activities. Even more so, the strength and speed of the network message multiply the threats traditionally associated with the abuse of freedom of speech, the freedom of political parties, or the freedom to conduct business. In this context, members of the information society and participants in digital democracy are at risk of conscious manipulation, also of political and social nature, often with the use of their data collected through big-data processes. According to the studies of the processes in political life and due to the politicization of law-making, also within the legislative process, the problem of the quality of the network even affects mature democracies. The manipulation of content on the Internet, including the deliberate dissemination of the so-called fake news, may lead to 
undermining the credibility of politicians, lawyers, and even the world of science (especially in terms of so-called climate change denial), thus undermining public order and systemic stability and vital social interests. Therefore, the need to revise the existing principles of responsibility for the word, including penalizing the dissemination of false and dangerous information and counteracting media propaganda, seems to be one of the key problems faced by the contemporary legislator. The balance between freedom of speech and quality of the network highlights the role of soft law in regulating the processes of the network society.

As a result of the evolution of new technologies, changes in legislation must be made. This process takes place in a period of technological development, including the development of digital technology, with a simultaneous increase in consumer needs, also resulting from globalization. The development of new technologies, as well as the related processes of social change, require a new regulatory approach, as well as a redefinition of public interest objectives and state responsibilities in the process of regulating those areas that touch upon key issues related to the functioning of an individual: citizen, market and state. The convergence processes in the existing regulatory areas understood in different ways contribute to a particular type of conflict in findings on the scope and level of new regulations. Speaking about the changes brought about by new technologies, it should be remembered that this phenomenon requires an interdisciplinary approach, combining knowledge and methodology appropriate not only for law but also for economics, sociology, technology, media, political science, psychology, cultural studies, and security sciences. Given the interdisciplinary approach, it is necessary to set stan- 
dards (previously principles and values) applicable to the real world. Freedom in the Internet also requires safety and security. Therefore, the regulatory policy seems to be necessary.

However, as the state moves away from existing models of public governance towards a system corresponding to a post-modern network society, it should gradually reduce the scope for exercising its management function in favor of strategy formulation and mechanisms for development, standardization, and mediation. The revolutionary changes, according to the authors of the report, concern, in particular, the way the state is managed (for example, in the area of e-Government), primarily because "the existing methods of governance and state management will simply not be effective in a society where information has become the main product". Modern technologies have become the cause of administrative convergence, i.e., a process involving the creation of new, common administrative solutions in place of the traditional, organizationally conditioned separations of state administration bodies. Such areas are often defined at the European Union level.

Moreover, in today's state, it is becoming increasingly necessary to take a strategic view which, in conditions of hitherto unknown threats related to the development of the network society and the knowledge-based economy, enables the country to develop properly. An important element of this function is the definition of prospects, which requires a comprehensive analysis of complex local and global conditions, economic, social, and political needs and interests, and the ability to meet individual needs. Diagnosis and strategy allow for the establishment of appropriate regulatory policy. Regulatory policy is closely linked to manage- 
ment. The sphere of network development management, in turn, is characterized by a focus on the future functioning of the state and society in place of traditional ex ante or $e x$ post rationing restrictions.

For this reason, the sphere of governance should be one of the main objectives of public policy in the area of new technologies. As part of the planning process, the function of public authority is to set out actions aimed at achieving specific objectives and redefine these objectives, considering the requirements of the development of modern. All elements of modern technology, which can include software, services, databases, or ICT devices, are characterized by the same features, i.e., 1) speed (rapid market changes in the area of services, the area of technical innovation, especially in the context of network development, the need for scientific research in the area of data storage, etc.); 2) globalization (modern technologies enable the global exchange of services in real-time); 3) entrepreneurship (joint research for innovation, public-private partnership); 4) social participation (creation of innovative solutions by network users, development of social media, crowdsourcing, being an exchange of ideas, entailing the development of technology and innovation); 5) convergence (combining many areas of human activity). These features justify the changes and transformations in creating a new management system with the use of legal instruments. The legal system in this area must follow technological change and the accompanying social changes. Given the pace of technological and, consequently, economic change, this system must be flexible, and the legal solutions should include universal standards that allow for their application in different conditions and situations. 
The right of access to the Internet has not been fully developed in national or European literature. Therefore, the research carried out under this project will attempt to provide a comprehensive view of the issue, together with an indication of specific systemic solutions based on regulations existing in the legal systems of other countries, such as the United Kingdom or France.

The project's main objective will be to answer the question about the need and appropriate form to recognize the "right to the Internet" in the catalog of fundamental rights ${ }^{2}$ . To this end, the need to recognize access to the Internet as a separate category of protected goods must first be consid$\operatorname{ered}^{3}$. This question cannot be answered without defining precisely where the border between cyberspace, the Internet, and the services is drawn.

Only after an initial conceptualization of this "right to the Internet" will it be possible to make it more concrete regarding its legal nature and its relationship with other public subjective rights. It will then be necessary to refer to the legitimacy of introducing the "right to the Internet" as a category of fundamental rights ${ }^{4}$. Against this background, the comparative experience of the absorption of other modern human rights in individual regions and cultures of the world

2 B. Skepys, Is There a Human Right to the Internet?, "Journal of Politics and Law" 2012, no. 5, pp. 15-29.

3 A separate problem is whether it should take the form of "law" or "freedom". This issue is discussed in: M. Siemankiewicz, Czy prawo dostepu do Internetu jest prawem człowieka? (Is the right of access to the Internet a human right?, "Prawo Mediów Elektronicznych" 2016, no. 1, p. 73.

4 Ł. Szoszkiewicz, Internet Access as a New Human Right? State of the Art on the Threshold of 2020, "Adam Mickiewicz University Law Review" 2018, no. 8, pp. 49-63. 
will undoubtedly be exciting. One example is protecting personal data, which is a fundamental rights category both within the EU and in the individual Member States, while not having such status in many of the EU's most important trading partners ${ }^{5}$. A separate problem is also the clarification of the relationship between the "right to the Internet" (and the "right to a good Internet") and other public subjective rights - such as the right to information, freedom of expression, and the right to privacy ${ }^{6}$. Only by recognizing that the "right to the Internet" is per se an independent object of protection that the search for legal means to ensure it is effective would be justified.

The above considerations should also apply to both national and EU legal models. The long-awaited reform of the EU telecoms market framework will come into force in $2020^{7}$. At the same time, work on the e-privacy regulation is coming to an end ${ }^{8}$. The proposed legal model of the pro-

5 M. Rojszczak, Prawne dylematy regulacji cyberprzestrzeni: konflikt pomiędzy bezpieczeństwem narodowym a prawem do prywatności z perspektywy prawodawstwa UE $i$ USA (The legal dilemmas of regulating cyberspace: the conflict between national security and the right to privacy from the perspective of EU and US legislation), "TEKA of Political Science and International Relations" 2018, no. 13, pp. 155-173.

6 P. de Hert, D. Kloza, Internet (access) as a new fundamental right. Inflating the current rights framework?, "European Journal of Law and Technology" 2020, no. 3.

7 Proposal for the Regulation of the European Parliament and of the Council on respect for private life and protection of personal data in electronic communications and repealing Directive 2002/58/EC (Regulation on privacy and electronic communications), CELEX 52017PC0010. G. Buttarelli, The Commission Proposal for Regulation on E-privacy: Why Do We Need Regulation Dedicated to E-privacy in the European Union, "European Data Protection Law Review" 2017, no. 3, pp. 155-159; D. Naranjo, E-privacy Regulation: Good Intentions But Lot of Work To Do, "European Data Protection Law Review" 2017, no. 3, pp. 152-154.

8 Directive 2018/1972 of the European Parliament and of the Council 
tection of the "right to the Internet" must account not only for these changes but also for the specific nature of the EU sectoral regulations - especially those relating to the electronic media market, consumer protection, protection of competition (including in terms of technological neutrality), but also those relating to combating digital exclusion and, in a broader sense, the functioning of e-government.

Finally, the concept of the "right to the Internet" makes it possible to clarify it vertically, i.e., in the citizen-state relationship, defining the scope of the state's obligations towards the entitled person. It is one thing for an individual to have the right to access the Internet without interference from third parties, and another for the state to provide such access ${ }^{9}$.

The "right to the Internet" concept will also be supported by a comparative analysis of existing and draft national legislation providing for guarantees in terms of broadband Internet access. The current technological changes - especially those related to introducing the so-called 5G network - make it possible to introduce genuinely "universal access to the Internet" and thus seem to approximate the possibility of implementing the law presented in the form under discussion. At the same time, however, $5 \mathrm{G}$ is a specific technology covered by patent protection. This circumstance creates an area of research that concerns the possibility of reconciling the inevitable widespread use of a particular technology

(EU) 2018/1972 of 11 December 2018 establishing a European code of electronic communications, OJ L of 2018 L 321/36.

9 Compare with considerations set out in: J. Rzucidło, Prawo dostępu do Internetu jako podstawowe prawo człowieka. czesść I (The right to access the Internet as a fundamental human right. Part I), "Prawo Mediów Elektronicznych" 2010, pp. 38-46. 
with ensuring its adequate availability (including financial) and respect for patent rights. The ongoing legal disputes between key technology companies on various elements of the $5 \mathrm{G}$ technology indicate that this problem may appear to be one of the most serious to be resolved on the way to the actual exercising of the right to a universal Internet.

\section{The Access to the Internet in Central Asia Countries}

Based on the Freedom on the net 2015 and 2016 reports, the assessment of digital markets clearly defines the relationship between public authorities and digital media, especially on such a sensitive issue as the regulation of electronic media content, including online media services. The issue of infrastructure regulation and the use of instruments typical for preventive censorship in terms of content is important primarily due to the constant change in the position and roles of market users in the global sphere. Gradual technological developments contributed to the growth of the importance of entities operating the infrastructure at the expense of content providers. For that reason, the regulation of the digital world will take place using the technical level of network access. The examples of selected countries support the thesis that more or less offensive regulation provided by public authorities in the network area is a way of meeting the authorities' needs, even in areas traditionally conceived as free and deprived of state regulation. It is particularly visible in the report Freedom on the net 2020. 


\section{Kazakhstan $^{10}$}

The government has solidified its grip on the information and communication technology (ICT) sector through substantial investments, including direct subsidies to the staterun monopoly Kazakhtelecom. During the coverage period, the government disrupted internet connections during political protests staged by the opposition, riots, and other emergencies. Most people access the Internet from their mobile devices at home, work, and in various public places in cities where high-speed Internet often is available free of charge via Wi-Fi hotspots at cafés and libraries.

Access to various social media platforms and messaging apps, including several Google services like Gmail and YouTube, was also temporarily restricted ${ }^{11}$. Some speculated

10 Internet access has increased significantly over the past decade. According to the most recent official data, $84.2 \%$ of the population used the internet in 2019, a 2.9\% increase over 2018. In February 2019, the state statistical agency reported a $5.5 \%$ decline in the number of fixedline internet subscriptions relative to 2018, but by May 2020 this figure had rebounded $3.7 \%$. This trend, along with the continued increase in overall internet penetration, is a sign that more people are connecting to the internet via mobile devices. Of the 24.5 million active mobile subscriptions in Kazakhstan as of May 2020 - accounting for a 131.5\% mobile penetration rate -14.7 million are used to access the internet. The government's Digital Kazakhstan program has already met its goal of increasing the internet penetration rate to $82.3 \%$ by 2022 . The country's mobile networks continue to expand, but $3 \mathrm{G}$ services are available to only $88 \%$ of the population, and $4 \mathrm{G}$ services to just $75 \%$, according to the Economist Intelligence Unit's 2020 Inclusive Internet Index. Several mobile service providers piloted fifth-generation (5G) services during the coverage period.

11 В Казахстане ограничен доступ к сервисам Google [Google services suspended in Kazakhstan, Vlast.kz, February 16, 2020, https:// vlast.kz/novosti/37259-v-kazahstane-ogranicen-dostup-k-servisam. 
that the restrictions were an attempt to suppress discussion of the late Aisultan Rakhat, a grandson of former president Nazarbayev. He had announced that he was seeking asylum in the United Kingdom ${ }^{12}$. Compared with print and broadcast media, the online media landscape in Kazakhstan is subject to less overt forms of restrictions on the free flow of information, such as pro-government propaganda and pressure to self-censor.

The constitution guarantees freedom of expression, but this right is qualified by other laws and severely restricted in practice by prohibitions on defamation, publication of false information, and other speech-related offenses. Although internet resources are deemed mass media outlets, bloggers do not enjoy the same rights as journalists, and even formally employed journalists face numerous restrictions on their work. In February 2019, for example, the Ministry of Information and Communication said it would further restrict journalists' already limited access to events at state bodies $^{13}$. Nevertheless, the government's plan for developing Kazakhstan's information sphere, adopted in April 2020, envisions raising the profile of bloggers, including by according them the right to be accredited by various government institutions and accorded the same protections traditional journalists enjoy in some circumstances ${ }^{14}$.

12 Kazakh leader's grandson says he is seeking asylum in Britain, Reuters, February 13, 2020, https://www.reuters.com/article/us-kazakhstan-nazarbayev-grandson/kazak.

13 Большая часть журналистов не сможет получить аккредитацию: юрист комментирует приказ министра Абаева [Most journalists won't get accreditation, Current Time TV, February 14, 2019, https://www.currenttime.tv/a/29770437.html.

14 https://rsf.org/en/news/kazakh-journalists-harassed-overcovid-19-reporting. 
During the COVID-19 pandemic, President Tokayev called on the Ministry of Information and Social Development, the Prosecutor General's Office, and other state bodies to "pay close attention to the dissemination of rumors and provocative reports" 15 . The pandemic did generate a wave of misinformation ${ }^{16}$, as local social media influencers spread conspiracy theories about COVID-19. The government has extensive authority to block online content. Many people in Kazakhstan use online resources such as messaging apps to share news - notably, Telegram - which were periodically blocked during the coverage period.

Users who wish to circumvent censorship tend to use virtual private networks (VPNs), but many anonymizing tools have themselves been blocked, and other tools frequently experience service problems.

Access to many social media platforms and an array of other internet resources was interrupted by introducing the national security certificate for several weeks during the summer of 2019. Some, but not all, users attempting to connect to social media platforms like Facebook, OK, Twitter, and VKontakte (VK) and websites such as Mail.ru and YouTube were denied access unless they installed the certificate.

15 K. Akayeva, Fake News on the Coronavirus Pandemic: What Do Central Asians Believe in?, Central Asian Bureau for Analytical Reporting, April 3, 2020, https://cabar.asia/en/fake-news-on-the-coronaviruspandemic-what-do-cen...

16 https://www.codastory.com/disinformation/information-war/ kazakhstan-cel. 


\section{Kyrgyzstan $^{17}$}

The government periodically attempts to increase its control over the Internet. Using security or economic issues as pretexts, officials or members of parliament sometimes call for the centralization of the country's internet infrastructure. One of the latest initiatives was an April $2019 \mathrm{draft}$ regulation that would oblige ISPs to install special equipment for monitoring internet traffic, ostensibly to enforce tax laws.

The authorities continued to engage in disproportionate and arbitrary blocking of online content, largely reflecting official concerns about extremism. The government and the judiciary's broad application of anti-extremism laws have impacted various websites hosting user-generated content. While popular social media platforms are freely accessible, the authorities are examining methods for censoring individual pages on these platforms.

17 Access to the internet continues to expand, with the overall penetration rate reaching $88.3 \%$ in 2019 , according to State Communication Agency (SCA) statistics. As of December 2019, there were 5.7 million internet users out of a population of 6.2 million: almost $15 \%$ more than in 2018. However, the reliability of the SCA's data on internet penetration rates has been questioned by some analysts. The number of internet users identified by the SCA is based on data from service providers. Kyrgyzstan's 2019 mobile penetration rate, estimated at $162.5 \%$ by the SCA, was significantly higher than its overall internet penetration rate. Third-generation (3G) services are available to much of the country. Fourth-generation (4G) services continued to expand during the coverage period, with one operator (Nur Telecom) claiming in January 2020 that its $4 \mathrm{G}$ network reached $97 \%$ of the population. Fifth-generation (5G) technology remains on the horizon. Internet connections in rural areas rely on vulnerable infrastructure from the state-owned internet service provider (ISP) KyrgyzTelecom. In March 2019, the Issyk-Kul region was disconnected for 13 hours after a KyrgyzTelecom fiber-optic cable was intentionally damage. 
According to the prosecutor general's office, in 2019, authorities blocked more than 100 websites and 300 accounts on social media platforms for either extremism or promoting drug use ${ }^{18}$. Online platforms, such as forums and social networks, have been used to manipulate public opinion. Trolls hired by various actors influence online discussions by expressing favorable or unfavorable views on politicians and political issues. According to Oxford University researchers, political and private actors in Kyrgyzstan use fake Facebook accounts to promote narratives favorable to the accounts' backers ${ }^{19}$.

The constitution, which was last amended in 2010, contains several legal protections applicable to online activities. However, these constitutional protections are limited in practice by a judiciary that lacks independence from the executive branch.

Article 31 of the constitution guarantees the right to freedom of thought, expression, speech, and the press. Article 29 protects privacy, including private communications shared by phone or electronic methods, and forbids collecting or disseminating confidential information without the subject's consent ${ }^{20}$.

The government's early response to the COVID-19 pandemic did not exempt journalists (except for those work-

18 G. Makanbai, В Кьргызстане заблокировали более 100 сайтов и 300 аккаунтов в соисетях [More than 100 websites and 300 accounts in social networks were blocked in Kyrgyzstan], 24.kg, February 10, 2020, https://24.kg/obschestvo/143172_vkyirgyizstane_zablokirovali_bolee_100.

19 S. Bradshaw, P.N. Howard, The Global Disinformation Order: 2019 Global Inventory of Organised Social Media Manipulation, https:// comprop.oii.ox.ac.uk/research/cybertroops2019.

20 Constitution of the Kyrgyz Republic, https://www.auca.kg/uploads/ Kyrgyz\%20Constitution\%20-\%20adopted\%20by\%20. 
ing on behalf of state-run outlets) from strict quarantine measures.

There are few restrictions on anonymous communication. Websites are not required to register, although web hosting providers must be licensed. Encryption software is freely available, and real-name registration is not required to post content or comment online. However, in 2014, the government issued a new regulation requiring service providers to sell new SIM cards only after being registered. In May 2020, the parliament debated (and later passed) a contentious bill entitled "On Information Manipulation" that would, among other things, allow the government to block "false information" without a court order. The COVID-19 pandemic saw the security services start a "witch hunt" for rumors on social media platforms. The parliament also passed restrictive amendments penalizing such rumors. The much-criticized draft bill "On Information Manipulation" would require all website owners and social media account holders to publicly identify themselves via their surname and an e-mail address ${ }^{21}$.

\section{Uzbekistan}

Several Voice over Internet Protocol (VoIP) services, including Skype, WhatsApp, and Viber, have been persistently unavailable to users in Uzbekistan since 2015. However, in May 2018, access to these services was reportedly restored. Currently, certain services are sometimes unavailable via

21 Parliament of the Kyrgyz Republic, Закон Кыргызской Pecnyблики О манипулировании информацией [Law of the Kyrgyz Republic About manipulating information], http://www.kenesh.kg/uploads/media/ default/0001/58/140520105616_\%D0\%BF\%... 
broadband or mobile internet connections. For example, in June 2019, Uztelecom customers complained that they could only access WhatsApp through a virtual private network.

In November 2018, the president signed a decree reorganizing the country's internet governance apparatus, creating the State Inspectorate for Control in the Field of Information and Telecommunications. The Technical Assistance Center collects, retains, and analyzes data from ISPs and law enforcement bodies on "threats to information security"; and a third entity helps implement the government's Safe City surveillance system. Significant blocking and filtering limit access to online content related to political and social topics, particularly sites and platforms that discuss human rights abuses in Uzbekistan.

In December 2019, journalist Katy Putz and human rights researcher Steve Swerdlow reported that they could not access the websites of the Association for Human Rights in Central Asia, the International Partnership for Human Rights, the Norwegian Helsinki Committee, and the UzbekGerman Forum for Human Rights (since renamed the Uzbek Forum for Human Rights) while in Uzbekistan Officials and Uztelecom representatives continued to insist that they were not responsible for any currently blocked websites and that those responsible for censorship in the past had been punished.

Uzbekistan's constitution protects the rights to freedom of expression and mass media, and it prohibits censorship. Article 29 of the constitution guarantees the right to gather and disseminate information ${ }^{22}$. However, in practice, these

22 Constitution of the Republic of Uzbekistan, https://president.uz/ en/constitution/english\#29. 
rights are not respected, as evidenced by the blocking websites critical of the government and the subjection of media workers to political persecution. Courts in Uzbekistan, not being independent, have largely failed to protect individuals, including journalists, against government retaliation for exercising their rights to freedom of expression.

Media workers are nominally provided strong protections under the Law on the Protection of Professional Activity of Journalists. However, these protections are not fully respected in practice. An amendment to the Law on Informatization was proposed that would grant bloggers the right to "conduct journalistic investigations", among other things, although this proposal was stalled as of May $2020^{23}$.

\section{Bibliography}

Akayeva K., Fake News on the Coronavirus Pandemic: What Do Central Asians Believe in?, Central Asian Bureau for Analytical Reporting, April 3, 2020, https://cabar.asia/ en/fake-news-on-the-coronavirus-pandemic-what-docen...

Bradshaw S., Howard P.N., The Global Disinformation Order: 2019 Global Inventory of Organised Social Media Manipulation, https://comprop.oii.ox.ac.uk/research/ cybertroops 2019 .

23 Agency of Information and Mass Communications under the Ad-

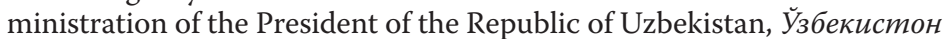
Республикасининг Айрим Қонун Хужжатларига Ўзгартирии Ва Кўшимчалар Киритиш Тўвисида [On Introduction of Amendments and Additions to Some Legislative Acts of the Republic of Uzbekistan], Regulation.gov.uz, August 3, 2019, https://regulation.gov.uz/ru/document/5679?fbclid=IwAR3nDhUbio4YhQnoZPM. 
Buttarelli G., The Commission Proposal for Regulation on E-privacy: Why Do We Need Regulation Dedicated to E-privacy in the European Union, "European Data Protection Law Review" 2017, no. 3.

de Hert P., Kloza D., Internet (access) as a new fundamental right. Inflating the current rights framework?, "European Journal of Law and Technology" 2020, no. 3.

Naranjo D., E-privacy Regulation: Good Intentions But Lot of Work To Do, "European Data Protection Law Review" 2017, no. 3.

Rojszczak M., Prawne dylematy regulacji cyberprzestrzeni: konflikt pomiędzy bezpieczeństwem narodowym a prawem do prywatności z perspektywy prawodawstwa UE i USA (The legal dilemmas of regulating cyberspace: the conflict between national security and the right to privacy from the perspective of EU and US legislation), "TEKA of Political Science and International Relations" 2018, no. 13.

Rzucidło J., Prawo dostępu do Internetu jako podstawowe prawo człowieka. część I (The right to access the Internet as a fundamental human right. Part I), "Prawo Mediów Elektronicznych" 2010.

Siemankiewicz M., Prawo Mediów Elektronicznych (Electronic Media Law).

Skepys B., Is There a Human Right to the Internet?, "Journal of Politics and Law" 2012, no. 5.

Szoszkiewicz Ł., Internet Access as a New Human Right? State of the Art on the Threshold of 2020, "Adam Mickiewicz University Law Review" 2018, no. 8. 


\begin{abstract}
The main focus of activities in a digital democracy is public participation in the exercise of public authority through the possibility of a broad debate in public forums like never before. The tasks of digital democracy and their execution in virtual reality remain open. They need to be constantly strengthened, as information and access to it becomes a special kind of public good and, at the same time, an inherent right of an individual. The condition for the preservation and development of this good is the universal and innovative management of the content disseminated through new media and the guarantee of the right of access to the ICT network, understood as the right to access the Internet, which constitutes a human right. On the one hand, some countries and international organizations consider Internet access a fundamental and universal human right; on the other hand, many governments are considering tighter control over the content and the right to block technical means of content overflow. The purpose of this paper is to describe the policy of governments and legal conditions related to the right to access the Internet in Central Asia countries. Therefore, digital media may also become a place for the implementation of very important public tasks, and the basic rules for this implementation are the principles of network regulation. The virtual space itself is more and more often governed by its own rules, and these include such principles as the right to freedom of speech, the right to development, and the unwritten rule "right of access to the Internet".
\end{abstract}

Keywords: access to the Internet, telecommunications access, human rights, freedom of the net, freedom of the speech

\begin{abstract}
Abstrakt
Głównym celem działań w zakresie demokracji cyfrowej jest udział społeczeństwa w sprawowaniu władzy publicznej poprzez możliwość szerokiej debaty na forach publicznych. Zadania demokracji cyfrowej i ich realizacja w rzeczywistości wirtualnej pozostają tematem otwartym i wymagają ciągłej redefinicji, gdyż informacja i dostęp do niej stają się szczególnym dobrem publicznym i jednocześnie nieodłącznym atrybutem jednostki. Warunkiem zachowania i rozwoju tego dobra jest nie tylko uniwersalne i innowacyjne zarządzanie treściami
\end{abstract}


rozpowszechnianymi za pośrednictwem nowych mediów, ale także gwarancja prawa dostępu do sieci teleinformatycznej, rozumianego jako prawo dostępu do sieci Internet, które stanowi prawo człowieka. $Z$ jednej strony niektóre kraje i organizacje międzynarodowe uważają dostęp do Internetu za podstawowe i powszechne prawo człowieka; z drugiej strony wiele rządów rozważa ściślejszą kontrolę nad treścią i prawo do blokowania technicznych środków przepełnienia treści. Celem artykułu jest opisanie polityki rządów oraz uwarunkowań prawnych związanych z prawem dostępu do Internetu w krajach Azji Środkowej. Trzeba podkreślić, że właśnie ten obszar mediów cyfrowych może stać się również miejscem realizacji bardzo ważnych zadań publicznych, a podstawowymi regułami tej realizacji są zasady regulacji sieci. Sama przestrzeń wirtualna coraz częściej rządzi się własnymi prawami, a wśród nich są takie zasady jak: Prawo do wolności słowa, prawo do rozwoju oraz niepisana zasada „Prawo dostępu do internetu".

Słowa kluczowe: dostęp do internetu, dostęp do telekomunikacji, prawa człowieka, wolność sieci, wolność słowa 


\section{Paulina Stanik}

\section{Martial Race Theory in the Representation of the South Asian Other in Polish World War II Accounts}

\section{Introduction}

According to the nineteenth-century ideology of 'martial races', certain groups of men were biologically and culturally predisposed to military service, e.g., the Nepalese Gurkhas, Scottish Highlanders, and Punjabi Sikhs. Between the 1880 s and 1914, the most influential theory portrayed soldiers recruited from among these groups as the manliest and most loyal army intakes ${ }^{2}$. All the racial assumptions regarding the recruited ethnic groups were published in handbooks ${ }^{3}$, which provided British officers with the information needed to gain the respect of those men. The interest in the concept snowballed after the Sepoy Rebellion in 1857 when British officers used the press to praise their 'martial'

1 Indian 'races' were in practice ethno-religious groups. O. Khalidi, Ethnic Group Recruitment in the Indian Army: The Contrasting Cases of Sikhs, Muslims, Gurkhas and Others, „Pacific Affairs” 2001, vol. 74, no. 4, p. 530 .

2 H. Streets, Martial Races, [in:] International Encyclopedia of Men and Masculinities, ed. M. Flood, London and New York, pp. 385-386.

3 For Handbooks of the Indian Army, see Vansittart (1890), Bonarjee (1899), Morris (1933). 
soldiers: "Stories that celebrated their valor, ferocity and gallantry articulated new connections between British soldiers and the most loyal Indian soldiers, and between military service in the Empire, ideal masculinity and racial superiority" were widely circulated ${ }^{4}$. The men's loyalty became a "part of sacred crusade to avenge British womanhood and to restore the honor of the British manhood"5 which would captivate the public for decades to come. The press created an image of an ideal imperial warrior and shaped the ideology according to the political needs of the military men in power eager to manipulate public opinion.

General Frederic Roberts (1832-1914), who served with the Gurkhas and the Sikhs, was convinced that the Indian Army ${ }^{6}$ should get ready to defend the Empire from a European, not a colonial enemy. He grew anxious about Russian influence in the Middle East and opted for strengthening the north-western frontier of India. By the end of the nineteenth century, the recruitment policy in the Indian Army shifted towards those ethnic groups that had stayed loyal during the 1857 rebellion. A large-scale transformation took place between 1880 and 1914 and established the hegemony of the north and north-eastern areas in the recruitment process. The northerners stood out as in the regions of southern India. The hot climate was believed to have contributed to a general racial degeneration of the population. In the southwest and

4 H. Streets, Martial Races: The Military, Race and Masculinity in British Imperial Culture 1857-1914, Manchester and New York 2010, p. 52.

5 Ibidem. In a besieged residency in Lucknow, India, British women and children were in danger of being slaughtered by the rebels.

6 Throughout the text references to the 'Indian Army' refer to the pre-1895 army, while references to the 'British Indian Army' refer to the period 1895-1947. 
southeast, it caused the 'effeminization' of men making them less capable of military service. Hence, ethnic groups originating from those regions were deemed 'non-martial'.

General Roberts' fascination with 'martial races' and his political influence made it possible for the concept to be incorporated into public discourse. What meant to be a military policy in India became a 'popular sentiment' thanks to the enormous reach of the press in the late Victorian period and the growing interest in news from the imperial frontiers ${ }^{7}$. In the end, the specific language ${ }^{8}$ used by Roberts as a discursive tool to convey his 'martial' ideals proved particularly enduring and served purposes reaching beyond countering the Russian threat to the Indian North-west. During the First World War, the theory was rather flexibly applied to recruitment as the army welcomed Muslims and Brahmin soldiers in the ranks and drew recruits from many other regions previously deemed non-martial ${ }^{9}$. In spite of the disappearance of the 'martial' army by the Second World War ${ }^{10}$, the theory prevailed as a 'habit of mind'11. In the 1940s, the

7 H. Streets, Martial Races: The Military..., op.cit., pp. 93-119; D.M. Peers, Those Noble Exemplars of the True Military Tradition; Constructions of the Indian Army in the Mid-Victorian Press, „Modern Asian Studies" 1997, vol. 31, no. 1, pp. 109-142.

8 Ibidem, pp. 138-140. Roberts often used adjectives such as gallant, admirable, disciplined, bold, loyal, honourable, heroic etc. to describe the Gurkhas, the Sikhs, and the Highlanders.

9 R. Kaushik, Indian Army and the First World War 1914-1918, Oxford 2019, p. 52; G. Rand, K.A. Wagner, Recruiting the 'martial races': identities and military service in colonial India, „Patterns of Prejudice” 2012, vol. 46, no. 3-4, pp. 232-254.

10 L. Caplan, 'Bravest of the Brave': Representations of 'The Gurkha' in British Military Writings, „Modern Asian Studies” 1991, vol. 25, no. 3, p. 586; G. Rand, K.A. Wagner, op.cit.

11 D. Omissi, 'Martial Races': Ethnicity and Security in Colonial India 1858-1939, „War \& Society” 1991, vol. 9, no. 1, pp. 21-22. 
term 'martial races' embraced the Punjabi Muslims, Hindu Jats, Sikh Jats, the Dogras, the Pathans, some Marathi casts, and the Rajputs. In line with imperial propaganda and the military agenda, regimental ties and traditions in the martial units had to be strengthened to preserve morale. Conversely, the men from the newly-included groups saw the armed forces solely as a source of employment and joined for economic and non-patriotic reasons ${ }^{12}$.

During the First World War, the soldiers in the British Indian Army were present on the Western Front and in the Middle East. Thus, it was unlikely that they came into contact with soldiers of Polish origin serving in the imperial armies of Russia, Germany, and Austro-Hungary concentrated along the Eastern Front. While Piotr Nykiel managed to trace only a few Polish soldiers at Gallipoli and Dardanelles ${ }^{13}$, there must have been many more men fighting for the Central Powers on the Western Front ${ }^{14}$. The lack of personal narratives concerning the said war theatres makes it impossible to establish the extent of the Indo-Polish encounters. Conversely, the British had had a long-standing relationship with the Indian Army, additionally reinforced by the Indian contribution to the Great War. Letters by Indian soldiers from military hospitals in Britain reveal how they were made feel welcomed, treated with respect and

12 S. Bhattacharya, British Military Information Management Techniques and the South Asian Soldier: Eastern India during the Second World War, „Modern Asian Studies” 2000, vol. 34, no. 2, pp. 490-496.

13 P. Nykiel, Soldiers of Polish Origin in the Dardanelles 1915-1918, „Yakın Dönem Türkiye Araştırmaları” 2015, vol. 14, pp. 349-354.

14 For instance, Bohdan Hulewicz wrote a memoir including his account of the Battle of the Somme (1973). See also Śliwiński (2014), Kaczmarek (2014), Dębska (2014). 
dignity $^{15}$. The British first-hand experience of fighting alongside the Indian soldiers during and after the First World War cannot be compared with the lack of it in interwar Poland. Helen Streets argues that the discourse was manufactured to achieve specifically British political outcomes such as improving the army's image or to counter the rise of nationalism in India and Ireland ${ }^{16}$. Correspondingly, it should have largely been absent from the Polish imagination in the early twentieth century.

\section{Martiality in the Polish Personal Narratives}

In the analysis of the representation of the Gurkha soldiers in British military writing, Lionel Caplan concentrates on their martiality and loyalty ${ }^{17}$. Similarly, Pradeep Barua concludes that the Victorians selected the 'martial' groups according to the climate, physical qualities, and behavioral characteristics $^{18}$. He argues that the British recruitment policy was determined by assumptions of the climate conditions in India. Throughout the nineteenth century, the British residing in the subcontinent were constantly reminded of the dangers of a prolonged stay in the hot climate of India. Conversely, the North offered a much-desired escape

15 D. Omissi, Europe Through Indian Eyes: Indian Soldiers Encounter England and France, 1914-1918, „The English Historical Review” 2007, vol. 122, no. 496, pp. 371-396.

16 H. Streets, Martial Races: The Military, Race and Masculinity in British Imperial Culture 1857-1914, Manchester and New York 2010.

17 L. Caplan, Warrior Gentlemen: 'Gurkhas' in the Western Imagination, Providence/Oxford 1995.

18 P. Barua, Inventing Race: The British and India's Martial Races, „The Historian” 1995, vol. 58, no. 1, p. 112. 
and shelter from the dreaded heat. Consequently, the image of the north-western communities was more positive. They were seen as having much in common with the Europeans and, therefore, egalitarian and superior to the southerners ${ }^{19}$.

Caplan argues that the Gurkhas became "honorary Europeans' thanks to their similarity to the British officer class - a privilege the Indians could not enjoy. Furthermore, he labeled them as 'warrior gentlemen' who are concomitantly an embodiment of masculinity and gentle and courteous soldiers. In the Polish memoirs, the Indian servicemen are frequently reminded about their subordinate status by the British. Conversely, the Gurkhas are always regarded with respect and are never subject to mistreatment. Tadeusz Bodnar scrutinizes the Anglo-Indian relations while in Cairo and notes: "The Indians keep together and sit far from the whites as if they were afraid of them. Or, perhaps, they sense their inferiority and know that a Briton could beat them up with a stick"20.

Similarly, Bronisław Dzikiewicz observes that the British, "who consider themselves to be of a better sort", stay away from the Indians ${ }^{21}$. The author, an assistant of an Indian officer of the British Army during training, had an opportunity to learn more about the complex cross-cultural relations in the army. He writes: "While having a drink, he [the officer] confessed [emphasis added] that he is Indian and that he serves in the British Army just because he has a $\mathrm{PhD}$ in

19 Ibidem, pp. 108-109.

20 T. Bodnar, Znad Niemna przez Sybir do II Korpusu, Wrocław 1997, p. 264.

21 B. Dzikiewicz, Z teodolitem pod Monte Cassino, Warsaw 1984, p. 52 . 
Mathematics and is married to an Englishwoman"22. Dzikiewicz unwittingly implies that service in the British Army is not only regarded higher than in the British Indian Army but also that it is difficult to secure for non-Europeans. In the study of the relations between native soldiers and British officers in the Indian Army, Jeffrey Greenhut argues that the latter believed they were "inherently, racially, superior to the Indians. A British officer might love, even admire, his men, but he never forgot, nor was he allowed to forget by the tight circle of the mess, that he was innately better than his men"23. In the Polish accounts, such hierarchies do not apply to the Nepalese soldiers; the British are remembered telling stories about the Gurkhas' bravery and never seen disrespecting them.

The soldiers' martiality is linked to their skill in the mountains, which is commonly associated with their place of origin. By being exposed to high altitudes and harsh weather conditions, the men are sturdier and more resilient. Bodnar, who believed that the Gurkhas came from India, was not the only Polish author who had inaccurately placed the Nepalese on the map; Eryk Nanke refers to the Gurkhas as soldiers from Tibet ${ }^{24}$. Only Aleksander Grobicki pinpoints the correct location ${ }^{25}$. However, it is noteworthy that Grobicki had studied in England before the war and might have been more familiar with the British military discourse and imperial history. In conclusion, all authors who

22 Ibidem.

23 J. Greenhut, Sahib and Sepoy: An Inquiry into the Relationship between the British Officers and Native Soldiers of the British Indian Army, „Military Affairs” 1984, vol. 48, no. 1, p. 17.

24 E. Nanke, Cena Bycia Innym, Kraków 2000, p. 120.

25 A. Grobicki, Żołnierze Sikorskiego, Kraków 1989, p. 114. 
mention the soldiers' place of origin correctly situated it in the Himalayas, thus linking the Gurkhas' superior mountain skills with their place of origin.

Tadeusz Bodnar, who produced the most detailed description of the Nepalese, explicitly refers to the Gurkhas as "good soldiers, very efficient in the mountains" 26 . In his memoir, this observation comes right after the author's reminiscence of being led by a Gurkha through a danger zone at Monte Cassino ${ }^{27}$. The first-hand experience in the rugged terrain might have influenced Bodnar's assumption more than the actual 'martial race' discourse, all the more so since the author had a limited command of English. Furthermore, the role of a guide assigned to the Gurkha might not have seemed accidental to Bodnar, for the Nepali effortlessly dealt with the situation. The Gurkhas' skill in mountain warfare was also noted by Melchior Wańkowicz, who listed some of the historical highland campaigns the Nepalese took part in, namely "the mountains of Afghanistan, Syria, Abyssinia, and Tunis"28. Yet another element of the martial race discourse can be seen in Mieczysław Pruszyński's account of a conversation with a British major. The man said, "We [the Army] believe that it'd be a waste to use the Poles in a desert - the Aussies and the Indians will do better [there]"29. The statement could indicate the presence of the 'climatic element' in the British approach to operations.

Polish authors rarely distinguished among the diverse peoples of India whom they tended to collectively call Indi-

26 T. Bodnar, op.cit., p. 286.

27 Ibidem, p. 279. All translations from Polish are mine.

28 M. Wańkowicz, Bitwa o Monte Cassino, Warsaw 2009, p. 23.

29 M. Pruszyński, W Narwiku, Tobruku i Moskicie, Warsaw 1957, p. 248. 
ans [Polish: Hindusi]. According to the martial race theory, the Indian and the Nepalese societies were divided into martial and non-martial ethnic groups. In India, regiments and battalions were often named after the regions the soldiers had originated from. The 'regional' distinction was important for the ideology favored some geographical locations over others. For the Poles, it was possible to remember and refer to specific Indian units instead of using the collective term 'Indians'. In this case, the Poles' occasional reference to the Sikhs, who "were one of the most celebrated 'martial classes' in India, acknowledged as the 'flower' of the Indian Army ${ }^{30}$ by the British themselves" and "the backbone of the British Indian Army", is the exception that proves the rule. In general, their or the Indians' origin is never enquired about in the Polish Second World War memoirs, making the link between the 'martiality' and the Indian military personnel impossible to establish.

The Gurkhas, apart from being assumed to be physically predisposed to war, were also seen to possess behavioral characteristics which made them the best soldiers. First and foremost, they are known to be brave, particularly in the face of the enemy. An indispensable element of the image of the fearless Gurkha was the khukuri knife. The curved dagger - represented as a national weapon - features in the regimental insignia of all Gurkha units and is carried by the soldiers in addition to the standard military equipment. References to the khukuri are a recurring theme in the descriptions of the Gurkhas. Bodnar was intrigued by its unique shape and the skill with which the Gurkhas used it.

30 R.K. Mazumder, From Loyalty to Dissent: Punjabis from the Great War to World War II, [in:] The Indian Army in the Two World Wars, ed. R. Kaushik, 2012, p. 485. 
He had witnessed the Nepalese using the knives to mercykill wounded mules at Cassino ${ }^{31}$. Additionally, Nanke recalls the Gurkha ritual connected to it: "According to their custom, a knife drawn in battle has to taste blood. Therefore, the soldier has to cut himself before returning it to its sheath if the knife wasn't used"32. Since Nanke spoke fluent English, he had likely learned about the practice from his British counterparts.

Ever since native soldiers of the British Indian Army became eligible for the Victoria Cross in 1911, courage has become measurable. Ten out of the thirteen decorations awarded to the Nepalese had been won during the Second World $\mathrm{War}^{33}$. Since in the wake of Indian independence, 'martiality' was deemed a colonial tool of subjugation, the Gurkhas' were to become permanently associated with "valor or gallantry performed in the face of the enemy" instead. Although Victoria Cross does not appear in Polish memoirs, the Gurkhas are, however, often described as 'brave' [Polish: dzielny] by the veterans. Grobicki writes:

As I'm walking along Cavendish Road, I see inky caves with German soldiers' legs sticking out of them. All around, there are remains of the English, the New Zealanders, and the tiny but brave Gurkhas ${ }^{34}$.

Similarly, Henryk Panas, in his description of the second Allied attempt to conquer Monte Cassino (February 15-18, 1944) states that "the English, the Indians, brave to the point

31 T. Bodnar, op.cit., p. 285.

32 E. Nanke, op.cit., p. 120.

33 Ch.B. Gurung, British Medals and Gurkhas, Kathmandu 1998, pp. 33-34.

34 A. Grobicki, Żotnierze Sikorskiego, Kraków 1989, p. 183. 
of madness Gurkhas and no less daring Maori ${ }^{35}$ - did not manage to succeed"36. It can be assumed that both authors were familiar with the British military discourse as they had not witnessed the Nepalese in battle. Górski, when describing the Allied forces, refers to the 'fearless' Gurkhas, whom he encountered alongside the 'distinguished' $4^{\text {th }}$ Indian Divi$\operatorname{sion}^{37}$.

Additionally, there is a link between faith and lack of fear in Bodnar's memoir. The author writes, "their [the Gurkhas'] religion assured that death in battle would send their soul straight to heaven" ${ }^{\prime 3}$. Religion played a significant role in the 'martial race' discourse as it was used as a tool of differentiation by the British; the imperialists perceived it as an obstacle to the efficient functioning of the army. The Gurkhas, according to Caplan, "had rejected the shadow of their religion, retaining only its substance", which made them better soldiers $^{39}$. This aspect of the Nepalese distinguished them from the non-martial Indians from the plains who followed their religious beliefs and were thus assumed to be less capable/willing? of carrying out orders ${ }^{40}$. In the Polish Second World War memoirs, the Indians are portrayed as rather

35 Also the Maori were considered to be naturally predisposed to war. The matter has been discussed in New Zealand ever since the Great War and their participation in the Gallipoli Campaign. F. Walker, 'Descendants of a Warrior Race': the Maori Contingent, New Zealand Pioneer Battalion, and Martial Race Myth, 1914-19, „War \& Society” 2012, vol. 31, no. 1, pp. 1-21.

36 H. Panas, Jak mi byto u Andersa, Warsaw 1988, p. 200.

37 W. Górski, Żotnierskim szlakiem przez Tobruk i Monte Cassino, Warsaw 1991, p. 71.

38 T. Bodnar, op.cit., p. 286.

39 L. Caplan, Warrior Gentlemen..., op.cit., p. 192.

40 Ibidem. 
demanding in terms of dietary restrictions ${ }^{41}$. Conversely, the Gurkhas' diet is never discussed, thus contributing to their image of ideal soldiers with basic needs.

The analysis has shown that masculinity and bravery emphasized in the representation of the Gurkhas do not characterize the Indians. It is, in fact, more difficult to establish a link between the Indian people and the martial race theory in the Polish war memoirs. There appears to be no pattern in the portrayal of the Indians following face-to-face encounters. Some authors mention their physical prowess ${ }^{42}$, and some describe them in opposite terms ${ }^{43}$. Marek Jelita Czerkawski, who served in the Polish Independent Carpathian Rifle Brigade alongside the $4^{\text {th }}$ Indian Division in North Africa, describes the Indians as warrior-like soldiers. He writes:

An Indian, unlike the soldiers of the Carpathian Brigade, is a professional soldier. The olive skin complexion, the exotic appearance, long hair reaching the waist, thick black beards, and a fancy mustache make them look like descendants of warlike tribes. Discipline is what denotes the Indian soldier ${ }^{44}$.

The link between masculinity and appearance may be arising from the representations of the Oriental military traditions in which "conflicts with strange enemies, endlessly recalled and mythologized in art, literature, and film, help

41 W. Lasocki, Przez tundre i pustynie, London 1993, p. 118; M. Jelita-Czerkawski, op.cit., p. 92.

42 J. Ciemnołoński, $W 2$ Korpusie to byto... czyli Coś $w$ rodzaju reportażu, Kraków 1983, p. 127; J.H. Janczak, Przez śniegi Kottubanki i piaski Kermine, Warsaw 1991, p. 181.

43 A. Grobicki, op.cit., pp. 112-113.

44 M. Jelita-Czerkawski, Wspomnienia 'Ramzesa': Tobruk - El Gazala - Monte Cassino - Bolonia, Lublin 1995. 
define the West's cosmology"45. Drawing on Samuel Huntington's Clash of Civilisations ${ }^{46}$, Porter claims that war has been a constant source of Western fascination ever since recorded history began. He argues that conflicts allow communities to self-define opposite the Other, thus making war a relevant site of Orientalism. The division into the Western and the Eastern way of war is present in Czerkawski's account. The author perceives Indians as Others $t$ and represents them in the Orientalist mode instead of focusing, for instance, on them being an ally.

It is noteworthy that in Czerkawski's account, the warlike-looking Indians are constrained by military discipline. The situation is an indicator of the existing power-knowledge relations relevant to Orientalism ${ }^{47}$ and the ideology of martial races. According to Caplan, "by the early nineteenth century, the view was widespread in India that native troops could flourish only under British officers" as natives were considered lacking adequate leadership skills ${ }^{48}$. What is more, the Gurkhas' skills, if uncontrolled, were believed to pose a danger to the soldiers themselves and everyone around them. The soldiers of the alleged martial groups were deemed simple-minded and therefore unconcerned with geopolitical matters, eager to do any battle for the Crown ${ }^{49}$. In the British military discourse on the Gurkhas, the patronizing manner can be seen, for instance, in the use

45 P. Porter, Military Orientalism: Eastern War through Western Eyes, London 2009, p. 3.

46 S.P. Huntington, The Clash of Civilizations and the Remaking of World Order, New York 1996.

47 E. Said, Orientalism, London 1978.

48 L. Caplan, op cit., 579.

49 Idem, Warrior Gentlemen, op.cit., p. 146. 
of diminutives or animal metaphor ${ }^{50}$. Interestingly, they can also be found in the Polish memoirs where the Gurkhas are portrayed as 'tiny' and compared to tigers ${ }^{51}$. In Caplan's view, the fact that the Nepalese had to be controlled was a sign of the men's loyalty, which along with martiality, was a key element of the ideology ${ }^{52}$.

The Poles never straightforwardly elaborate on the loyalty' of the South Asians. In the memoirs, only the list of highland battles mentioned by Wańkowicz could be interpreted as a sign of the Gurkhas' allegiance to the British. Why the Nepalese soldiers served in the British-Indian Army is the question never posed, as if their support was taken for granted $^{53}$. Considering how the authors paid little attention to the ethnic composition of the army, they may have been unaware of Nepal's sovereignty and may have considered the Gurkhas' aid to Britain a colonial entanglement. It can be assumed that the resistance of the Polish soldiers to the image of an Indian warrior may be linked to its absence in the European public sphere, particularly when compared with the Gurkhas, who have been an integral part of the modern British Army ${ }^{54}$. Furthermore, the distinction might have stemmed from the British-Indian Army soldiers' relations with the British (as observed by the Poles first-hand) or been influenced by the variety of roles performed by the Indians in the army, of which many were essentially non-martial.

50 Idem, op.cit., p. 587.

51 A. Grobicki, op.cit., p. 183; T. Bodnar, op.cit., p. 279.

52 Ibidem, 587.

53 Like in the British discourse on the Gurkhas. L. Caplan, op.cit., p. 588 .

54 See the history of service of the British Army's Brigade of Gurkhas. 
In the Polish memoirs, the Gurkhas appear mainly in the military context. Conversely, the Indians emerge also in various non-combatant roles. Yasmin Khan points to that largely overlooked group of people working behind the scenes of the Second World War theatres: "There were millions of other South Asians working toward the imperial war effort, and we never hear about them. It wasn't glamorous work: 'coolies' loading and unloading cargo at imperial ports or clearing land for aerodromes did not share the prestige of fighter pilots. But their work could be very dangerous" ${ }^{\prime 5}$. In the British Indian Army, the rear-echelon units consisted of signalers, carriers, pioneers, and mess servants ${ }^{56}$. Individual regiments were supported by non-combatants, or camp followers, performing essential jobs such as cooking, sweeping, or water-carrying. Many of them came from lower castes and lied about their age to be employed in the army. Employment opportunities, however, opened also for the educated middle-classes required by the army to "fight a technologically modern war" 57 .

Most of the Indians the Poles encountered during the Second World War performed menial jobs such as cooking, cleaning, and driving. Bogusław Harok remembers being served by the Indians in a canteen after arriving at a camp near the port city of Pahlavi (today's Iran) ${ }^{58}$, and Franciszek Slusarz complains about the Indian cooks preparing food

55 Y. Khan, Has India's Contribution to WW2 Been Ignored?, BBC News, 17 June 2015.

56 A. Jeffreys, J.P. Rose (eds.), The Indian Army, 1939-47: Experience and Development, 2012, p. 13.

57 S. Bhattacharya, op.cit, p. 490.

58 B. Harok, Bytem tam: wspomnienia weterana II wojny światowej, Katowice 2017, pp. 203-204. 
at the military hospital in Khanaqin, Iran ${ }^{59}$. While in Baghdad, Iraq, Aleksander Topolski recalls his stay in a camp 'equipped with residential tents with mosquito nets and kitchens run by Indian soldiers of the Royal Indian Army Service Corps' ${ }^{\prime 60}$. The Indian kitchen staff was also present on a troopship to Liverpool ${ }^{61}$. Another essential service run by the Indians was cleaning tents in an Iranian camp ${ }^{62}$. In his memoir, Michał Bron recalls being driven by an Indian from Haifa (present-day Israel) to Baghdad, Iraq ${ }^{63}$. Similarly, Władysław Mazur traveled across the desert from Tehran, Iran, to Habbaniyah, Iraq, with an Indian driver and was accompanied by an Indian military escort ${ }^{64}$.

The Poles had an opportunity to encounter Indian medical staff after the evacuation from the Soviet Union to Iran. Mohammad Ata-Ullah, a Pakistani doctor in the rank of Lieutenant Colonel in charge of the 22nd Indian Medical Regiment overseeing the 'Operation Pole-Evac', anxiously describes the reception of the first evacuees. When the people arrived, the Indian staff ordered them to get washed and equipped with utensils. Bogusław Harok ${ }^{65}$ and Franciszek Slusarz ${ }^{66}$, just as thousands of other Poles, passed through two camps set up for them by the military: the 'dirty' and the 'clean' one. Both

59 F. Slusarz, Przez Kazachstan do Argentyny: wspomnienia żotnierza 2. Korpusu, Warsaw 2015, p. 97.

60 A. Topolski, Bez dachu: moje wojenne przeżycia na Bliskim Wschodzie i we Wtoszech, Poznań 2012.

61 E. Gruda, Trudny powrót, Warszawa 1969, p. 203.

62 J.H. Janczak, Przez śniegi Kottubanki i piaski Kermine, Warsaw 1991, p. 181.

63 M. Bron, Nie szukałem przygód, Warsaw 1982, p. 141.

64 W. Mazur, Wyspy ostatniej nadziei, Rzeszów 1987, p. 105.

65 B. Harok, op.cit., pp. 203-204.

66 F. Slusarz, op.cit., p. 95. 
authors remember that the Indians were responsible for disposing of their lice-infested clothing. Indian medical staff also worked in the camp in Khanaqin, where the Polish soldiers were transferred from Iran. Slusarz, who felt unwell after a long journey, was attended to by an Indian doctor while staying at a 'small British military hospital'67.

The Indians also appear in other professional roles in the Polish war narratives. Since the army needed land surveyors, Bronisław Dzikiewicz, a professional surveyor in interwar Poland, was sent for training to an Indian company stationed near Hamadan, Persia. There he worked alongside the British and the Indians from the $4^{\text {th }}$ Indian Field Survey Company before joining the newly-created $12^{\text {th }}$ Geographic Company of the Polish II Corps (12. Kompania Geograficznej II Polskich Sit Zbrojnych na Zachodzie). During the course, Dzikiewicz observed the methods and the tools used by the company's surveyors. He recalls being impressed by the skill of the Indians who worked on topographic maps in 1: 2500 scale by photogrammetric methods ${ }^{68}$. On another occasion, however, he was surprised by the fact that the surveyors used outdated instruments. His interlocutor claimed that Indian topographers lacked the professional skills needed to operate newer equipment ${ }^{69}$.

\section{Conclusions}

In light of the analysis, there is a significant difference in the portrayal of the Gurkhas and the Indians through the lens

\footnotetext{
67 F. Slusarz, op.cit., p. 97.

68 B. Dzikiewicz, op.cit., p. 52.

69 Ibidem, p. 53.
} 
of martiality. Although there might have been some confusion regarding the ethnicity of the British Indian Army soldiers, the Nepalese are seen as exceptionally skilled and fearless soldiers. Their abilities are linked to their place of origin, situated somewhere in the Himalayas, and frequently mentioned by the authors. The image of the Indians appears to be influenced by the nature of the jobs they did in the army. Conversely, the Gurkhas are remembered performing mainly operational tasks, which adds to their warrior-like image. It can be assumed that the latter retained their martial identity not only for that reason but also because of the attitude of the British towards them, as observed first-hand by the Poles. The Indians largely lack martial characteristics despite having a similarly long history of military service for the Crown. Also, the authors who spoke English seemed to have been more familiar with the concept of martiality, which was developed to support British imperialism in the nineteenth century, pointing to the persistence of the discourse in the back-then army. Overall, the Poles contribute to the British discourse on the Gurkhas as a 'warrior race' thanks to their participation in the Allied effort and close cooperation with the British Army during the conflict. The myth of the martial Gurkhas and the ethnicity-based recruitment to the Indian Army survived the Indian independence and has been a part of the popular discourse ever since its propagation ${ }^{70}$.

70 P. Barua, op.cit.; A. Chisholm, Marketing the Gurkha Security Package: Colonial Histories and Neoliberal Economies of Private Security, „Security Dialogue” 2014, vol. 45, no. 4, pp. 349-372; T. Gurung, The Making of Gurkhas as a 'Martial Race' in Colonial India: Theory and Practice, „Proceedings of the Indian History Congress” 2014, vol. 75, pp. 520-529 . 


\section{Bibliography}

Ata-Ullah M., Citizen of Two Worlds, New York 1960.

Barua P., Inventing Race: The British and India's Martial Races, "The Historian" 1995, vol. 58, no. 1.

Bhattacharya S., British Military Information Management Techniques and the South Asian Soldier: Eastern India during the Second World War, "Modern Asian Studies" 2000, vol. 34, no. 2.

Bodnar T., Znad Niemna przez Sybir do II Korpusu, Wrocław 1997.

Bonarjee P.D., A Handbook of the Fighting Races of India, Calcutta 1899.

Bron M., Nie szukatem przygód, Warsaw 1982.

Caplan L., 'Bravest of the Brave': Representations of 'The Gurkha' in British Military Writings, "Modern Asian Studies" 1991, vol. 25, no. 3.

Caplan L., Warrior Gentleman: 'Gurkhas' in the Western Imagination, Providence/Oxford 1995.

Chisholm A., Marketing the Gurkha Security Package: Colonial Histories and Neoliberal Economies of Private Security, "Security Dialogue" 2014, vol. 45, no. 4.

Ciemnołoński, J., W 2 Korpusie to byto... czyli Coś w rodzaju reportażu, Kraków 1983.

Czerkawski M., Wspomnienia 'Ramzesa': Tobruk-El Gazala - Monte Cassino - Bolonia, Lublin 1995.

Dębska A., Polski wir I wojny, Warsaw 2014.

Dzikiewicz B., Z teodolitem pod Monte Cassino, Warsaw 1984.

Górski W., Żotnierskim szlakiem przez Tobruk i Monte Cassino, Warsaw 1991.

Greenhut J., Sahib and Sepoy: An Inquiry into the Relationship between the British Officers and Native Soldiers of 
the British Indian Army, "Military Affairs" 1984, vol. 48, no. 1.

Grobicki A., Żotnierze Sikorskiego, Kraków 1989.

Gruda E., Trudny powrót, Warsaw 1969.

Gurung Ch.B., British Medals and Gurkhas, Kathmandu 1998.

Gurung T., The Making of Gurkhas as a 'Martial Race' in

Colonial India: Theory and Practice, "Proceedings of the Indian History Congress" 2014, vol. 75.

Harok B., Bytem tam: wspomnienia weterana II wojny światowej, Katowice 2017.

Hulewicz B., Wielkie wczoraj w małym kręgu, Warsaw 1973. Huntington S.P., The Clash of Civilizations and the Remaking of World Order, New York 1996.

Janczak J.H., Przez śniegi Kottubanki i piaski Kermine, Warsaw 1991.

Jeffreys A., Rose J.P. (eds.), The Indian Army, 1939-47: Experience and Development, Ashgate 2012.

Kaczmarek R., Polacy w armii kajzera: na frontach pierwszej wojny światowej, Kraków 2014.

Kaushik R., Indian Army and the First World War 1914-1918, Oxford 2019.

Khalidi O., Ethnic Group Recruitment in the Indian Army:

The Contrasting Cases of Sikhs, Muslims, Gurkhas and Others, "Pacific Affairs" 2001, vol. 74, no. 4.

Khan Y., Has India's Contribution to WW2 Been Ignored?,

BBC News, 17 June 2015, www.bbc.com, https://www.

bbc.com/news/world-asia-india-33105898.

Kwoczyński J., Wojenne Gwiazdy, Warsaw 2002.

Lasocki W., Przez tundre i pustynie, London 1993.

Mazumder R.K., From Loyalty to Dissent: Punjabis from the Great War to World War II, [in:] The Indian Army in the Two World Wars, ed. R. Kaushik, 2012. 
Mazur W., Wyspy ostatniej nadziei, Rzeszów 1987.

Morris C.J., The Gurkhas, A Handbook for the Indian Army, Delhi 1933.

Nanke E., Cena Bycia Innym, Kraków 2000.

Nykiel P., Soldiers of Polish Origin in the Dardanelles 1915-1918, „Yakın Dönem Türkiye Araştırmaları” 2015, vol. 14.

Omissi D., Martial Races: Ethnicity and Security in Colonial India 1858-1939, "War \& Society" 1991, vol. 9, no. 1.

Omissi D., Europe Through Indian Eyes: Indian Soldiers Encounter England and France, 1914-1918, "The English Historical Review” 2007, vol. 122, no. 496.

Panas H., Jak mi byto u Andersa, Warsaw 1988.

Peers D.M., Those Noble Exemplars of the True Military Tradition; Constructions of the Indian Army in the Mid-Victorian Press, "Modern Asian Studies" 1997, vol. 31, no. 1. Porter P., Military Orientalism: Eastern War through Western Eyes, London 2009.

Pruszyński M., W Narwiku, Tobruku i Moskicie, Warsaw 1957. Ramachandran D.P., The Doctor-Heroes of War, "The Hindu", 19 March 2017, www.thehindu.com, https://www. thehindu.com/opinion/open-page/the-doctor-heroes-ofwar/article17529390.ece.

Rand G., Wagner K.A., Recruiting the 'martial races': identities and military service in colonial India, "Patterns of Prejudice" 2012, vol. 46, no. 3-4, pp. 232-254.

Said E., Orientalism, London 1978.

Streets H., Martial Races, [in:] International Encyclopedia of Men and Masculinities, ed. M. Flood, London and New York 2007.

Streets H., Martial Races: The Military, Race and Masculinity in British Imperial Culture 1857-1914, Manchester and New York 2010. 
Śliwiński E., Potudniowo-Zachodnia Wielkopolska w latach I wojny światowej: wybór źródet, Łódź 2014.

Slusarz F., Przez Kazachstan do Argentyny: wspomnienia żotnierza 2. Korpusu, Warsaw 2015.

Topolski A., Bez dachu: moje wojenne przeżycia na Bliskim Wschodzie i we Wtoszech, Poznań 2012.

Vansittart E., Notes on the Goorkhas, being a short account of their country, history, characteristics, clans, etc., Calcutta 1890.

Walker F., 'Descendants of a Warrior Race': the Maori Contingent, New Zealand Pioneer Battalion, and Martial Race Myth, 1914-19, "War \& Society" 2012, vol. 31, no. 1.

Wańkowicz M., Bitwa o Monte Cassino, Warsaw 2009.

\begin{abstract}
According to the nineteenth-century ideology of 'martial races', some ethnic groups were biologically and culturally predisposed to war. Serving alongside the British Indian Army in the Second World War, Polish soldiers were exposed to the theory, which may have affected the image of the South Asians during the war. The paper aims to answer whether any of its elements were present in the portrayal of the Indian and the Gurkha soldiers encountered in the stated period. The research material consists of excerpts from selected Polish Second World War personal narratives. A content analysis centered around two main strands of the theory - martiality and loyalty - revealed that elements of the imperial martial race discourse reached Polish servicemen and influenced their representation of the South Asians.
\end{abstract}

Keywords: personal narrative, World War II, British Indian Army, martial race theory, Poland, Gurkhas 


\begin{abstract}
Abstrakt
Według XIX-wiecznej ideologii „ras wojennych” niektóre grupy etniczne były biologicznie i kulturowo predysponowane do wojny. Polacy służący w brytyjskiej „armii indyjskiej” w czasie drugiej wojny światowej byli bezpośrednio wyeksponowani na działanie tej teorii, co mogło wpłynąć na ich wojenny obraz Azjatów z południa. Celem pracy jest udzielenie odpowiedzi na pytanie czy elementy teorii pojawiły się w polskich przekazach na temat Hindusów i Gurkhów z tamtego okresu. Materiał badawczy to zbiór fragmentów polskich narracji osobistych pochodzących z czasów drugiej wojny światowej. Analiza treści tych materiałów skupiona na dwóch biegunach teorii - „wojowniczości” oraz lojalności - wykazała, że elementy imperialnego dyskursu „ras wojennych” sięgnęły polskich żołnierzy i wpłynęły na ich obraz wojowników pochodzących z południowych kresów Azji.
\end{abstract}

Słowa kluczowe: narracja osobista, II wojna światowa, brytyjska „armia indyjska", teoria ras wojennych, Polska, Gurkhowie 


\section{Marzena Toumi}

Akademia Sztuki Wojennej

ORCID ID: https://orcid.org/0000-0003-3838-1315

\section{Aleksander Olech}

Akademia Sztuki Wojennej

ORCID ID: https://orcid.org/0000-0002-3793-5913

\section{Saudi Cybersecurity Strategy}

My first objective is for our Nation to be a successful and pioneering role model in the world at all fronts, and I will work with you to achieve it. The Custodian of the Two Holy Mosques King Salman Bin Abdulaziz Al Saud

\section{Introduction}

Saudi Arabia is the largest country in the Arabian Peninsula and one of the few absolute monarchies in the world. Saudi Arabia is governed by the king and prime minister, Salman ibn Abd al-Aziz Al Su'ud. Until recently, Saudi Arabia was associated only with substantial oil resources and a radical part of Sunni Islam - Wahhabism. Today, it is rapidly modernizing and opening up to the world.

The largest economy in the Arab world is trying to diversify its economy, which has been hit hard by low oil prices and the COVID-19 crisis. In late 2020, the king approved Riyadh's new strategy for artificial intelligence. Data is set to be the new fuel for Saudi Arabia's economy, and the government is betting on cloud computing. "This strategy requires the collaboration of both public and private business sectors 
to leverage AI data and initiatives and help the Kingdom become one of the world's leading countries in this field", said Dr. Abdullah ibn Sharaf Al-Ghamdi, president of the Saudi Intelligence Agency. Data and Artificial Intelligence (SDAIA).

New technologies are to improve both the government's effectiveness and efficiency (the Kingdom intends to use AI to provide advanced services to its citizens) and the private sector, stimulate entrepreneurship, and support young people - provisions on this subject were included in the AI strategy approved by the king. The young generation is expected to play a unique role in this plan, and adequate education efforts are therefore key to the strategy's success.

In Saudi Arabia, 70\% of the population (less than 32 million people) is under 30. This demographic group is aimed at the actions of the Saudi government as part of the 2016 strategy - Saudi Vision 2030, an ambitious project of socioeconomic transformation ${ }^{1}$. It emphasized that the Kingdom of Saudi Arabia (KSA) intends to reduce its dependence on oil, diversify its economy and develop public service sectors such as health, education, infrastructure, recreation, and tourism. At the core of this initiative is a focus on technology, digital transformation, and the development of digital infrastructure. The strategy itself does not deal with cyberspace and cyberterrorism ${ }^{2}$, but the directions of changes are indicated. It should be emphasized that Saudi Arabia has the largest Information and communications technology (ICT)

1 This project was initiated by Mohammad bin Salman (heir to the throne, deputy prime minister and minister of defense - de facto ruling Riyadh, one of the most influential people in the world according to the Forbes chart) in response to two major trends facing the kingdom: falling oil prices and demographic challenges.

2 Kingdom of Saudi Arabia, Saudi Vision 2030, Riyadh 2016. 
market in the Middle East. In 2016, \$15 billion was invested in the ICT sector, including cybersecurity ${ }^{3}$.

However, the development of digital technologies also carries a powerful threat, so ensuring cybersecurity is a priority for many countries and determines their national security.

\section{Cyberterrorism Threats}

Saudi Arabia, like any other country in the world, is struggling with cyberattacks every day. Due to its international position and resources, it is attacked much more often than other countries in the region. Such intensification of threats causes difficulties in the functioning of both the public and private sectors. Cyber-attacks cause severe damage to the economy and negatively affect the social and political stability of the country. In addition, cybercrime is also one of the main causes of a huge loss of money and image.

In 2012 alone, the Kingdom lost $\$ 693$ million, and this amount is higher every year ${ }^{4}$. In 2020, Saudi Arabia recorded over 22.5 million such attacks ${ }^{5}$, each costing the state $\$ 6.5$ million $^{6}$, while in the first quarter of 2021, over 7 million cy-

3 M. Hathaway, F. Spidalieri, F. Alsowailm, Kingdom of Saudi Arabia cyber readiness at a glance, Potomac Institute for Policy Studies 2017, p. 19.

4 A. Quadri, M.K. Khan, Cybersecurity challenges of the Kingdom of Saudi Arabia: Past, Present and Future, Global Foundation for Cyber Studies and Research 2019, p. 7.

5 T. Nasarallah, Saudi Arabia: over 7 million cyberattacks foiled in 3 months, Gulf News, https://gulfnews.com/photos/lifestyle/ photos-fashion-abayas-by-safia-hussain-showcased-in-riyadh-1.1611420 228808? slide $=6$ [access: 16.04 .2021 ].

6 C. Kelly, IBM: Cyber breaches cost enterprises in the UAE and KSA over $\$ 6.5 \mathrm{~m}$ per attack in 2020, ITP, https://www.itp.net/news/93473-ibm- 
berattacks were registered ${ }^{7}$. The American Center for Strategic and International Studies reports that of all the attacks carried out between May 2006 and June 2020, 15 posed a significant threat to national security. In 2020, the Cybersecurity Exposure Index rankings on the degree of exposure to a cyberattack, and the Cyber Risk Index, which predict the possibility of experiencing it, Saudi Arabia ranked $31^{\text {st8 }}$ and 25-26, respectively ${ }^{9}$, places on a global scale.

At the beginning of the COVID-19 pandemic, in the first quarter of 2020, malware attacks (22\%) and spam (36\%) were recorded in the Middle East countries. It was a tough period for companies in Saudi Arabia in the process of converting to remote work ${ }^{10}$.

The emerging risk of loss of sensitive data sent by employees working from home resulted in a reorganization in the IT area across the country. The compulsory blockade to stop the virus spread has shifted all forms of communication to remote work, holding meetings at Zoom, online shopping, and maintaining virtual education. Until now, Saudi Arabia had a culture of working in the office and organizing

cyber-breaches-cost-enterprises-in-the-uae-and-ksa-over-65m-per-attack-in-2020 [access: 16.04.2021].

7 T. Nasarallah, op.cit.

8 J. Frisby, Cybersecurity Index (CEI) 2020, PasswordManagers.co, https://passwordmanagers.co/cybersecurity-exposure-index/ [access: 16.04.2021].

9 NordVPN, Cyber Risk Index, 2020, https://s1.nordcdn.com/nord/ misc/0.13.0/vpn/brand/NordVPN-cyber-risk-index-2020.pdf [access: 16.04.2021]. These cyberattacks have a severe impact on the economy at the financial, operational and tactical levels, with the potential to undermine citizens' confidence in government services and in power itself: A. Quadri, M.K. Khan, Cybersecurity challenges of the Kingdom of Saudi Arabia: Past, Present and Future, Global Foundation for Cyber Studies and Research 2019, p. 7.

10 A. Buller, Saudi Arabia sees cyber security boom as coronavirus bites, Computerweekly, 17.09.2020 [access: 16.04.2021]. 
personal meetings. Due to the dynamic change in virtually all companies' operating policies, there were calls for the rapid implementation of strategies that would enable employees to maintain productivity. It involved moving data to the clouds and granting access to remote IT resources of enterprises. As a result, it was necessary to increase the level of security in cyberspace by investing in new technologies by implementing security measures resistant to external attacks. Another important element was the training of employees ${ }^{11}$ who have access to company data to constantly analyze emerging threats and observe safety rules ${ }^{12}$.

More than half of the Chief Information Officers in Saudi Arabia see security management as the greatest and continuing technological challenge and consider investing in cybersecurity a key business goal. In addition, the need to maintain cybersecurity has become one of the main indicators of the performance of companies and digital transformation across the country, which will mean that spending on technologies will be higher and data leakage protection will be higher every year ${ }^{13}$.

\section{Attacks on the Cyberspace of Saudi Arabia}

One of the most dangerous attacks on the country's cyberspace took place in August 2012, when the Shamoon virus

11 A. Alzubaidi, Measuring the level of cyber-security awareness for cybercrime in Saudi Arabia, "Heliyon" 2021, vol. 7, no. 1.

12 A. Buller, Saudi Arabia sees cyber security boom as coronavirus bites, "Computerweekly", 17.09.2020 [access: 16.04.2021].

13 B. Wright, K. Allan, Saudi CIOs consider security their toughest tech challenge, CIO, 25.08.2020, https://www.cio.com/article/3445225/ saudi-arabias-cybersecurity-concerns-increase-as-threats-evolve.html [access: 18.04.2021]. 
was introduced into the internal communication network of the state-owned oil company Saudi Aramco. It aimed to stop oil and gas production and weaken the largest energy market company in the Middle East region. As a result of this incident, more than 30,000 computers were damaged, all data on their disks were deleted, and replaced with an image of a burning American flag. Saudi Aramco has been forced to halt work, block both e-mails from all employees, and access to the Internet to stop the spread of the virus. That put its operations on hold for two weeks and brought substantial financial losses. During the five-month Internet blockade, the cybersecurity team introduced measures to implement new cybersecurity solutions. The attack posed a threat to Saudi Arabia and Western countries dependent on oil supplies, particularly the US. Despite the lack of evidence, US intelligence accused Saudi Arabia's greatest rival in the region, Iran, of attacking and made known its suspicions that at least one Saudi Aramco employee was involved in the attack.

Another attack on Saudi Aramco, this time using the updated Shamoon 2 virus, took place in August 2017, and the company stopped working for 48 hours. A much shorter break in business operations resulted from the company's decision to constantly store backups made after 2012. According to the "New York Times", the purpose of the cyberattack was to trigger an explosion and generally sabotage the system ${ }^{14}$. Although it has not been confirmed who is responsible for the attack, Iran was accused anyway.

14 N. Perlroth, C. Krauss, A Cyberattack in Saudi Arabia Had a Deadly Goal. Experts Fear Another Try, “The New York Times”, https:// www.nytimes.com/2018/03/15/technology/saudi-arabia-hacks-cyberattacks.html [access: 16.04.2021]. 
In December 2019, Saudi government authorities detected a cyberattack planned on Saudi Arabia's critical infrastructure. The Dustman malware was to be used to carry it out, permanently deleting data stored on disks. It has not been informed which state authorities were to be targeted, but the fact that hackers left numerous traces on the network suggests its hasty organization. Importantly, it took place during the escalation of tensions on the Iranian-American line. According to CyberScoop, due to the political situation at that time, it is believed that Iranian hackers were behind them, based on the similarity of how the attacks were carried out and the traces left behind ${ }^{15}$.

Saudi Arabia, its government authorities, and businesses are not just targets of attacks that result in data deletion or blocking. In May 2020, the country fell victim to an unsuccessful espionage campaign led by the Iranian entity Chafer APT. It was to be carried out on critical Saudi infrastructure, particularly the telecommunications and tourism sectors that hold a significant amount of personal data, and the government administration to collect spy data, credentials, access to information, and possibly, deletion ${ }^{16}$.

In addition to the above, contemporary trends in Saudi Arabia indicate that cyber terrorists are using social media as an alternative to disrupt communication between citizens and hamper economic activity by penetrating user communi-

15 S. Lyngaas, Saudi cyber authority uncover new data-wiping malware, and experts suspect Iran is behind it, CyberScoop, https://www. cyberscoop.com/saudi-arabia-iran-cyberattack-soleimani/ [access: 17.04.2021].

16 B. Rusu, Iranian Chafer APT Targeted Air Transportation and Government in Kuwait and Saudi Arabia, Bitdefender, https://www.bitdefender.com/files/News/CaseStudies/study/332/Bitdefender-Whitepaper-Chafer-creat4491-en-EN-interactive.pdf [access: 17.04.2021]. 
cation channels. In addition, they use the network to recruit members, raise funds, or conduct disinformation attacks on Saudi Arabia. As many as 30.2 million citizens (91\% of the population) have access to the Internet, and 25 million have an account on a social network. Currently, the most frequently investigated media by terrorists are WhatsApp, YouTube, Facebook, Instagram, and Twitter ${ }^{17}$.

\section{Cybersecurity Strategy}

Due to the contemporary challenges for cybersecurity, the Royal Decree of October 31, 2017 established the National Cybersecurity Authority (NCA), whose main task is to increase the state's cybersecurity by preparing internal analyzes and legal solutions. The office is composed of: the Head of the State Security Presidium ${ }^{18}$, the Head of the General Intelligence Presidency (GIA), the Deputy Minister of Internal Affairs, and the Deputy Minister of Defense ${ }^{19}$. The NCA performs both regulatory and operational functions related to cybersecurity and works closely with public and private entities to improve the country's cybersecurity, protect its interests, national security, critical infrastructure, government services, and build a cyberspace environment to implement the 2030 strategy ${ }^{20}$.

17 Skillzme, Saudi Arabia Social Media Statistics 2018, https:// skillzme.com/ksa-social-media-statistics-2018 [access: 17.04.2021].

18 Presidency of State Security - is a Saudi security authority created in 2017 by creating supervision over the simultaneous actions of national anti-terrorist and intelligence services.

19 Saudi Gazette, King orders setting up of National Cyber Security Authority, https://saudigazette.com.sa/article/520782/SAUDI-ARABIA/King-orders-setting-up-of-National-Cyber-Security-Authority [access: 17.04.2021].

20 National Cybersecurity Authority, Essential Cybersecurity Con- 
The NCA has developed a strategic vision of cybersecurity that reflects Saudi Arabia's goals, creating conditions in cyberspace to maintain security, trust in authorities, and technological growth. The priority goals until 2030 include six aspects ${ }^{21}$ :

- Unification of cybersecurity throughout the country ensuring a high level of coordination and alignment, it is important to adopt a comprehensive national approach to cybersecurity by integrating and defining the national entities' roles and responsibilities to develop and implement regulations and policies, and comply with national standards.

- Risk management - identification of attacked elements in cyberspace and determination of damages. Then, verification of the most appropriate methods of risk elimination to reduce the negative effects.

- Optimal functioning in the cyberspace environment - introduction of comprehensive controls, national standards, and a compliance monitoring system that ensures the protection of the cybersecurity environment, including raising the level of social awareness of cyber threats.

- Dynamic Defense - strengthening and continuously developing national capabilities in the field of defense against cyber threats. Detection, prevention, response, and reorganization after attacks.

- International partnership - cybersecurity requires stable local and international partnerships, strengthened by advanced information exchange mechanisms. It allows systems to be refined and best practices shared.

trols, 2018, pp. 6-10.

21 National Cybersecurity Authority, National Cybersecurity Strategy (Overview), Kingdom of Saudi Arabia 2020, pp. 14-29. 
To achieve the required level of security, efforts should be made to strengthen the foreign partnership.

- Development in cyberspace - increasing national cybersecurity capabilities should be pursued. One of the main directions is an investment in education and training programmes and an investment in industry and research.

In addition to the above, due to the size of the Saudi economy, the Kingdom focused on creating governance structures that would allow to use the state's potential and counteract emerging challenges. Thus, in 2019 Saudi Arabia created another three bodies related to the NCA. Saudi Data and Artificial Intelligence Authority (SDAIA) aims to build one of the largest clouds in the region by connecting 83 data centers owned by over 40 government bodies. SDAIA has three key responsibilities: developing national data and artificial intelligence strategies; supervising their implementation; raising awareness in the field of data and AI, and informing about achievements in this field locally and globally (i.e., education and PR) and its subordinate National Center for Artificial Intelligence and Saudi Commission for Data and Artificial Intelligence. The actions are also a clear expression of the Kingdom's determination to expand its digital capabilities and build a future based on artificial intelligence and innovation. According to Saudi authorities, artificial intelligence will increase productivity, improve decision-making processes in all sectors, provide more innovative services to citizens and allow businesses to grow $^{22}$. It is also worth noting that Saudi Arabia is constantly updating the Cyber Crime Law of 2007.

22 A. Gernonimo, National Centre for AI to drive Saudi Arabia's digital future: minister, TahawulTech, 1.09.2019. 
In March 2021, Saudi Arabia's Ministry of Education and the National Cybersecurity Authority signed an agreement to launch joint cybersecurity training and research programmes. It is significant for investing in cybersecurity initiatives and a part of the implementation of the 2030 Strategy. The Ministry of Education and NCA are already implementing several joint projects on scholarships for cyberspace research and the development of higher education in cybersecurity ${ }^{23}$.

\section{Summary}

Since the first cyberattack on Saudi Aramco, Saudi Arabia has introduced several measures to reduce their incidence. One is the government's decision to double the cybersecurity budget. In 2012, these expenses increased from USD 7.8 billion to USD 15.4 billion $^{24}$, while in 2020 , they reached USD 27.2 billion $^{25}$. In 2014, the National Center for Cybersecurity Technology was established, a research and development institution dealing with security, network, software, and information security issues. The analyzes prepared by the Center are to prepare you for the implementation of the "Vision 2030" project.

23 Arab News, Deal signed to boost cybersecurity education in Saudi Arabia, https://www.arabnews.com/node/1830711/saudi-arabia [access: 17.04.2021].

24 S. Alshathry, Cyber Attack on Saudi Aramco, "International Journal of Management and Information Technology" 2017, vol. 11, no. 5, p. 3039.

25 USSABC Economic Brief: Saudi Arabia's Emergence in Cyber Technology, U.S.-Saudi Arabian Business Council, http://ussaudi.org/wp-content/uploads/2020/01/Economic-Brief-Saudi-Cybersecurity-Leadership. pdf [access: 17.04.2021]. 
The state cooperates in cybersecurity both with international organizations (e.g., the United Nations, the League of Arab States) and based on bilateral agreements (e.g., the United States, the United Kingdom, the United Arab Emirates). However, due to tensions with an increase in the number of cyberattacks, he is most active in the Gulf Cooperation Council, where he initiates talks on extending cooperation in cybersecurity. The number of actors Saudi Arabia cooperates with is limited as the state does not see cybersecurity as a priority of its foreign policy but rather as an issue of internal security ${ }^{26}$.

The global ambitions of Saudi Arabia are to be expressed by the planned organization of the international technology event LEAP 2021. The conference "will catalyze a monumental digital transformation in every sector of Saudi Arabia's industry and business", and LEAP is to be a manifestation of the kingdom's goal of seizing positioned at the forefront of emerging technologies.

Other PR activities of the Saudis also have a global reach. Saudi Arabia is the first country to grant robot citizenship (whatever that means). It is about Sophia, the famous Hong Kong-designed Hanson Robotics robot that "picked up her passport” in 2017.

\section{Bibliography}

Alshathry S., Cyber Attack on Saudi Aramco, "International Journal of Management and Information Technology" 2017, vol. 11, no. 5 .

26 Saudi Arabia's Foreign Policy Priorities, Chatham House, https:// chathamhouse.soutron.net/Portal/DownloadI mageFile.ashx?objectId=3483 [access: 17.04.2021]. 
Alzubaidi, Measuring the level of cyber-security awareness for cybercrime in Saudi Arabia, "Heliyon" 2021, vol. 7, no. 1.

Arab News, Deal signed to boost cybersecurity education in Saudi Arabia, https://www.arabnews.com/node/1830 711/saudi-arabia.

Buller, Saudi Arabia sees cyber security boom as coronavirus bites, "Computerweekly", 17.09.2020.

Frisby J., Cybersecurity Index (CEI) 2020, PasswordManagers.co, https://passwordmanagers.co/cybersecurityexposure-index/.

Gernonimo, National Centre for AI to drive Saudi Arabia's digital future: minister, TahawulTech [access: 1.09.2019]. Hathaway M., Spidalieri F., Alsowailm F., Kingdom of Saudi Arabia cyber readiness at a glance, Potomac Institute for Policy Studies 2017.

Kelly, IBM: Cyber breaches cost enterprises in the UAE and KSA over $\$ 6.5$ m per attack in 2020, ITP, https://www.itp. net/news/93473-ibm-cyber-breaches-cost-enterprisesin-the-uae-and-ksa-over-65m-per-attack-in-2020.

Kingdom of Saudi Arabia, Saudi Vision 2030, Riyadh 2016.

Lyngaas S., Saudi cyber authority uncover new data-wiping malware, and experts suspect Iran is behind it, CyberScoop, https://www.cyberscoop.com/saudi-arabia-irancyberattack-soleimani/.

Nasarallah T., Saudi Arabia: over 7 million cyberattacks foiled in 3 months, "Gulf News", https://gulfnews.com/ photos/lifestyle/photos-fashion-abayas-by-safia-hussainshowcased-in-riyadh-1.1611420228808? slide $=6$.

National Cybersecurity Authority, Essential Cybersecurity Controls, 2018. 
National Cybersecurity Authority, National Cybersecurity Strategy (Overview), Kingdom of Saudi Arabia 2020.

NordVPN, Cyber Risk Index, 2020, https://s1.nordcdn.com/ nord/misc/0.13.0/vpn/brand/NordVPN-cyber-risk-index-2020.pdf.

Perlroth N., Krauss C., A Cyberattack in Saudi Arabia Had a Deadly Goal. Experts Fear Another Try, "New York Times", https://www.nytimes.com/2018/03/15/technology/saudi-arabia-hacks-cyberattacks.html.

Rusu, Iranian Chafer APT Targeted Air Transportation and Government in Kuwait and Saudi Arabia, Bitdefender, https://www.bitdefender.com/files/News/CaseStudies/ study/332/Bitdefender-Whitepaper-Chafer-creat4491en-EN-interactive.pdf.

Saudi Arabia's Foreign Policy Priorities, Chatham House, https://chathamhouse.soutron.net/Portal/DownloadImageFile. ash $x$ ?objectId $=3483$.

Saudi Gazette, King orders setting up of National Cyber Security Authority, https://saudigazette.com.sa/article/520782/SAUDI-ARABIA/King-orders-setting-upof-National-Cyber-Security-Authority.

Quadri M., Khan K., Cybersecurity challenges of the Kingdom of Saudi Arabia: Past, Present and Future, Global Foundation for Cyber Studies and Research 2019.

Skillzme, Saudi Arabia Social Media Statistics 2018, https:// skillzme.com/ksa-social-media-statistics-2018.

USSABC Economic Brief: Saudi Arabia's Emergence in Cyber Technology, U.S.-Saudi Arabian Business Council, http:// ussaudi.org/wp-content/uploads/2020/01/EconomicBrief-Saudi-Cybersecurity-Leadership.pdf.

Wright K.A., Saudi CIOs consider security their toughest tech challenge, CIO, 25.08.2020, https://www.cio.com/ 
article/3445225/saudi-arabias-cybersecurity-concernsincrease-as-threats-evolve.html.

\begin{abstract}
The technological development in Saudi Arabia comes with risks, but it also provides an opportunity to create a robust cybersecurity environment based on world-class patterns. Saudi Arabia's 2020 budget allocates 102 billion rials ( $\$ 27.2$ billion) to security and regional administration, including cybersecurity. The size of Saudi Arabia's cybersecurity market in 2019 was 10.9 billion rials ( $\$ 2.9$ billion) and is expected to grow by $16.59 \%$. by 2023 - to an estimated value of 21 billion rials ( $\$ 5.6$ billion).

The government has increased investment in digital infrastructure and has also established development and training programmes for Saudi Arabian citizens and modernized information security management. In 2018, the Saudi Federation of Cyber Security, Programming and Drones (SAFCSP) was created to stimulate technological innovation and provide professional development to Saudi Arabian citizens.

These activities are gaining recognition around the world. The Kingdom was recently recognized by the International Telecommunications Union (ITU) as a cybersecurity leader in its region and a reformer in building its capacity: Saudi Arabia jumped to $13^{\text {th }}$ place in the 2019 ITU Global Cybersecurity Index from $46^{\text {th }}$ (2017).
\end{abstract}

Keywords: Saudi Arabia, cybersecurity, cyberspace, law

\begin{abstract}
Abstrakt
Technologiczny rozwój Arabii Saudyjskiej wiąże się z wieloma ryzykami, ale z drugiej strony stwarza okazję do zaprojektowania solidnych fundamentów cyberbezpieczeństwa, zgodnych z najwyższymi standardami na świecie. Budżet tego państwa na 2020 r. przewidywał 102 miliony riali (27,2 mln dolarów amerykańskich) na rozwój bezpieczeństwa i administracji regionalnej, w tym cyberbezpieczeństwa. Wartość saudyjskiego rynku cyberbezpieczeństwa w 2019 r. szaco-
\end{abstract}


wano na 10,9 mln riali (2,9 mln USD) i spodziewany jest jej wzrost o $16,59 \%$ do 2023 r. Szacuje się, że w tym czasie rynek cyberbezpieczeństwa warty będzie $21 \mathrm{mln}$ riali (5,6 $\mathrm{mln}$ USD).

Rząd Arabii Saudyjskiej zwiększył wydatki na infrastrukturę cyfrową i modernizację zarządzania bezpieczeństwem informacyjnym oraz stworzył programy rozwojowe i szkoleniowe dla swoich obywateli. W 2018 r. powstała Saudyjska Federacja Cyberbezpieczeństwa, Dronów i Programowania (ang. the Saudi Federation of Cyber Security, Programming and Drones, SAFCSP), aby stymulować powstawanie innowacji technologicznych i stworzyć możliwości rozwoju zawodowego dla obywateli Arabii Saudyjskiej.

Wskazane działania spotkały się uznaniem całego świata, a Międzynarodowy Związek Telekomunikacyjny (ITU) nadał Arabii Saudyjskiej miano regionalnego reformatora i lidera w zakresie cyberbezpieczeństwa. Tym samym znalazła się na 13 miejscu (w 2017 r. zajmowała 46.) prowadzonego przez ITU wskaźnika Global Cybersecurity Index.

Słowa kluczowe: Arabia Saudyjska, cyberbezpieczeństwo, cyberprzestrzeń, prawo 


\section{Edyta Wolny-Abouelwafa}

Polish Academy of Sciences

ORCID ID: https://orcid.org/0000-0003-4645-8909

\section{Representations of Egyptian Society in Egyptian Patriotic Video Clips (2018-2020)}

For the modes of music are never disturbed without unsettling the most fundamental political

and social conventions

Plato, The Republic, 242 $\mathrm{c}^{1}$

\section{Introduction}

Media play a significant role in people's lives. They can influence how society thinks - change current thinking or even create a new one. Media can show the 'reality' of other cultures or countries far from us and let us understand them as the transmitter intends. The author of the article calls this 'outside vision'. We can also talk about the messages which media send about society to this particular society. That is what she calls 'inside vision. This kind of vision is the main object of research, which fragmentary results are presented in the paper.

1 Greek Texts E Translations. Plato, Republic (English). Pl. Resp. $424 d$, perseus.uchicago.edu, http://perseus.uchicago.edu/perseus-cgi/ citequery3.pl .dbname $=$ GreekTexts \&getid $=1 \&$ query $=$ Pl. $\% 20$ Resp. $\% 20$ 424d [access: 18.01.2020]. 
The first and fundamental role of music is helping people relax - they can listen to it and forget about their problems, dance to it, meditate, etc. Music can be treated as a basic thing in somebody's life - his hobby - and can exist as a background to other activities. In both cases - whether we want it or not - its messages reach the listener.

While talking about the patriotic songs of any country, we cannot forget about their political connections. The political function of music is nothing new. Maciej Białas notes that there can be featured three main social communication situations in which music plays a part ${ }^{2}$. One of them ${ }^{3}$ is the situation of political instrumentalization of the music, in which "music is used to define and expose outlooks, ideological and political attitudes (...)"4.

In the author's opinion, the video clips accompanying songs (especially patriotic ones as their message is much more important for the society and country than any other kind of song) are key because the authors influence the recipients by using more senses. Not only using the sense of hearing but also of vision. Bartosz Wypych seems to think similarly, and while featuring the communication codes (in the case of music they are: music, word, and image), he mentions: “(...) code which can influence most effectively in the political way, is the word code, then image and in the end - music"5.

2 M. Białas, O specyfice muzyki politycznej, [in:] Sztuka i Polityka. Muzyka popularna, eds. M. Jeziński, Ł. Wojtkowski, Toruń 2012, pp. 11-12.

3 Others are: the situation of communing with the music and the situation of fun with music.

4 M. Białas, op.cit., p. 12; all translations from Polish, Arabic and Egyptian dialect to English in this article are made by the author.

5 B. Wypych, O nieintencjonalności w muzyce popularnej, [in:] Sztuka i Polityka. Muzyka popularna, eds. M. Jeziński, Ł. Wojtkowski, Toruń 2012, p. 57. 


\section{Patriotic Songs in Egypt}

It has to be noted that patriotic (national) ${ }^{6}$ songs in all their forms are almost constantly present in Egypt - the most populous country in the Middle East and Arab countries ${ }^{7}$. We do not only deal with turgid, solemn cantos supported by brass bands. While talking about Egyptian patriotic songs (and the word 'song' is used intentionally), we have to remember that we will be able to analyze all manner of genres of music. There are slow, heart-rending melodies and, on the other hand, lively, cheerful rhythms that are representative of pop music or folklore. They can be heard during official ceremonies or events which the President of the Arab Republic of Egypt and the representatives of the Egyptian government attend; during 'normal' concerts by more or less popular Egyptian (or generally - Arab) stars; in coffee shops, but also during weddings and small or large family celebrations. An interesting example from true life can be presented here. Well, the author, during her research stay in Egypt in 2013-2014, while doing some shopping in the vegetable market, saw a groom with some members of his family and a musical group arriving in front of a beauty salon, waiting for his bride. All this time, the group was playing some typical wedding songs. Suddenly, they started playing (a very popular at that time) patriotic song (entitled:

6 These two expressions are used interchangeably by the author of the article.

7 At the time of finishing writing the article it was more than 100 million Egyptians; source: Al-Ğihāz al-markazì li-l-ta‘bi’a al-‘āmma wa-ihṣā, Central Agency for Public Mobilization and Statistics, https://www. capmas.gov.eg/ [access: 18.01.2020]. 
Tislam il-ayādi $\bar{l})^{8}$. The author was surprised as almost everybody left their activities, started to dance, sing and have fun. It was clear that the song was not just well-known by everybody but also beloved by most.

Egyptian patriotic songs are created by the famous (or hoping to be famous) Egyptian artists ${ }^{9}$ but also by Arabic stars, as, e.g., Emiratian Husayn al-Ğasmī and the Lebanese Nancy Ağram. This popularity works in both ways - some artists stay popular thanks to releasing the song for beloved Egypt, and for others, it can be a way of holding on to current popularity. Of course, suppose their song is also connected with the country's politics. In that case, they can be used even more while presenting the activities of the government on television - which also increases its presence in the media and awareness among the people.

It is easy to conclude that if such songs are available all the time, in the difficult (e.g., terrorist attacks) or important (e.g., during national festivals or elections) moments for the country, their frequency is higher.

As mentioned, patriotic songs are available everywhere, but mainly they are transmitted on radio, television, and now - the Internet. For them to be 'everywhere', it is important to underline the first two mediums as they let people hear the new rhythms in the coffee shops, cars while commuting to and from work, in shops, homes, etc.

8 All the names originally from Arabic or Egyptian dialect were written in the article according to ISO (International Standardization Organization) rules.

9 This is nothing new. We cannot forget that huge Egyptian names in history well-known in the whole Arab world such as 'Abd al-Halim Hāfiz or Umm Kultūm also demonstrated for fans songs showing their love for their homeland. 


\section{The Role of Egyptian Radio and Television in Strengthening Patriotic Feelings}

The command of patriotic songs (and their possible effect on society) is not surprising as they often are present on the radio and television. Of course, nowadays, we can also hear them on the Internet. These two mediums have been important for delivering patriotic messages from their early beginnings. The radio has existed in Egypt since the 1920s, from the time of issuing a royal decree allowing the establishment of local radio stations. The most important day is May 31, 1934, when the national Egyptian Radio station was established ${ }^{10}$. For the research material, the time after the Second World War is significant. As we can read on the Egyptian website - State Information Service: “(...) the role of the radio at this stage was to draw and report the real values of the Egyptian personality ${ }^{11}$ from all aspects: economic, political and social (...)"12. In his article, Zein Nassar notes that: "Lyricists were implored to present nationalistic songs or songs characterized by Egyptian style and spirit,

10 Z. Nassar, A History of Music and Singing on Egyptian Radio and Television, [in:] Music and Media in the Arab World, ed. M. Frishkopt, Cairo, New York 2010, pp. 67-68.

11 The underlining here has been made by the author to focus attention on the quoted words.

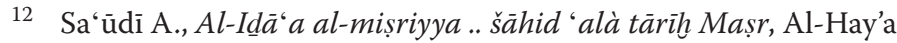
al-‘āmma li-l-isti'lāmāt. State Information Service, https://www.sis.gov. eg/Story/182829/\%D8\%A7\%D9\%84\%D8\%A5\%D8\%B0\%D8\%A7\%D8\%B 9\%D8\%A9-\%D8\%A7\%D9\%84\%D9\%85\%D8\%B5\%D8\%B1\%D9\%8A\%D8 \%A9-..-\%D8\%B4\%D8\%A7\%D9\%87\%D8\%AF-\%D8\%B9\%D9\%84\%D9\%89-\%D8\%AA\%D8\%A7\%D8\%B1\%D9\%8A\%D8\%AE-\%D9\%85\%D8\%B5\%D8\% B1?lang=ar [access: 18.01.2020]. 
taking up Egyptian topics such as cotton and the daily life of peasants and workers" 13 .

The role of the radio can be summarized by using again words from the official Egyptian website: "The Egyptian Radio ... is the national radio and pioneering in the whole region. It stayed the cultural and lightning lantern from the time of its establishment in 1934 until now. It has played a national role and presented the giants of thought and stars in all fields. It was the voice of the Egyptian people, taking part in the treatment of its issues and problems and expressing its hopes and inspirations"14. It happens the same even today but on a larger scale.

In 1960 Egyptian Television was established ${ }^{15}$. As mentioned, Nassar in 2010 underlined: "Egyptian state television (...) is still considered an important means of presenting different kinds of songs, including via concerts and video clips" ${ }^{16}$. Now, in 2021, it can be confirmed that it still happens, not only on Egyptian state television but on many TV channels, even private ones. So we observe the same mechanism which had worked at the time of establishing radio, but on a much larger scale, as there are greater possibilities of influencing - not only through the radio and television but also through the Internet or - please note! - ringtones and melodies on mobile phones.

13 Z. Nassar, op.cit., p. 70 [as cited in: M. Fathy, al-Idha' a al-misriya fi nafs qarn, 1934-1984, Cairo 1984].

14 Sa'ūdì A., op.cit.

15 Z. Nassar, op.cit., p. 72.

16 Ibidem, p. 75. 


\section{The Research Material and Research Questions}

The research material presented in this article consists of three video clips relating to the patriotic songs released in the years 2018 and 2020. Both songs released in 2018 have the same title - Tahya Masr ("Long live Egypt") and the third one (from 2020) - Al-Aṣl mașrī ("The Origin is Egyptian") ${ }^{17}$ and represent three different kinds of songs from a musical point of view ${ }^{18}$.

The video clips can not be studied without a deep analysis of the lyrics. Thus, only a few will be presented to discover the most important information connected with video clips. Of course, the opposite situation - concentrating only on the verbal message itself can be sufficient. However, in these cultural texts (video clips), the analysis without knowing the message sent via lyrics will not be complete because the videos are mainly the background of the transmitted content. Sometimes they add some message and create a particular vision - very often strengthening the verbal message.

Two main research questions can be asked:

1) How can the Egyptian society presented in the video clips be described?

17 Ug̉niyyat "Tahyā Maṣr" ġinā' Madhat Șāliḥ wa-Rihām 'Abd al-Hakìm wa-May Fārūq, Youtube, https://www.youtube.com/watch?v=raib33q7VU4 [access: 18.01.2020)], Ug̉niyyat Tahyā Maṣr li-Aḥmad Š̄ba, Youtube, https://www.youtube.com/watch?v=LxfbOvH8zjg\&list=RDLxfbOvH8zjg\&start_radio=1 [access: 18.01.2020)]; Wi ramadān 2020 / Tāmir Husnī \# Al-Aṣl_maṣrī, YouTube, https://www.youtube.com/ watch?v=HLnkVkrsvxM [access: 18.01.2020].

18 The author of the article will not analyse the songs according to the science of music as she has no competencies to do it. She just mentions the observation made by a simple receiver not a specialist. 
2) Is the image of a society fully compatible with reality?

The word 'fully' needs to be underlined here. One can immediately assume that because it is the art presented to the Egyptian society - this real one - so its vision shown in the video clips cannot be completely detached from reality. But how much does this vision reflect reality, and how much does it try to create it? This issue is essential.

\section{The Analysis of the Research Material}

The first song entitled Tahya Masr ("Long live Egypt"), sung by Madhat Șāliḥ, Rihām 'Abd al-Hakīm and May Fārūq, is probably the only one presented in the article that can be immediately associated with the 'patriotic' one as we imagine it because of its military style. It starts with an appeal to a citizen of Egypt for him to build history from the beginning. Egyptians built the land, and they are not worried about blood. Finally, 'the children of Egypt' (i.e., citizens of Egypt) are always ready to protect the country. The unity of the citizens is underlined in the song. Here, one can observe a prevalent motif in patriotic songs - 'id wāhda', i.e., "one hand”. The Nile river is also the factor uniting all of them. We can hear that Egypt is seven thousand years old and that the love for the army flows in the veins of Egyptians. These lyrics are significant: "His grandfather wrote on an obelisk that to build Egypt [we have to work] hand in hand"19. The message is clear - the Ancients already knew that the success of Egypt is its citizens cooperating for its well-being. The role of the Egyptian army is also emphasized in lyrics. They are brave heroes.

19 Uǵniyyat "Tahyā Maṣr" ginā’ Madhat Șāliḥ wa-Rihām 'Abd al-Hakìm wa-May Fārūq, op.cit. 
And together - the people, army, and police will eradicate all the difficulties. The building of Egypt come from the nation's will. And this will is "from the iron" ${ }^{20}$. History is a witness that they know how to build, and the future will prove it. The Egyptian is also an aware person and knows adversity and what is going on around him.

To sum up, this song does not talk about the country itself but its citizens. They are heroes here. It highlights the bravery of the Egyptian army in the first place and second every Egyptian citizen. The connection between army and nation is important here. The song shows pride in being Egyptian, a hero of homeland and history, which the whole world should appreciate. It is a kind of song which can be suitable for a more difficult time, e.g., time of anxiety.

The video clip starts by showing the Egyptian flag - perhaps to create a feeling of bombast. Then there are different snapshots, and they show, e.g., Ancient decorations and other historical threads (mainly Pharaonic ones - but we can also see President Anwar As-Sādāt ${ }^{21}$ - or moment from the opening of the second line of the Suez $\mathrm{Canal}^{22}$ ), the exercises and parades of the Egyptian soldiers, citizens waving the Egyptian flag, tourists, Egyptian workers, doctors. The current president of the country - 'Abd al-Fattāh as-Sìsī, sportsmen (and crazy and happy tribunes), the Grand Imam of Al-Azhar (the highest representative of Islam in Egypt)

20 Ibidem.

21 President of Egypt from 1970 till his death in 1981.

22 It happened in 2015; to discover more, see: E. Wolny-Abouelwafa, Pride in History - Particularly Pharaonic - in Contemporary Egyptian Songs as part of Shaping National Identity, [in:] EGYPT YESTERDAY AND TODAY. Between Tradition and Modernity, eds. K. Myśliwiec, K. Pachniak, K. Nabożna, E. Wolny-Abouelwafa, Warsaw 2019, p. 74. 
hugging Pope Francis (the head of the Catholic Church) are also shown.

Generally, there are many references to Islam and Christianity - the two main religions available in Egypt. The Quran, crosses, and the interiors of the churches and mosques are presented. While mentioning the 'id wähda motif', one can see mainly the cross and the Quran shown together or close to each other.

When the artists sing about the threat, the military groups of the terrorist organization ISIS are shown as a symbol of evil that must be resisted. Their opposites are brave Egyptian soldiers.

In all video clips mentioned in this article, what can be observed is the smile on the Egyptian faces - the basic element of the videos ('smile motif'). The other common element are children ('children motif'). Of course, mainly they smile, many times they observe the flag, some wear army clothes.

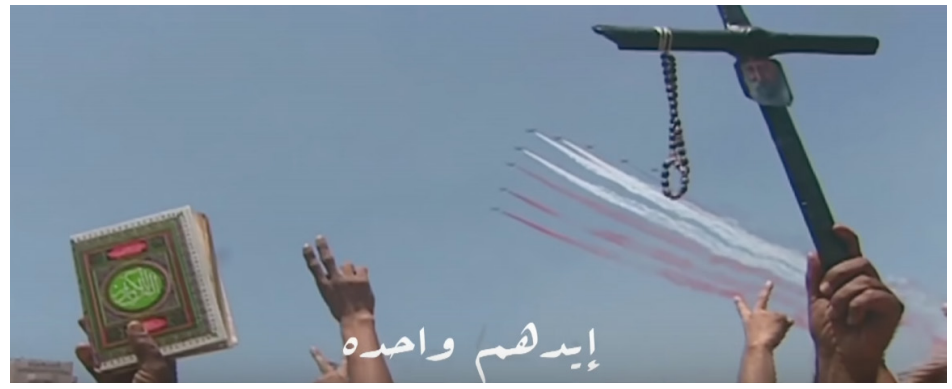

Fig. 1 Screenshot from the song Tahya Masr presenting ' $i d$ wähda motif' by showing together the Quran, cross and rosary and Egyptians' fingers in the sign for victory. In the background, Egyptian army planes 'draw' on the sky the Egyptian flag. Captured by the author ${ }^{23}$

23 Ug̉niyyat "Tahyā Mașr" gināa' Madhat Ṣālih wa-Rihām 'Abd al-Hakìm wa-May Fārūq, op.cit. 
The second Tahya Masr song is representative of ša'bi music ${ }^{24}$ and was released in connection with the presidential elections ${ }^{25}$. With the song, the singer (Ahmad Šiba) expresses his love of country and highlights his uniqueness, full tolerance. He loves "its smile" (remember the 'smile motif' mentioned above!). With the sentiment, he sings about the special Egyptian atmosphere of gathering together. For him, Egypt is the most beautiful thing in the world, and simply the whole world is close to it. He proudly uses a popular Egyptian expression: Masr Umm id-dunya, which means "Egypt is the mother of the world".

For him, the army are eagles protecting the borders. From a scientific point of view, this comparison is interesting as many other patriotic songs compare soldiers to lions. He sings that soldiers do not sleep day or night ${ }^{26}$, and their only one goal is the security of the country and people.

Šiba underlines that Egypt was mentioned in the Quran and other religions. It also has a long history, prestige, special enthusiasm, and then with the help of the hands of Egyptians will the wealth for Egypt and export be created.

Its video clip presents representatives of the people from all Egypt - citizens from its north and south, people having different colors of skin, fishermen, people driving tuk-tuks, very local districts and very modern ones, young people and older ones, children, men and women in different clothes -

24 Special kind of folk music, very popular in Egypt; to discover more, see e.g. What is Shaabi?, http://www.aswandancers.org, http:// www.aswandancers.org/shaabi-history [access: 18.01.2020].

25 The presidential elections took place in 2018 and the victor was again 'Abd al-Fattāh as-Sīsī.

26 This information can also be found in other Egyptian patriotic songs. 
more covered and those wearing clothes the same as their European neighbors, Christians, and Muslims, representative of all the social groups of Egypt. All of them are happy. Many of them wave Egyptian flags, they dance. We can also see the army and police - some of them with a smile on their faces helping citizens. The soldiers are presented in the desert, sky, and on the sea. Again, the message is clear and, without a doubt, about a strong army and police protecting the country. We can also observe some people wearing TShirts encouraging voting or others who have already voted (we can understand it because we see the print on their fingers, and this is a mark which voting Egyptian receive).

As in the mentioned video clip, we can see the crowds on the tribunes or the national teams of different sports. The figure of the president is also mentioned here. 'Abd al-Fattāh as-Sīsī is presented alone or with leaders of other countries.

Traditionally, references to Islam, Christianity, and Pharaonic Egypt are available. It should be highlighted that in this video, we can see disabled citizens. It is important as even a few years ago, the topic of disability was kind of taboo. It has changed under the rule of president 'Abd al-Fattāh as-Sīsī who, with many activities, tries to "include" the disabled into society. He even called 2018 the Year of Persons with Disabilities ${ }^{27}$. It proves that his moves reflect the video clips to the patriotic song and send one clear message compatible with the Egyptian authorities - Egypt is a homeland for every person, rich or poor, sick or in good health, man or woman,

272018 year of Persons with disabilities, Al-Hay'a al-‘āmma li1-isti 'lāmāt. State Information Service, https://www.sis.gov.eg/Story/142865/2018-year-of-Persons-with-disabilities?lang=en-us [access: 18.01.2020]. 
adult or child. Every one ${ }^{28}$ of them is a full Egyptian citizen, and all of them will look cheerfully and with hope to the future, are proud of their country, and together, they will create and build it.

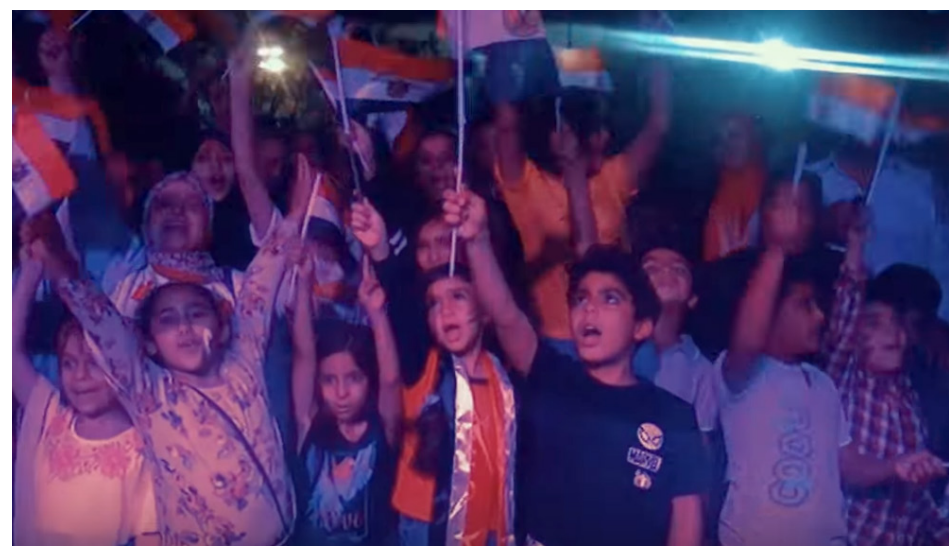

Fig. 2 Screenshot from the second analyzed song Tahya Masr presenting Egyptian children waving Egyptian flags. Captured by the author ${ }^{29}$

The last song, released in 2020 and sung by an Egyptian star famous in the whole Arab world, Tamer Hosny (Tāmir Husnī), Al-Aṣl mașrī was a kind of advertisement made by WE company with the cooperation of the Ministry of Social Solidarity and a few banks and social organizations.

This piece represents the category of Egyptian patriotic songs, which the author has called 'patriotic songs to comfort hearts during the COVID-19 pandemic' - explanation is here superfluous. As we can observe, the threat which

28 Underscore is made by the author to emphasize these words.

29 Ug̉niyyat Tahyā Maṣr li-Aḥmad Šìba, op.cit. 
caused the existence of this kind of song is different than it appeared earlier (external or internal problems of the country) and found its reflection in patriotic music.

As can be expected in such world-conditions, the song is dedicated to supporting Egyptians in the time of pandemic and here exactly in ramadān ${ }^{30}$, which is a special month when Egyptian families gather and spend much time together. It was impossible, of course, in the time of the COVID-19 pandemic.

The singer addresses his words to the Egyptian and reminds him about his roots and that all Egyptians are wonderful and immediately awake to commitments. He tries to reassure him that they are finally together and hand in hand ('i $d w \bar{a} h d a$ motif') on one boat that they will handle against all difficulties. He shows his pride and appreciation to his cocitizens and country, which calls, of course, Umm id-dunya.

The video clip message is straightforward and easy to understand. Tamer Hosny with a group of musicians stands on the boat sailing from the south of Egypt to Cairo. On its way, other boats with Egyptians join them and, step by step, are more densely packed. Starting the trip from the South of Egypt was undoubtedly intentional - there is thinking which says that these 'real Egyptians' from father and grandfather (Pharaoh, one would say) were the inhabitants of the

30 Ramaḍan is the ninth month of the Islamic lunar calendar which consists of twelve months, each of them having 29 or 30 days. During this month, Muslims must abstain from food, drink and sexual relations from sunrise to sunset. This month is unique not only because its cultural meaning in the Arab world but also in pop culture and media. That is why creating special advertisements (even longer than normal) which can be songs sung by popular actors or singers, as here presented, is one of the symptoms of an every year even higher influence of 'ramaḍan atmophere' on Arab (and Egyptian) pop culture. 
South. Exactly when he sings about roots and origin - we can see in the video mainly the people from Upper Egypt.

Observing the Egyptian society shown in the clip, we can see older men and women (some of them cover hair, others not) - all of them smiling ('smile motif'), cheerful children ('children motif'), representatives of the whole nation: people coming from all over the country - Aswan, south of Egypt, central Egypt and the north, people having different color skin, different ages. All of them wave kindly to each other and, together, hand in hand, keep on sailing. Again, as in the previous art, we can also observe disabled citizens.

When the boats arrive at Cairo, there are also representatives of different professions, for example, doctors or engineers.

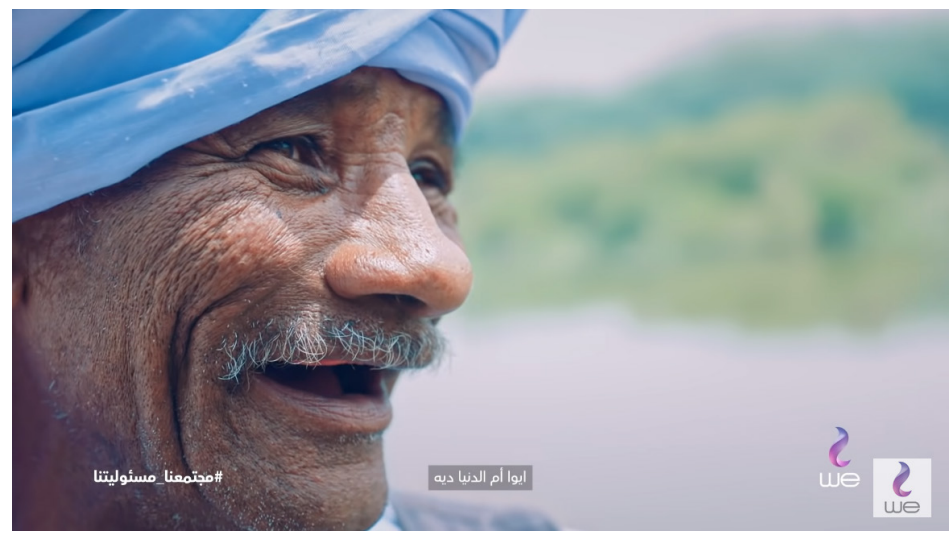

Fig. 3 Screenshot from the song Al-Aṣl mașrī presenting 'smile motif.' Captured by the author ${ }^{31}$

At the end of the video clip, where all of them arrive in Cairo, the boats are very close to each other - this also has

31 Wì ramadān 2020 / Tãmir Husnī \# Al-Așl_mașrī, op.cit. 
symbolic meaning. After the music finishes, the viewers can hear the words supporting and uniting the society and the promise that together, they will overcome the difficulties. Very meaningful, and matching the situation - the pandemic - and the message of the song is as well hashtag available all the time on the screen: 'مجتمعنا_مسئوليتنا' which means: "our society is our responsibility". Except for the pandemic, these words can represent perfectly all the patriotic songs and most of their video clips.

\section{Conclusions}

The analysis of these three video clips shows that the Egyptian society presented in all of them is pretty similar. All the clips show people who look at the future with a smile on their faces. They are together, and together they will build this future because just thinking of the cooperation, they can succeed. They all are proud of their homeland. Maybe they are different from each other - in terms of origin, gender, approach to tradition or religion, or generally they can have different religions, their economic status can be different, and they can live in different places and conditions, some of them are full of power, some can be sick. But all of them have Egyptian roots. They have another common thing - the centuries history, as taught in Egypt - 7000 years. Most of the patriotic video clips (or video clips relating to patriotic songs - these terms are used interchangeably by the author) highlight the role of the army, respect for soldiers, and the strong connection between army and nation. Here we arrive at the next important issue - all these Egyptians will overcome all difficulties, fight against 
all internal and external threats or even the pandemic. Here one would like to add: and they will live happily ever after... (and build Egypt stronger and stronger, happier and better). They will be forever proud of Egypt - from its history or from what they will create. After all, their grandparents (Pharaohs) left a great legacy, heritage, so this is waiting for new generations to do. That is what they expect to do, and the whole world will appreciate it as well. It is the answer to the first research question - this is the description of the Egyptian society coming from the analyzed video clips.

The answer to the second question - if the image of the society is fully compatible with reality - is now expected. Partly - yes, because there is a tendency from the last few years that the videos show the diversity of the society. Not only because of the religions but many different things, as mentioned before. Except for these differences, they can unite. Egyptians differ in unity.

Still, the image presented in the videos is idealized - less or more, it depends on which part of the movie we will exactly compare with the reality. It is not surprising. Actually, it is expected. It would be bizarre if the songs (or their videos) created to reassure Egyptian hearts would mention one by one all problems in the country or the world. There are many possible reasons for idealizing particular parts of the videos, but they are not a subject for the article. That is why there will not be a deliberation about them here. Without any doubt, it can be said that the videos present the ideal which would be the best if the citizens pursued it in everyday life. To create a cooperating nation full of happiness, hope, love for each other, and power to grow the beloved country. 


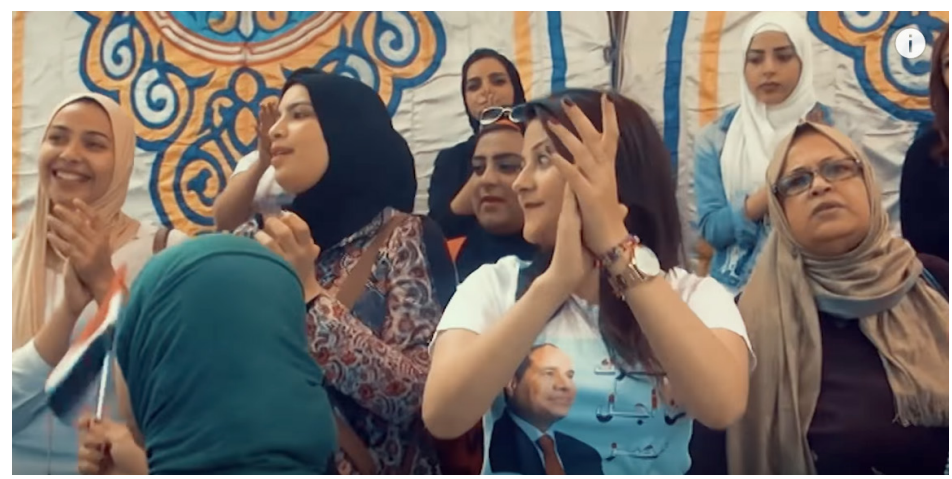

Fig. 4 Screenshot from the second song Tahya Masr is presenting dancing Egyptian women. Captured by the author ${ }^{32}$

\section{Summary}

One can say that the patriotic songs are performed by different artists and represent different kinds of music which can mean that they can be addressed to different Egyptian recipients. The first one - maybe to older members of society, more attached to the army lovers, the second to younger and those who love ša 'bì music. The third can be addressed to all Egyptians who miss the atmosphere of gathering and who wish to spend ramaḍan in a typical way, not 'closed' at home because of the pandemic and scared about the health and lives of their beloved ones and scared for future.

They were created at a similar time - two in 2018 and one in 2020. All of them and their video clips send similar messages - pride in country and co-citizens, support for every Egyptian and their army, trust in their strength in unity, willingness to build the next important thing for the country, world, and history, and a positive outlook on the future.

32 Ug̉niyyat Tahyā Maṣr li-Aḥmad Šìba, op.cit. 
The video clips do not fully capture the real Egyptian society - some things are similar, but the image is more idealized and is more the expected one than one hundred percent the same.

\section{Bibliography}

Al-Ğihāz al-markazì li-l-ta 'bi'a al- 'āmma wa-ihșāa, Central Agency for Public Mobilization and Statistics, https:// www.capmas.gov.eg/.

Bassiouni M.Ch., Chronicles of the Egyptian Revolution and its Aftermath: 2011-2016, n.p. 2017.

Białas M., O specyfice muzyki politycznej, [in:] Sztuka i Polityka. Muzyka popularna, eds. M. Jeziński, Ł. Wojtkowski, Toruń 2012.

Greek Texts E Translations. Plato, Republic (English). Pl. Resp. 424d, perseus.uchicago.edu, http://perseus.uchicago.edu/perseus-cgi/citequery3.pl?dbname=GreekTex ts\&getid=1\&query=Pl.\%20Resp.\%20424d.

Jeziński M., Muzyka popularna i jej odbiorcy w poszukiwaniu autorytetu, Toruń 2017.

Nassar Z., A History of Music and Singing on Egyptian Radio and Television [in:] Music and Media in the Arab World, ed. M. Frishkopf, Cairo, New York 2010.

Sa'ūdī A., Al-Id̄ā'a al-mișriyya .. šāhid 'alà tārīh Maṣr, AlHay'a al-'āmma li-1-isti'lāmāt. State Information Service, https://www.sis.gov.eg/Story/182829/\%D8\%A 7\%D9\% 84\%D 8\%A 5\%D 8\%B0\%D 8\%A 7\%D8\%B9\%D 8 \%A9-\%D8\%A7\%D9\%84\%D9\%85\%D8\%B5\%D8\%B1\%D9 \%8A\%D8\%A9-..-\%D8\%B4\%D8\%A7\%D9\%87\%D8\%AF-\% D 8\%B 9\% D 9\% 84\% D9\% 89-\% D 8\%A A \% D 8\% A 7\% 
D8\%B1\%D9\%8A\%D 8\%AE-\%D9\%85\%D8\%B5\%D 8\% B1?lang=ar.

Ug̉niyyat "Tahyā Maṣrr" ginā’ Madhat Șālih wa-Rihām 'Abd al-Hakìm wa-May Fārūq, Youtube, https://www.youtube.com/watch?v=raib33q7VU4.

Ug̉niyyat Tahyā Maṣr li-Aḥmad Šìba, Youtube, https://www. youtube.com/watch?v=LxfbOvH8zjg\&list=RDLxfbOvH 8zjg\&start_radio $=1$.

What is Shaabi?, http://www.aswandancers.org, http:// www.aswandancers.org/shaabi-history.

Wì ramadān 2020 / Tãmir Husnī \# Al-Aṣl_mașrī, Youtube,

https://www.youtube.com/watch?v=HLnkVkrsvxM. Wolny-Abouelwafa E., Pride in History - Particularly Pharaonic - in Contemporary Egyptian Songs as a part of Shaping National Identity, [in:] EGYPT YESTERDAY AND TODAY. Between Tradition and Modernity, eds. K. Myśliwiec, K. Pachniak, K. Nabożna, E. WolnyAbouelwafa, Warsaw 2019.

Wypych B., O nieintencjonalności w muzyce popularnej, [in:]

Sztuka i Polityka. Muzyka popularna, eds. M. Jeziński, Ł. Wojtkowski, Torun 2012.

2018 year of Persons with disabilities, Al-Hay'a al- 'āmma li-l-isti 'lāmāt. State Information Service, https://www. sis.gov.eg/Story/142865/2018-year-of-Persons-withdisabilities?lang=en-us.

\section{Abstract}

Egyptian patriotic songs are available in Egypt all the time and everywhere. Their frequency increases when the country faces problems. It is crucial to research this aspect of art to understand what kind of messages the artists send to society and - accordingly - their vision 
of homeland. The role of music is much of the time unrecognized. However, this article shows that it can play a big part in creating or strengthening patriotic feelings, especially in such a populous country as Egypt.

The author of the article analyzed three video clips of patriotic songs. Two of them were released in 2018 and have the same title Tahya Masr ("Long live Egypt"). The third one, Al-Aṣl mașri ("The Origin is Egyptian"), was released in 2020. They represent different genres of music. In the article, two main research questions are posed - about the image of the Egyptian society presented in the video clips and how much it is compatible with reality.

Based on the analysis of the lyrics of the songs and their video clips, the vision of society will be presented, and the popular motifs available generally in Egyptian patriotic songs will be highlighted. The examples of the images from the video clips will be shown by placing screenshots from each of the analyzed materials.

Keywords: Egypt, patriotic songs, Tahyā Maṣr, Egyptian army, national unity, Muslims, Christians, Pharaonic Egypt

\section{Abstrakt}

Egipskie pieśni patriotyczne można usłyszeć w Egipcie wszędzie i o każdej porze. Częstotliwość ich emisji dodatkowo wzrasta, gdy państwo boryka się z problemami. Ważne jest zatem podjęcie studiów nad tym zagadnieniem, aby lepiej zrozumieć, jaki rodzaj przekazu starają się przekazać społeczeństwu artyści, którzy komponują rzeczone piosenki, a dzięki temu odkryć ich wizję swojej ojczyzny. Znaczenie muzyki jest często niedoceniane. Jednakże niniejsza praca pokazuje, że może ona odgrywać znaczącą rolę w kreowaniu lub wzmacnianiu postaw patriotycznych, zwłaszcza w tak gęsto zaludnionym kraju, jakim jest Egipt.

Autorka badania poddała analizie trzy teledyski pieśni patriotycznych. Dwie z nich skomponowano i opublikowano w 2018 r. - noszą ten sam tytuł: Tahya Masr ("Niech żyje Egipt"). Trzecia, pt. Al-Așl mașrī („Korzenie są egipskie”), została opublikowana w 2020 r. Każda $\mathrm{z}$ nich należy do innego gatunku muzyki. W pracy postawiono dwa pytania badawcze - o obraz egipskiego społeczeństwa zaprezentowany w teledyskach oraz o to, w jakim stopniu jest on spójny z rzeczywistością. 
Na podstawie analizy słów piosenek patriotycznych i ich teledysków dokonano rekonstrukcji promowanego obrazu społeczeństwa oraz popularnych motywów. Materiał z teledysków został zobrazowany za pomocą zrzutów ekranu i poddany analizie za pomocą osobnej techniki badawczej.

Słowa kluczowe: Egipt, pieśni patriotyczne, Tahyā Maṣr, egipska armia, jedność narodowa, muzułmanie, chrześcijanie, Starożytny Egipt 


\section{Magdalena Kubarek \\ University of Warsaw \\ ORCID ID: https://orcid.org/0000-0002-6007-7363}

\section{Critical Representation of the Present in the Historical Novel in Egypt: Selected Aspects}

It is worth noting that historical narratives of varying degrees of fictionalization have a rich tradition in Arabic literature, and the fluid boundaries between history and literature often are indicated ${ }^{1}$. However, historical novels in the traditional sense of the term, i.e., a genre canonized thanks to Walter Scott, were initiated in Arabic literature by Christians $^{2}$. Ğūrǧĩ Zaydān (1861-1914), the author of 22 novels, the plot of which took place from the jahiliyah to the beginning of the $20^{\text {th }}$ century, is considered to be the pioneer of the genre. Some critics believe that Salìm al-Bustānì (died in 1884) was the first to publish historical novels such as $A l$ -Huyām fĩ futūḥ Aš-Šàm (Love in the time of the conquest of Syria), Al-Iskandar (Male name), Zanūbiyā (Female name),

1 Similarly, in Arabic, the root RWY produces both the history and story: rawà (the verb) is to tell, relate, report, give an account of; rāwin (the active participle from the same root) means a transmitter, relater, narrator, storyteller; and riwāya (the verbal noun from the same root) signifies a narrative, report, account, story, novel. S. Mehrez, Egyptian Writers between History and Fiction, Cairo-New York 1994, pp. 2-3.

2 Qāsim 'Abduh Qāsim emphasizes that the heyday of historical novel in Arabic literature has its source in the native tradition, and is not a result of Western inspiration, as some scholars think. Q.A. Qāsim, Ar-Riwāya at-tarīhiyya al-'arabiyya. 'Aṣr al-Izdihār, http://www.dar-ein. com [access: 31.10 .2020$]$. 
which he did in $1871-1874^{3}$. Nevertheless, already in the oeuvre of Ğūrğì Zaydān, that is from the very beginnings of historical novels as a genre, one can observe a tendency that fully comes to the fore in later years, along with the development of Arabic literature. Namely, Egyptian, and more broadly also Arab writers, undertake the task of presenting current problems and religious, social, and political ideas to the readers through the prism of this genre ${ }^{4}$.

The following article focuses on four writers whose works constitute a certain representation of the clashing trends and currents. A common platform for reflection is that each of the analyzed authors used historical topics to pursue specific ideological, didactic, or educational goals, apart from purely artistic ones. According to the postulate of Mikhail Bakhtin, literature's content reflects the whole of this ideological horizon of which it is itself a part ${ }^{5}$. The artist is able to penetrate the social laboratory and participate in the process of its formation. The following article attempts to show, based on selected examples, that since its incep-

3 'A. Al-Ašmāwī, Waqfa ma'a Ğūrǧ̀ Zaydān, Riyadh 1994, p. 6. More information on the development of Arabic historical novel can be found in: A. Roger, The Arabic Novel and History, [in:] The Oxford Handbook of Arabic Novelistic Traditions, ed. W.S. Hassan, Oxford 2017, pp. 49-66; idem, Literary History and the Arabic Novel, "World Literature Today" 2001, vol. 75, no. 2, pp. 205-213; B. Rayhanova, The Past and Present in the Modern Arabic Novel, "Zeitschrift der Deutschen Morgenländischen Gesellschaft” 2004, vol. 154, no. 1, pp. 71-84; M. Šawqat, Al-Fann al-qașaṣi fì al-adab al'arabī al-hadìt, Al-Qāhira 1963; Q.A. Qāsim, Ar-Riwāya at-ta'rīhiyya fī al-adab al-'arabi al-ḥadīt, Al-Qāhira 1979.

4 'A. Al-Ašmāwī, op. cit., p. 5.

5 A. Radomski, Sztuka jako źródto do badania historii. Czy historiografia jest sztuka (na przyktadzie literatury), "Kultura i historia" 2001, no. 2, http://www.kulturaihistoria.umcs.lublin.pl/archives/37 [access: 30.09.2020]. In turn, Baian Rayhanova draws attention to the possibility of analyzing the Arab historical novel in the context of Mikhail Bakhtin's concept of the chronotope. Baian Rayhanova, op. cit., p. 72. 
tion, the historical novel in the Arab world has been part of a broader historical discourse. On the other hand, thanks to the popularity obtained due to the combination of the Arab narrative tradition with the European literary canons, it became an important factor shaping the historical memory of contemporary Arabs.

The first of the four writers is Ğūrğī Zaydān, whose pioneering works were mentioned above ${ }^{6}$. He was born in Beirut in 1961 to a Christian family, interrupted his school education, but eventually managed to start medicine at the American University. He emigrated from Cairo, where he took up journalism, translation, and writing (initially, he was writing for the "Al-Muqtataf" journal, and in 1892 he founded his own - "Al-Hiläl"). He worked as a translator during the military campaign in Sudan, then returned to Beirut to study Semitic languages, but eventually settled back in Cairo. Before his death in 1914, he made numerous journeys, among others, to Europe. Ǧūrğĩ Zaydān, like many Lebanese and pioneers of the Arab Renaissance, was a well-traveled polyglot, fluent in Arabic, Aramaic, English, and French. As an erudite and specialist in the history of the Arab world and the history of Arabic literature, he published numerous monographs on the history of Islam, Arabic literature and language: including the five-volume study Ta'rìh at-tamaddun al-islāmī (History of Islamic Civilization, 1902) and Ta'rìh al-lugia al-'arabiyya (History of the Arabic Language, 1904).

He published 22 novels, 18 out of which belong to the Riwāyāt ta'rīh al-islām series (Novels of Islamic History). The first one was Armānūsa al-mișriyya (Egyptian Arm-

6 For more information on the life and output of Ǧūrǧĩ Zaydān see: T. Philipp, Ǧurğı̌ Zaidān: His Life and Thought, Beirut 1979. 
anusa, 1895), which tells the story of the conquest of Egypt by the Arabs under the leadership of 'Amr Ibn al-Āṣ. The protagonist, Armānūsa, is the daughter of Cyrus, Patriarch of Alexandria and viceroy of Emperor Heraclius in Egypt, and the fiancée of the emperor's son. The success of the first novel was undoubtedly an incentive to continue the historical series. Two years later, a large two-volume novel Fatāt Gassān (The Ghassanid Girl) was released. It is set in the period of the rise of Islam, during the time of the Prophet and the first two Rightly Guided Caliphs. The author discusses the subject of the formation of a new sociolegal order based on the values and principles of the new religion and the clash of these values with the old Bedouin customs and the conquest of Syria and Iraq. In this novel, Ğūrōi Zaydān laid out his views on the history of Arabs, the development of religious and legal ideology, and Arab statehood, which are a further starting point for subsequent novels. His later works, published every year, take place in successive historical periods in various centers of the ArabMuslim civilization, from Fergana in the East through Baghdad and Cairo to Andalusia in the West ${ }^{7}$.

7 Novels which belong to the Riwāyāt ta'rīh al-islām series: Armānūsah al-miṣriyyah (Egyptian Armanusa, 1895); Fatāt Gassān (Girls of Ghassan, 1897), 'Adrā' Qurayš (The Virgin of Quraysh, 1899); As-Sābi'

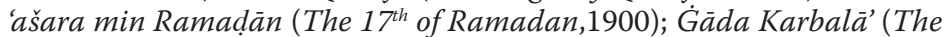
Heroin of Karbala, 1901); Al-Hağğăğ Ibn Yüsuf )Male name, [Umayyad Governor of Iraq], 1902); Fath Al-Andalus (The Conquest of Andalusia, 1903); Šārl wa-'Abd ar-Rahmān (Charles [Martel] and Abd al-Rahman, 1904); Abū Muslim Al-Hurāsānī (Male name, 1905); Al-'Abbāsa Uht arRašìd ('Abbasa, the Sister of Al-Rashid, 1906); Al-Aminn wa-l-Ma'mūn (AlAmin and Al-Mamun [The Sons of Al-Rashid], 1907); 'Arūs Farg̈āna (The Bride of Fergana, 1908); Aḥmad Ibn Tülūn (Male name, [The founder of the Tulunid dynasty], 1909); 'Abd ar-Rahmān an-Nāṣir (Male Name, [The Emir and Caliph of the Umayyad dynasty in Andalusia], 1910); Al-Inqlāb al-'Uțmānì (Young Turk Revolution, 1911); Fatāt al-Qayrawān (The Girl 
Although the novel Al-Inqlāb al-'Uțmānì (Young Turk Revolution, 1911) describes a coup in Istanbul in 1908, i.e., refers to the times of Ǧürğì Zaydān, it is included by 'Abd arRaḥmān Al-'Ašmāwī to the series "Novels from Islamic History". However, the researcher does not include to the series the three novels describing the history of Egypt in the $18^{\text {th }}$ and $19^{\text {th }}$ centuries: Al-Mamlūk aš-šărid (Runaway Mamluk, 1891), which takes place during the reign of Muhammad' Ali in Egypt (1805-1849), Asir al-Mutamahdì (Mahdi's Prisoner of War, 1892), which describes the opening of the Suez Canal, the 'Urabì Revolt and the Mahdist War in Sudan. The third novel, Istibdād al-Mamālìk (Tyranny of Mamluks, 1893), takes place in the $18^{\text {th }}$ century, during the reign of 'Alì Bayk al-Kabìr, (1728-1773) in Egypt and Syria. The author presents Egypt's political and social problems under the Mamluks against the background of the historical events. In turn, the novel Ğihäd al-Muhibbin (The Fight of Lovers) raises socio-moral themes and is described as didactic with a love theme.

Contemporary Arab critics accuse Ğūrōĩ Zaydān of creating a false picture of the history of Islam. Their first argument is that he wrote from a Christian perspective. The second one is that he was influenced by Western views on the history of Muslim civilization. The writer is also criticized for concentrating on "the most dramatic" periods in the history of Islam in his novels when the Arab-Muslim civilization was shaken by internal struggles and was experiencing crises while skipping periods of glory and heyday. In addition, he is accused of inaccuracies or conscious falsification

of Kairouan, 1912); Șalāh ad-Dīn wa-makäì al-haššăšìn (Saladin and the Assassins' tricks, 1913); Šağarat ad-durr (The Tree of Pearls, [Female name], 1914). 
of history ${ }^{8}$. In terms of the form, the Ǧūrǧi Zaydān's novels exhibit schematism and shortcomings in compositions. The author focuses more on the description of historical facts than on the fictional layer of the work. The first constitutes the foundation for presenting his religious-philosophical or socio-political views, instructions, or critical remarks 9 . The protagonists are often historical figures, whereas the fictional characters and side motifs are only briefly outlined.

Despite the criticism, Ǧūrğì Zaydāna's novels have had numerous editions in Arabic and have been translated into Indonesian, Turkish, Urdu, French, German and English, among others. The US-based Zaidan Foundation sponsors the research and translation of the legacy of the literary pioneer of the historical novel ${ }^{10}$. In the Eastern European background, references to Ğūrǒĩ Zaydān can already be found in the works of Ignaty Krachkovsky (one of the founders of the Soviet school of Arab studies, 1883-951) ${ }^{11}$. In the Pol-

8 For the criticism of Ğūrǒi Zaydān's negative presentation of history of Islam see 'A. Al-'Ašmāwī, op.cit.; Š. Abū Halīl, Ğ̉ūrğ Zaydān fī al-mizzān, Damascus 1981.

9 Hilmī Muhammad al-Qāāùd applies the term riwāya at-ta'lìm (didactic novel) to describe the novels by Ğürği Zaydān. In the next stage of development of Arabic literature, he distinguishes two more types of the genre: riwäya an-nad̆g (mature novel) and riwāya istid'à' at-ta'rīh (novel recalling the history). H.M. al-Qā'ùd, Ar-Riwāya at-ta'rīhiyya fì adabina al-hadìt. Dirāsa tațbiqiyya, Desouk 2010, pp. 7-8.

10 The Foundation published two monographs: T. Philipp, Jurji Zaidan and the Foundations of Arab Nationalism, New York 2014; G.C. Zaidan, T. Philipp (eds.), Jurji Zaidan's Contributions to Modern Arab Thought and Literature, Washington 2013. Moreover, it also sponsored English translations of five novels by Zaydān, which were made by prominent experts in Arabic literature, http://zaidanfoundation.org/ZF_Website_AboutFoundation.html [access: 30.09.2020].

11 I. Krachkovskiy, Избранные сочинения, vol. III, Moscow 1955-1960, pp. 19-46; E.G. Arasly, Ажирджи Зейдан и арабский исторический роман, Moscow 1967. 
ish context, Józef Bielawski (one of the founders of Arabic studies in Poland, 1910-1997) described Lebanese's works in the history of Arabic literature he edited in 1978. Since then, Polish academics specialized in Arabic literature have not paid much attention to Ğūrği Zaydān's writings.

Also, the next series of historical novels evokes controversy over the ideological commitment of its author. Nağīb al-Kaylānī (1931-1995) is considered the father of the "Islamic novel" and the first to formulate theoretical assumptions for a new genre called al-adab al-islāmì (Islamic literature). The popularization of religiously involved literature is linked with the activity of the Muslim Brothers, an organization founded by Hasan al-Bannā in Egypt in $1928^{12}$. Al-Bannā reformulated the traditional interpretation of mission ( $a d-d a$ 'wa): "With Al-Bannā's activity (...), the term began to denote active missionary work based on religious propaganda and conversion to Islam"13. With its main ideologue Sayyid Qutb (1906-1966) and his brother Muhammad (1919-2014), the subsequent leaders of this movement began propagating the idea of using art, including literature as an efficient tool of missionary work. However, it was not until the 1980s that literature described as "Islamic" (al-adab al-islāmī) became popular. At present, this term encompasses poetry, prose, and drama. However, readers are mostly interested in prose represented by the novel (riwāya) and short story (qisșsa), i.e., genres adopted from Western Europe in the $19^{\text {th }}$ and $20^{\text {th }}$ centuries $^{14}$.

12 A. Mrozek-Dumanowska, Islam i jego odnowa, Warsaw 2001, p. 62; W. Grabowski, Fundamentalizm muzułmański na Bliskim Wschodzie, Gdańsk 2013, pp. 32-38.

13 A. Mrozek-Dumanowska, op.cit., s. 60.

14 For more on this topic, see: M.M. Dziekan, Die islamische Lit- 
Undoubtedly, the literary theories and the works of Nağīb al-Kaylānī were influenced by the ideas of Quṭbs' brothers. The writer was born in the village of Šaršaba in Western Egypt. In 1951 he entered the Medicine Department of Cairo University, and after graduation, he started working as a doctor. Already in his early youth - in 1948 - he encountered the Muslim Brotherhood's ideas. After Al-Kaylānī had begun university education, he started attending the Muslim Brotherhood's lectures and engaged in their activities. Following a 1954 Muslim Brotherhood-led failed attempt on President Nasser's life, there was a wave of arrests. Initially, Al-Kaylānī helped provide aid to prisoners, but a year later, he was arrested, brought to court, and sentenced to ten years in prison for being a member of a secret armed organization. After three years, in 1958, he was released due to ill health. Arrested again in 1965, he was incarcerated for another two years. He was released following the events after the defeat of Egypt in the Six-Day War ${ }^{15}$.

erathurteorie und-kritik von 'Imäd ad-Dīn Halīl. Ein Vergleichendes Studium, "Rocznik Orientalistyczny" 2009, vol. 62, no. 2, pp. 15-25; M. Kubarek, Wspótczesna literatura muzutmańska w krajach arabskich, "Litteraria Copernicana" 2014, no. 13, pp. 39-53; idem, "Umar pojawia się w Jerozolimie": pamięć historyczna a ideologia, "Przegląd Orientalistyczny" 2016, vol. 257-258, no. 1-2, pp. 117-129; idem, Should the culture be engaged? Modern Islamic literature and its religious and political engagement, "International Journal of Culture and History" 2016, vol. 2, no. 1, pp. 54-58; idem, Paraenetic character of Islamic prose, "Comparative Literature in Education and Research" 2016, vol. 3, no. 1, pp. 1-10; idem, In search of an Identity: Modern Islamic Literature as an Ideological Confrontation between the East and West, [in:] Contacts and interaction. Proceedings of the $27^{\text {th }}$ Congress of the Union Européenne des Arabisants et Islamisants Helsinki 2014. Seria "Orientalia Lovaniensia Anale" №254, eds. J. Hämeen-Anttila, P. Koskikallio, I. Lindstedt, Leuven - Paris - Bristol 2017, pp. 261-271.

15 'A. Al-Arīnī, Al-Ittiǧāh al-islāmī fì a'māl Nağīb al-Kaylānī al-qașașiyya, Riyadh 2005, pp. 14-15. 
However, all this persecution made Al-Kaylānī stay faithful to his beliefs. In 1968 he left for the Gulf countries to return to his homeland only three years before his death in 1995 .

Al-Kaylānī reached for such a tried and tested medium for propagating ideological matters as the historical novel to implement al-da'wa's assumptions. He did not conceal that the stimulus to create the historical series was a desire to polemize with a distorted vision of his famous predecessor Ğūrğī Zaydān. Hence, he writes novels that evoke the glorious moments of the Arab-Muslim civilization, starting with the rise of Islam: Qätil Hamza (Hamza's Killer) and Nür Alläh (The Light of God) - through the epoch of the Crusades and the Mamluks - Al-Yaum al-Maw'ūd (Promised Day) - to the period of Napoleon's expedition to Egypt - Mawākib al-Ahrār (The Parade of Free People). They take up the subject of the ummah, which must heroically face a threat represented by hostile ideologies: imperialism, communism, Zionism. Some of them refer to events that are distant in time, e.g., An-Nidä' al-hälid (The Eternal (all), which takes place during the 1919 revolution in Egypt, Layālì Turkistān (The Nights of Turkestan) - taking place in Communist-led Turkestan after 1918 or Al-Zill alaswad (Black Shadow), whose hero Lij Iyasu, the ruler of Ethiopia from 1913 to 1916 was removed from power due to his favorable treatment of Muslims.

Other novels are a commentary to current events, e.g., $F \bar{l}$ az-zulàm (In the Shadow) - Egypt just before the 1952 revolution, Rihla ilä Allāh (Journey to the God) - persecution of the Muslim Brothers after the assassination of president Nasser, 'Ad ${ }^{2} \bar{a}$ ' Ğākartā (Virgin of Jakarta) - a communist coup in Indonesia in 1965, 'Amāliqat aš-šamāl (Giants of the North) - Nigeria during the 1965-1970 coup. However, 
regardless of how distant the historical perspective is, the author intends that the novels show a true version of the history of Islamic civilization, both the old and the latest. They present the history of Islam following the spirit of this religion and its values, although not without emotional commitment, which makes it even more credible and true ${ }^{16}$.

Bassam Tibi, who draws attention to the utilization of history by fundamentalist ideologies, believes that Muslim fundamentalism incorrectly presents many new concepts as a historical tradition. According to the researcher, fundamentalists create visions of their own and other civilizations for ideological purposes and then incorporate them into their tradition sustained by historical memory. The traditions revived by fundamentalists do not reflect the past but the contemporary ideas. Tibi describes this as "invention of tradition"17, applying a term coined by Eric Hobsbawm.

Al-Kaylānī himself believed that history serves to face contemporary problems of the ummah ${ }^{18}$. When analyzing his works from this angle, it should be emphasized that its overarching goal was to propagate pan-Islamic ideas and to

16 In the television program Ta'rīhuna fì al-mīzān (Our History on the Scales) broadcast by the station Ar-Risāla (Mission), the host, Taariq as-Suwaydān, deals with the misrepresentation of Islamic history. He mentions Nağìb al-Kaylānī, as an example of a writer who does not falsify the image of history, while he unequivocally criticizes the novels of Ğūrǧĩ Zaydān as too distant from historical truth and discusses inaccuracies and distortions in individual works of the Lebanese. The station, founded in 2006, belongs to the Rotana Media Group owned by a Saudi businessman, Al-Walīd Ibn Țalāl Ibn 'Abd al-'Azīz as-Su'ud, http://www. aljazeera.net/news/arabic/2013/8/17/ [access: 30.09.2020].

17 B. Tibi, Islam i polityka. Islam polityczny oraz fundamentalizm muzułmański, "Bliski Wschód. Społeczeństwo - polityka - tradycje" 2004, vol. 1, no. 1, p. 25.

18 'A. Salāma, Ar-Riwāya at-ta'rīhiyya 'anda Naǧīb al-Kaylāni, an unpublished thesis written in 2004 at Al-Azhar University, Cairo, p. 13. 
build and strengthen the sense of unity. Setting the plot in various Muslim countries: China, Ethiopia, Nigeria, Bosnia and Herzegovina, and Indonesia, makes the author's message universal. Recalling glorious moments from the history of Islam, on the one hand, serves to create a space of common memory, which constitutes the roots of a modern Muslim identity. On the other, it creates patterns of desirable behaviors and attitudes.

As in the case of the pioneer novels of Ğürği Zaydān, created in the late $19^{\text {th }}$ and early $20^{\text {th }}$ century, the form in AlKaylānīs novels was subordinated to utilitarian purposes. In his stories of the heroic deeds of Muslims, the author combines the tradition of the Arabic epos with the European adventure novel. Like in the case of Ğūrği Zaydān, the love theme forms the backbone of the novel, and a schematically conducted plot has a predictable ending: after many adventures, despite numerous intrigues and deceptions, good Muslims overcome hostile forces. Nevertheless, Al-Kaylānī is still critically acclaimed for his simple but elegant style and a harmonious combination of fictitious and factual threads.

Summing up, it can be said that the works of Al-Kaylāni create a chronicle of the martyrdom of Muslim heroes who sacrifice their lives in the name of higher values, not only for God but also for their homeland, thus referring to the apologetic trend spread in many pieces of literature around the world. It is worth mentioning that Al-Kaylānī was criticized by some theoreticians of Muslim literature for combining the Muslim perspective with a nationalist one ${ }^{19}$.

History as a factor shaping the identity of modern Arabs also plays a vital role for a representative of the generation of

19 M.Ḥ. Barīgišš, Dirāsāt fī l-Qișṣa al-Islāmiyya al-Mu'āṣira, Beirut 1994, pp. 77-78. 
Egyptian writers debuting in the 1970s, Raḍà Ašūr (19462014) - the author of The Granada Trilogy (1994-1995) ${ }^{20}$ ranked among the 100 best literary works of the $20^{\text {th }}$ century by Arab Writers Union² ${ }^{21}$. Raḍà' Ašūr was also known as a human rights activist and university lecturer. She graduated from Comparative Literature Cairo University and completed her $\mathrm{PhD}$ at the University of Massachusetts, defending her dissertation on African-American literature. As the wife of the Palestinian Mouried al-Barghouti, who was deported from Egypt in 1977, she was politically involved in the Palestinian conflict for many years, criticizing the establishment of IsraeliEgyptian diplomatic relations under President Anwar Sadat.

Her oeuvre includes monographs and academic articles in the field of Arab and American literature and literary works. She is the author of the memoirs: Ar-Rihla. Ayyam țāliba miṣriyya fì Amrīkā (The Journey. Memoirs of an Egyptian Student in America, 1983), the autobiographical novel Atyāf (Specters, 1999), two collections of short stories Ra'aytu an-nahl (I Saw the Date Palms, 1990) Taqārìr as - sayyida Rä' (Mrs. Ra's Reports, 2001) and several novels: Hağar däfi' (Warm Stone, 1985) Hadiğa wa-Sawsan (Khadija and Sawsan, 1989), Sirāğ (Lamp, 1992), Tulatiyya Garnāṭa (The Granada Trilogy, 1994-1995), Qita'a min Ūrūbā (A Part of Europe, 2003), Farağ (Cheerfulness, 2008), Tanțūiyya (Tantourian Woman, 2010). She has been honored with numerous literary awards, the most important of which are the 2007 Constantine Cavafy Prize for Literature and the $2011 \mathrm{Al}$ Owais Award.

20 English translation: W. Granara, Granada: A Novel, New York 2003.

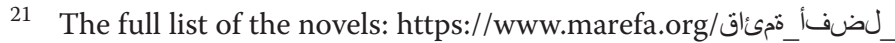

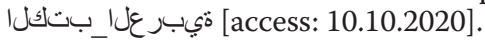


Her most famous work is The Granada Trilogy which won in 1994 the Best Book of the Year Award granted by the General Egyptian Book Organization and the first prize at the first Arab Women's Book Fair in 1995. It has been translated into various languages, including English and Spanish. The three-volume chronicle illustrates the gradual and deliberate elimination of Arab-Muslim culture in Spain against the background of the history of three generations of the Spanish Arab family, covering the period from 1491 to 1609 , i.e., from the fall of Granada to the total expulsion of Muslims from Andalusia.

Basing on the belief that the message of pessimism is immoral, 'Ašūr used her novels to resist and deal with failure. In The View from Within (edited by Ferial Ghazoul and Barbra Harlow, 1994), she described herself as "an Arab woman and a citizen of the Third World" ${ }^{22}$. In turn, in one of the interviews for The Guardian", she declared: "My heritage in both cases is stifled ... I write in self-defense and in defense of countless others with whom I identify or who are like me"23. Undoubtedly, Raḍà̀ Ašūr treated writing as a kind of gaining subjectivity, regaining causative power: "I write, the space becomes my own, and I am no longer an object acted upon by history, but a subject acting in history"24/ As Caroline Seymour-Jorn notes: "Writing is clearly a political and social act for 'Ašūr"

22 N.R. Elnahla, Radwa Ashour (1946-2014): A Literary, Cultural and Political Activist Icon, Echoing in Egypt's Valley, „Al Jadid” 2015, vol. 19, no. 68, https://www.aljadid.com/content/radwa-ashour-1946-2014 [access: 30.09.2020].

23 Ibidem.

24 Ibidem.

25 C. Seymour-Jorn, Teaching Arab Women's Literature. Radwa Ahour's Gharnāta, „Al-'Arabiyya” 2005-2006, vol. 38/39, p. 144. 
At the same time, 'Ašūr's writing is highly personal and emotional. In her novel, she uses heterogeneous narrative techniques and mixes individual and collective perspectives and female and male perspectives. Thanks to this narrative's strategy, the reader is a witness to the intimate experiences of individual members of the family, starting from the senior, the bookbinder Abū Ğa'far, through his wife and children and ending with their offspring ${ }^{26}$.

The fate of the family is a metaphor for the fate of a whole generation. However, the dynamics and ambivalence of the relations between the characters and the destructive impact of a long-term oppressive situation on the family and the individual are presented vividly. The author breaks with the romantic depiction of heroic resistance to organized political and religious oppression, focusing on the individual experience of violence and the relativization of values generated by war and occupation.

As an activist involved in initiatives aimed at putting pressure on the government of Egypt, Raḍwà' Ašūr believed that writing was also a type of activity that could have a tangible impact on society. According to her, writers participate in shaping the social and historical awareness of their countrymen. They communicate their vision of history, conditioned by their beliefs, the reality in which they live, as well as their relationship to a given historical period and culture. Therefore, each vision is a unique one. Also, finding her own language to communicate with readers was an essential part of 'Ašür's writing. It was connected with the necessity to dialogue with the masculine tradition of Arab literature, in which women played a marginal role. She tried to create

26 Ibidem, p. 148. 
within this tradition because breaking with it would risk losing communication with the reader - "tearing down the bridge" - as "Ašür called it ${ }^{27}$. This approach shows how important it was for her to reach the reader with her political and social message.

The last of the writers, Yūsuf Zaydān, is one of the novelists who made their debut in the first decade of the new millennium. Arab critics note that since the turn of the $20^{\text {th }}$ and the $21^{\text {st }}$ century, a revival of historical themes and a kind of historical narrative boom is a noticeable trend in Arabic literature, which led to the formation of a new subgenre called the "neohistorical novel". In the context of Egypt, it may be worthwhile to mention such writers as Bahā Țāhīr (b. 1935), Suna 'Allāh Ibrāhīm (b. 1937), Muhammad Mansī Qandīl (b. 1949), Salwà Bakr (b. 1949), Hišã al-Hुašin (b. 1963) and Aḥmad Murād (b. 1978). The growing number of historical works confirms the importance and popularity of this new literary trend. Fife out of the novels that have received the prestigious International Prize for Arabic Fiction since 2008 are historical novels, so quite a $\operatorname{lot}^{28}$. Also in 2020, the award

27 Ibidem, pp. 145-146.

28 A similar trend is noticeable in the world literature since the end of the $20^{\text {th }}$ century: "The relationship between the past and the present as it is mediated by the literary text is now being constituted and assessed in new and innovative ways both within the academy and the public sphere. The public interest, and esteem accorded to historical fiction is reflected in bestseller lists and literary prizes - most notable, perhaps, is the dominance of historical fiction in Man Booker and Orange Prize short lists, and the establishment of the Walter Scott Prize for historical fiction in 2010 - while the extent of academic interest is demonstrated by the number of recent monographs that reassess historical fiction within discrete literary periods. K. Mitchell, N. Parson, Reading the Represent Past: History and Fiction from 1700 to the Present, [in:] Reading Historical Fiction. The Revenant and Remembered Past, eds. K. Mitchell, N. Parson, London 2013, p. 1. 
went to the historical novel The Ad-Diwan al-Isbārți (The Spartan Court) by Algerian writer 'Abd al-Wahhāb 'Īsāwī. In 2009, the prize was awarded to 'Azāzill (Azazel, 2008) by Yūsuf Zaydān.

Zaydān, born in 1958, is a researcher in the field of philosophy and history of Islam, with a special predilection for old manuscripts ${ }^{29}$. For many years, he was the Manuscript Centre and Museum director affiliated to the Bibliotheca Alexandrina and published many scholarly works. However, only after the publication of the novel 'Azāzill (Azazel, 2008), he became one of the most recognizable figures in Egypt's intellectual life, and his work became the subject of academic analysis ${ }^{30}$. His statements (often very controversial) and speeches disseminated by the media are an important element of public debate about the condition of modern Egypt.

The novel Azazel chronicles the difficult period of crystallization of Christian doctrine and the disputes between the Council of Nice (325) and the Council of Ephesus (431). It met

29 Information to be found on the author's website: http://www.ziedan.com/CV/12.asp [access: 25.10.2020].

30 M. Saba, Azazeel and the Politics of Historical Fiction in Egypt, “Comparative Literature" 2013, vol. 65, no. 3, pp. 265-284; A. Abu Baker, The Problematics of Identity and Identity Erasure in Yossef Ziedan's Azazeel, "Journal of Arts and Humanities" 2015, vol. 4, no. 12, pp. 37-49; M.S. AlMostafa, The Representation of Women in Youssef Ziedan's Azazeel: A Feminist Study, "Journal of Arts and Humanities" 2016, vol. 5 no. 3, pp. 38-49; M. Kubarek, Religion and Power in the Novel 'Azāzīl by Yusūf Zaydān, [in]: Bliski Wschód w procesie przemian, eds. A. Bryc, M. Lewicka, M. Dahl, vol. 2, Toruń 2015, pp. 109-121; idem, Meandry wspólnotowego i jednostkowego losu. Wyznaczanie i przekraczanie granic w prozie Yüsufa Zaydāna, [in:] Granice i pogranicza w perspektywie orientalistycznej, eds. A. Bednarczyk, M. Kubarek, M. Szatkowski, Kraków 2017, pp. 209-221; idem, Religia $i$ społeczeństwo w prozie Jusufa Zajdana, [in:] Literatury Azji i Afryki wobec problemów wspótczesności, Materiaty XXXV Zjazdu Orientalistów Polskich, Warszawa, 16-17 XI 2015, eds. M.M. Dziekan, A. Bareja-Starzyńska, Warsaw 2016, pp. 131-144. 
with the disapproval of the Coptic Church in Egypt right after it came out. The work is a diary consisting of notes on scrolls made by a monk Hypa (Hïbā), accidentally found during archaeological excavations in Syria near Aleppo. The form, stylized as a documentary, was one of the reasons for the church's attacks, which the writer refuted by stating that his book is literary fiction and not a historical work, and the formula adopted is an artistic procedure and not a falsification.

On the wave of popularity of 'Azāzìl in 2010, Yūsuf Zaydān published a novel, entitled $A n$-Nabați (Nabatean), which takes place in the years right before the Arab-Muslim troops led by 'Amr Ibn al-Āṣ entered Egypt. The protagonist is a young Christian woman, Maria, from a small Nile Delta village, lying on a trade route leading from the Arabian Peninsula to the North. It is an era in which Egypt was about to undergo another profound transformation. After the period of Christianization and the schism, which resulted in the formation of the Monophysite Church, a new religion appeared on the horizon. It was to shape the face of the country in the following centuries. In 2012, Zaydān began the publication of the trilogy Muhāl (Impossible, 2012), Guwwantanāmù (Guantanamo, 2014) and Nür (Female name, 2016), which shows the complicated fate of a young Sudanese caught up in political turmoil at the turn of the second and third millennium that constitutes a metaphor for the fate of the entire generation. The last novel by Zaydān, Fardaqān. I'tqāl aš-šayh ar-ra'īs (Fardakan Fortress. The Imprisonment of the Great Sheikh) released in 2018 is also a historical one.

The canvas of Zaydān's historical novels became an opportunity for the author to present his historiosophical concepts and analyze the causes of the current weakness of the 
Muslim world. According to the writer, the contemporary Egyptian state and its inhabitants are heirs to the Pharaonic, Hellenistic, Nubian, Christian, and Arab-Muslim civilizations. We observe the same phenomenon in other countries in the Middle East whose present borders do not coincide with the historical, geographical, and cultural boundaries. The South of Egypt inhabited by Nubian people, Greek Alexandria, Aramaic Jerusalem, or Nabataean Aleppo, presented in the novels of Zaydān, are worlds where different languages resonate, whose inhabitants bow to different gods and worship different customs. However, they all form a community of a place, which depends largely on the political situation, and where periods of tolerance alternate with periods of persecution. Yūsuf Zaydān sees the key to comprehending the present in understanding the past and is certainly not isolated in his views.

To sum up, it should be stated that the work of the three Egyptian writers, coming from different generations and backgrounds, is largely representative of the tendencies determining the development of historical novels in Egypt as well as in the Arab world. On the one hand, this genre is treated as a convenient medium of ideological content and serves propaganda or didactic purposes. On the other hand, it is a significant voice of artistic expression, encompassing many styles, an abundance of inspirations, and a plethora of cultural contexts. In this context, it does not come as a surprise that Arab critics define the goals of the writer of historical novels as follows: to teach about history, to familiarize with the heritage, and to revive its glory by presenting it in a vivid literary form, or to deal with the problems of the present through the prism of a bygone era ${ }^{31}$.

31 Š. As-Sayyid, Ittiğahāt ar-riwāya al-'arabiyya fī Mișr, Cairo 1996, p. 77. 
Not without significance is the existence of political and religious censorship in the Arab world, which forces the writers to critically refer to contemporary phenomena, speaking through the mask of the past. This commitment and sense of mission continue to be a key factor determining the historical novel's development directions. As expressed by Sāmiya Mahraz: the "position of the writer as 'underground historian' is indeed what characterizes much of the literary output in the contemporary Arab Word"32. At the same time, the controversy aroused by each author's work is proof of the importance of history in the contemporary intellectual discourse as an important factor shaping the religious and national identity of contemporary Arabs. In conclusion, it should be emphasized that the revival of historical prose in Arabic literature once again puts the spotlight on the questions to which current answers should be sought.

\section{Bibliography}

Abu Baker A., The Problematics of Identity and Identity Erasure in Yossef Ziedan's Azazeel, "Journal of Arts and Humanities" 2015, vol. 4, no. 12.

Abū Halīil Š., Ğūrğğ Zaydān fĩ al-mīzān, Damascus 1981. al-Qā'ūd Ḥ.M., Ar-Riwāya at-ta'rīhiyya fĩ adabina al-hadìt. Dirāsa tațbiqiyya, Desouk 2010.

Al-'Arīnī‘ A., Al-Ittiğḡăh al-islāmī fì a'māl Nağīb al-Kaylānī al-qașașiyya, Riyadh 2005.

Al-'Ašmāwī 'A., Waqfa ma'a Ğūrǒ̀̃ Zaydān, Riyadh 1994. AlMostafa M.S., The Representation of Women in Youssef Ziedan's Azazeel: A Feminist Study, "Journal of Arts and Humanities" 2016, vol. 5, no. 3.

32 S. Mehrez, op.cit., p. 8. 
Arasly E.G., Ажирджи Зейдан и арабский исторический роман, Moscow 1967.

As-Sayyid Š., Ittiğahāt ar-riwāya al-'arabiyya fī Miṣr, Cairo 1996.

Barīgiš M.Ḥ., Dirāsāt fì l-Qiṣṣa al-Islāmiyya al-Mu'āṣira, Beirut 1994.

Elnahla N.R., Radwa Ashour (1946-2014): A Literary, Cultural and Political Activist Icon, Echoing in Egypt's Valley, "Al Jadid" 2015, vol. 19, no. 68, https://www.aljadid.com/ content/radwa-ashour-1946-2014.

Dziekan M.M., Die islamische Literathurteorie und -kritik von 'Imād ad-Din Halïl. Ein Vergleichendes Studium, "Rocznik Orientalistyczny" 2009, vol. 62, no. 2.

Granara W., Granada: A Novel, New York 2003.

Grabowski W., Fundamentalizm muzutmański na Bliskim Wschodzie, Gdańsk 2013.

Krachkovskiy I., Избраннье сочинения, vol. III, Moscow 1955-1960.

Kubarek M., Współczesna literatura muzutmańska w krajach arabskich, "Litteraria Copernicana" 2014, no. 13.

Kubarek M., "Umar pojawia się w Jerozolimie": pamięć historyczna a ideologia, "Przeglad Orientalistyczny" 2016, vol. 257-258, no. 1-2.

Kubarek M., Should the culture be engaged? Modern Islamic literature and its religious and political engagement, "International Journal of Culture and. History" 2016, vol. 2, no. 1 .

Kubarek M., Paraenetic character of Islamic prose, "Comparative Literature in Education and Research" 2016, vol. 3, no. 1 .

Kubarek M., In search of an Identity: Modern Islamic Literature as an Ideological Confrontation between the East 
and West, [in:] Contacts and interaction. Proceedings of the $27^{\text {th }}$ Congress of the Union Européenne des Arabisants et Islamisants Helsinki 2014. Seria "Orientalia Lovaniensia Anale” №254, eds. J. Hämeen-Anttila, P. Koskikallio, I. Lindstedt, Leuven-Paris-Bristol 2017.

Kubarek M., Religion and Power in the Novel 'Azāzill by Yusüf Zaydān, [in]: Bliski Wschód w procesie przemian, eds. A. Bryc, M. Lewicka, M. Dahl, vol. 2, Toruń 2015. Kubarek M., Meandry wspólnotowego i jednostkowego losu. Wyznaczanie i przekraczanie granic w prozie Yüsufa Zaydāna, [in:] Granice i pogranicza w perspektywie orientalistycznej, eds. A. Bednarczyk, M. Kubarek, M. Szatkowski, Kraków 2017.

Kubarek M., Religia i spoteczeństwo w prozie Jusufa Zajdana, [in:] Literatury Azji i Afryki wobec problemów wspótczesności, Materiaty XXXV Zjazdu Orientalistów Polskich, Warszawa, 16-17 XI 2015, eds. M.M. Dziekan, A. Bareja-Starzyńska, Warsaw 2016.

Mehrez S., Egyptian Writers between History and Fiction, Cairo-New York 1994.

Mitchell K., Parson N., Reading the Represent Past: History and Fiction from 1700 to the Present, [in:] Reading Historical Fiction. The Revenant and Remembered Past, eds. K. Mitchell, N. Parson, London 2013.

Mrozek-Dumanowska A., Islam i jego odnowa, Warsaw 2001.

Philipp T., Ğurğ̄ Zaidān: His Life and Thought, Beirut 1979. Philipp T., Jurji Zaidan and the Foundations of Arab Nationalism, New York 2014.

Qāsim Q. 'A., Ar-Riwāya at-tarīhiyya al-'arabiyya. 'Aṣr alIzdihār, http://www.dar-ein.com.

Radomski A., Sztuka jako źródto do badania historii. Czy 
historiografia jest sztuka (na przykładzie literatury)?, "Kultura i Historia" 2001, no. 2, http://www.kulturaihistoria.umcs.lublin.pl/archives/37.

Rayhanova B., The Past and Present in the Modern Arabic Novel, "Zeitschrift der Deutschen Morgenländischen Gesellschaft" 2004, vol. 154, no. 1.

Roger A., Literary History and the Arabic Novel, "World Literature Today" 2001, vol. 75, no. 2.

Roger A., The Arabic Novel and History, [in:] The Oxford Handbook of Arabic Novelistic Traditions, ed. W.S. Hassan, Oxford 2017.

Saba M., Azazeel and the Politics of Historical Fiction in Egypt, "Comparative Literature" 2013, vol. 65, no. 3.

Salāma' A., Ar-Riwāya at-ta'rīhiyya 'anda Nağìb al-Kaylāni, an unpublished thesis written in 2004 at Al-Azhar University, Cairo.

Šawqat M., Al-Fann al-qașași fì al-adab al'arabì al-ḥadìt, Al-Qāhira 1963.

Qāsim Q.A., Ar-Riwāya at-ta'rīhiyya fì al-adab al-'arabì alhadìt, Al-Qāhira 1979.

Seymour-Jorn C., Teaching Arab Women's Literature. Radwa Ahour's Gharnāța, “Al-'Arabiyya” 2005-2006, vol. 38/ /39.

Tibi B., Islam i polityka. Islam polityczny oraz fundamentalizm muzutmański [Islam and Politics. Political Islam and Islamic Fundamentalism], "Bliski Wschód. Społeczeństwo - polityka - tradycje” 2004, vol.1, no. 1.

Zaidan G.C., Philipp T. (eds.), Jurji Zaidan's Contributions to Modern Arab Thought and Literature, Washington 2013. 


\begin{abstract}
The paper deals with the historical novel issue, a genre born in Arabic literature at the turn of the $19^{\text {th }}$ and $20^{\text {th }}$ centuries and has enjoyed unflagging popularity ever since.

The material for the analysis will be the works of Egyptian writers: the pioneer of the genre, Guunrğī Zaydān Nağīb al-Kaylānī, the pioneer of Islamic literature and the representative of the middle generation born in the 1940s and 1950s Raḍwà 'Ašūr and Yūsuf Zaydān. Based on the analysis of selected works, the paper shows that authors who represent various views, ideologies, and literary currents, by undertaking ethical and political reflection, make a story about the past an efficient tool for a critical presentation of the present. Thus, the historical novel is an important element of the discourse conducted by Arab intellectuals, which aims to diagnose and define the most important problems of the Arab world.
\end{abstract}

Keywords: Arabic world, Egypt, Arabic literature, historical fiction, Islamic literature

\begin{abstract}
Abstrakt
Praca dotyczy powieści historycznych, gatunku literackiego powstałego w literaturze arabskiej na przełomie XIX i XX w., który od tamtej pory cieszy się dużą popularnością. Materiałem do badań są książki egipskich pisarzy, szczególnie pionierów gatunku: Ğūrğĩ Zaydān i Nağīb al-Kaylānī, oraz reprezentantów pokolenia z przełomu lat 40. i 50. XX w.: Raḍwà 'Ašūr i Yūsuf Zaydān. Na podstawie analizy wybranych dzieł praca dowodzi, że autorzy, którzy reprezentowali różne poglądy, ideologie i nurty literackie poprzez podjęcie refleksji etycznej i politycznej uczynili historię o przeszłości skutecznym narzędziem służącym do krytycznej oceny współczesności. Z tego powodu powieść historyczna jest ważnym elementem dyskursu arabskich intelektualistów, których celem jest zdiagnozowanie i zdefiniowanie najważniejszych problemów arabskiego świata.
\end{abstract}

Słowa kluczowe: arabski świat, Egipt, literaturę arabska, fikcja historyczna, literaturę islamska 